Review

\title{
Sub- and Supercritical Water Liquefaction of Kraft Lignin and Black Liquor Derived Lignin
}

\author{
Jukka Lappalainen ${ }^{1}{ }^{*}$, David Baudouin ${ }^{2}$, Ursel Hornung ${ }^{3}$, Julia Schuler ${ }^{3}$, Kristian Melin ${ }^{4}$, \\ Saša Bjelić ${ }^{2} \mathbb{D}$, Frédéric $\operatorname{Vogel}^{2}{ }^{\mathbb{D}}$, Jukka Konttinen ${ }^{1}$ and Tero Joronen ${ }^{1}$ \\ 1 Faculty of Engineering and Natural Sciences, Tampere University, 33720 Tampere, Finland; \\ jukka.konttinen@tuni.fi (J.K.); tero.joronen@tuni.fi (T.J.) \\ 2 Bioenergy and Catalysis Laboratory (LBK), Paul Scherrer Institute, 5232 Villigen, Switzerland; \\ david.baudouin@psi.ch (D.B.); sasa.bjelic@psi.ch (S.B.); frederic.vogel@psi.ch (F.V.) \\ 3 Karlsruhe Institute of Technology, Institute of Catalysis Research and Technology (IKFT), \\ 76344 Eggenstein-Leopoldshafen, Germany; ursel.hornung@kit.edu (U.H.); \\ schulerjulia88@googlemail.com (J.S.) \\ 4 VTT Technical Research Centre of Finland, 02150 Espoo, Finland; kristian.melin@vtt.fi \\ * Correspondence: jukka.lappalainen@tuni.fi
}

Received: 18 May 2020; Accepted: 19 June 2020; Published: 28 June 2020

check for updates

\begin{abstract}
To mitigate global warming, humankind has been forced to develop new efficient energy solutions based on renewable energy sources. Hydrothermal liquefaction (HTL) is a promising technology that can efficiently produce bio-oil from several biomass sources. The HTL process uses sub- or supercritical water for producing bio-oil, water-soluble organics, gaseous products and char. Black liquor mainly contains cooking chemicals (mainly alkali salts) lignin and the hemicellulose parts of the wood chips used for cellulose digestion. This review explores the effects of different process parameters, solvents and catalysts for the HTL of black liquor or black liquor-derived lignin. Using short residence times under near- or supercritical water conditions may improve both the quality and the quantity of the bio-oil yield. The quality and yield of bio-oil can be further improved by using solvents (e.g., phenol) and catalysts (e.g., alkali salts, zirconia). However, the solubility of alkali salts present in black liquor can lead to clogging problem in the HTL reactor and process tubes when approaching supercritical water conditions.
\end{abstract}

Keywords: hydrothermal liquefaction; black liquor; lignin from black liquor

\section{Introduction}

People's lifestyles are beginning to be severely affected by climate change and the continuous depletion of the world's limited supply of natural resources. The Intergovernmental Panel on Climate Change (IPCC) recently reported that exceeding the inevitable $1.5 \mathrm{~K}$ increase in global warming will have significant impacts on our planet, and is already leading to the extinction of various species of life on Earth [1]. Mitigating the pace and effects of global warming urgently requires strong global action in order to ensure a massive reduction in greenhouse gas (GHG) emissions.

One of the most effective ways to cut GHG emissions is to reduce emissions from motorized transport. The worldwide energy demand from transportation in 2016 was ca. $52 \mathrm{EJ}\left(1 \mathrm{EJ}=1 \times 10^{18} \mathrm{~J}\right)$ corresponding to $23 \%$ of the total global energy requirement for that year, and, therefore, accounting for around $23 \%$ of the total $\mathrm{CO}_{2}$ emissions [2,3]. Currently, the majority of transportation technologies is based on combustion engines powered by fossil fuels. One obvious way to reduce $\mathrm{CO}_{2}$ emissions in the transportation sector is to replace fossil fuels, either partly or even wholly, with renewable fuels. However, to do so will require massive changes in our transport infrastructure. One of the 
great advantages of biomass-based drop-in biofuels is that they do not require the complete renewal of a country's transport infrastructure, or even of a business' fleet of vehicles. Although biofuels are still relatively expensive compared to certain fossil fuel alternatives, they are already available and businesses can easily start to use them, so any new developments and research contributions to the technology of biofuel production is greatly to be desired.

The net photosynthetic production of biomass is around 220 billion dry tons, corresponding to an energy content of 4500 EJ [4]. In 2017, global energy demand was 588 EJ. Thus, theoretically, 13\% of the available biomass could fulfill the global energy needs of humankind [5]. However, in practice there are several limitations that restrict the full exploitation of the biomass potential. Aside from the economic considerations, there are the issues of sustainability and food production. It is estimated that the potential of biomass as an energy source is in between $100 \mathrm{EJ}$ and $1200 \mathrm{EJ}$ per year [6]. Estimates vary widely because different studies rely on different assumptions, such as population growth, the development of global food production and consumption, and the amount of available forest residues [6]. Forest residues contains biomass formed as a by-product of forestry and forest industry.

Hydrothermal liquefaction (HTL) is considered to be the most promising pathway for deriving sustainable biofuels, especially from wet feedstock with a moisture content of above $55 \mathrm{wt} . \%[7,8]$. Hydrothermal liquefaction uses water at high temperature and pressure to degrade biomass into smaller chemical compounds. The properties of water change drastically near critical conditions $\left(374{ }^{\circ} \mathrm{C}, 221 \mathrm{bar}\right)$. At supercritical conditions non-polar lignin compounds dissolve into water [7]. The most valuable product from the HTL process is bio-oil, but water-soluble organics (WSO), char, and gaseous products are also by-products of the process. The yield and composition of these fractions mainly depends on the reaction conditions, the residence time and the origin of the biomass. Under optimal conditions, the process can effectively produce bio-oil with high heating values, i.e., it has higher energy density and lower oxygen content than other biomass-based fuels, such as fast pyrolysis oil [9]. However, crude bio-oil needs to be upgraded and refined before it can meet the demands of our current transportation sector.

An important criterion for selecting an appropriate biomass source for renewable biofuel production is that it should not compete with food production. Therefore, the preferred input materials for the HTL process are waste and biomass side streams. This is where the wood processing industries come in, as they produce a large variety of non-edible by-products. In Kraft pulping, wood chips are treated with cooking chemicals, i.e., sodium sulfate and sodium hydroxide, which separate the cellulose pulp from the lignin and hemicellulose. Any dissolved organic compounds and cooking salts in the pulp fraction, which mainly contains cellulose, are separated out from the pulp in a washing process. The by-product of this process, i.e., black liquor, is then dried in an evaporator plant and burned in a recovery boiler. The cooking chemicals are recovered from the melt, and the steam generated in the boiler is used for process heating and/or electricity production in a steam turbine. State-of-the-art pulp mills produce more electricity than they consume. For instance, the new mega mill in Äänekoski (Finland) produces 2.4 times its own electricity needs [10]. The surplus electricity is sold on the electricity market. The difficulty with the electricity market is that the price fluctuates. Even though the pulp mill's electricity production is continuous and steady, the price they get for this electricity varies considerably depending on the season. In Nordic countries, which use an ever-increasing amount of renewable energy such as hydropower and wind power, most of the time the price of electricity is relatively low. In fact, for most of the time, the wood-pulp industry could achieve higher profits by converting the organics of black liquor into bio-products.

Hydrothermal liquefaction is an interesting candidate for such a conversion technology because it enables the wet biomass to be used directly, without the need for a drying phase thus saving money. A warm stream of black liquor separated from the middle of the evaporator plant improves the energy efficiency of the whole process. In addition, processing a proportion of the organics in the black liquor may also increase pulping capacity, as in many cases, the recovery boiler is a bottleneck in pulp mill processes [11]. Another benefit of applying HTL is that it is easy to return the cooking chemicals to the 
chemical recovery in the water phase, as the cooking chemicals are water soluble and remain in their aqueous phase.

The hydrothermal liquefaction of black liquor is thus currently under intense scientific and commercial scrutiny, and several companies have presented their own patented solutions for using its potential, such as Licella [12], RenFuel [13] and SunCarbon AB [14]. Licella's technology, called Cat-HTR ${ }^{\mathrm{TM}}$, uses a catalytic hydrothermal reactor to convert various biomasses into valuable products [15]. Radiata Pine and black liquor are mixed in the feedstock with the black liquor also working as a catalyst [16]. The feed is treated for $25 \mathrm{~min}$ in the reactor, which operates at ca. $603-628 \mathrm{~K}$ and 23.5-25 MPa [16]. Licella and a Canadian pulp company, Canfor Pulp in Prince George in British Columbia in Canada, have recently announced the construction of a commercial plant that will produce 500,000 barrels of biocrude annually [17]. RenFuel produces LIGNOL ${ }^{\circledR}{ }^{\circledR}$ oil from black liquor [18]. LIGNOL oil can be refined into bio-gasoline and biodiesel in a conventional refinery plant, after which it is blended with fossil fuels. Their technology is based on several unit operations, such as acid catalyst hydrolysis, hydrogenation and deoxygenation, degrading the lignin into smaller monomers [18]. SunCarbon uses membrane filtering to separate lignin from other light components of black liquor. The lignin is treated under subcritical water conditions [19]. The intermediate products are treated with acid and solvents to remove impurities, such as ash and other residues [19]. The resulting product is a biocrude, which can then be further upgraded into transportation fuel in an oil refinery. This membrane filtration process has been successfully demonstrated at SP Energy Technology Center in Piteå in Sweden, which is capable of extracting $1.5 \mathrm{~kg}$ of lignin per hour using this technique [20].

Although there have been numerous HTL studies of various feedstocks, no comprehensive review article has been published on the HTL of black liquor or of its derived products. Those HTL review articles that do exist either focus on the HTL of biomasses from different sources [21,22], the HTL of pure lignin compounds [23], or the HTL of a specific biomass, such as wood [24], algae [25-27], agricultural and forestry waste [28], and even swine manure [29]. In addition, Ramirez et al. [30] gathered studies on the quality and upgradability of bio-oil produced from lignocellulosic or algae biomass in the HTL process, and Castello et al. [22] investigated existing continuous HTL processes, where different types of biomass feeds are processed.

This study defines the current level of knowledge about the HTL of black liquor and identifies important gaps in the knowledge that should be explored in the future. Firstly, the black liquor is introduced in Section 2. Section 3 handles the most significant parameters of HTL, such as reaction condition and residence time, effect of inorganic salts and role of co-solvents and catalysts. Reaction chemistry, such as reaction pathways and kinetics, and effect of sulfur and bio-oil quality are investigated in Section 4. Techno-economic aspects are explored in Section 5. The review ends in conclusions in Section 6.

\section{Black Liquor}

Black liquor is a by-product of the Kraft pulp process, where lignocellulosic biomass is treated under alkaline conditions ( $\mathrm{pH}>12$ ) at a temperature range of between $433 \mathrm{~K}$ and $453 \mathrm{~K}$ for 0.5-3.0 $\mathrm{h}$ [31]. About 170 million dry tons of black liquor were produced in 2007, which corresponds to an energy content of 2 EJ [32]. Current common practice for dealing with the organic compounds in black liquor is mainly based on drying it and then recovering its energy content by burning it in a recovery boiler. However, it would be more profitable to convert the organic fraction of black liquor into useful and separable organic compounds. HTL is one of the most interesting solutions for such conversion, as it enables the wet biomass to be treated without drying [21].

\subsection{The Kraft Pulping Process}

Pulping processes are divided into different categories depending on the method used to separate the pulp from the wood, which range through mechanical, semi-chemical and chemi-mechanical to chemical pulping [31]. The Kraft pulping process uses sodium hydroxide and sodium sulfide in 
a purely chemical pulping process under alkaline conditions at high temperatures. Due to its fast delignification, the high quality of the pulp and the possibility of chemical recovery, Kraft pulping is the most popular chemical pulping process [31]. Figure 1 illustrates the principle of the Kraft pulping process [31].

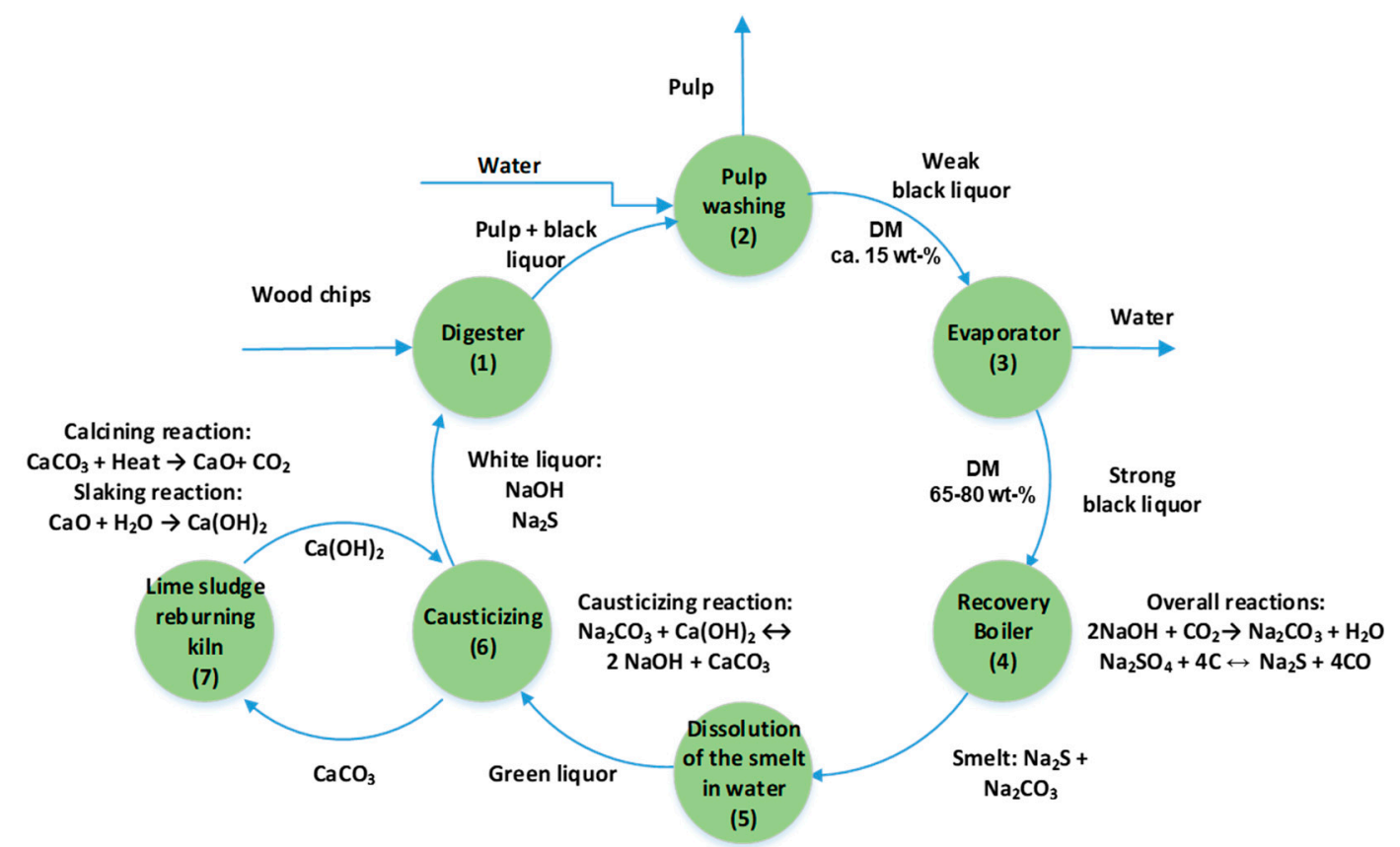

Figure 1. The main material flows in a Kraft pulp mill process. ( $D M=$ Dry Matter). The figure is redrawn from Biermann [33].

Beginning at the green circle (1) on the left of Figure 1, the wood chips are treated in the digester with white liquor, which contains mainly $\mathrm{NaOH}$ and $\mathrm{Na}_{2} \mathrm{~S}$. The pulping process occurs at a temperature between $433 \mathrm{~K}$ and $453 \mathrm{~K}$ under alkaline conditions for between $0.5-3 \mathrm{~h}$ [31]. The hydroxyl and hydrosulfide ions promote the breaking of the ether bonds between the lignin monomers, while the carbon-carbon bonds remain stable under these conditions [34]. During the pulping process, most of the lignin (ca. $90 \mathrm{wt} . \%$ ) from the wood fibers dissolves into the water-alkali solution. Also, a large amount of hemicellulose (between $30 \mathrm{wt} . \%$ and $70 \mathrm{wt} . \%$ ) and a small quantity of cellulose (ca. $10 \mathrm{wt} . \%$ ) dissolves into the black liquor [31,34-37]. Delignification in the digester mainly produces phenolic hydroxyl groups while the hemicellulose reacts mostly into hydroxyl carboxylates [34,37].

After digestion, the pulping product is washed (2) and the resulting pulp is separated and sent off for bleaching and drying processes. The remaining dissolved organic compounds and cooking chemicals form what is called weak black liquor [33]. As the water is evaporated from the black liquor (3), its solid content increases from $15 \%$ (weak black liquor) up to $80 \%$ (strong black liquor).

In the recovery boiler (4), any organic products in the black liquor are combusted [38]. The residue of the black liquor, mainly containing salts and some char, settles on the char bed, where both oxidation and reduction reactions occur at the top of the smelt bed. At this stage, the inorganic parts of the black liquor, i.e., the sulfates and sulfites formed during the previous steps, are reduced back to sulfides. The residual product at the bottom is called melt and mainly contains $\mathrm{Na}_{2} \mathrm{CO}_{3}$ and $\mathrm{Na}_{2} \mathrm{~S}$.

In the dissolving tank (5), the hot melt cools down and is dissolved into water, producing green liquor $[31,33,38]$. A proportion of the inorganic compounds, called green liquor dregs, is not water soluble and so it precipitates at the bottom of the dissolving tank and is removed from the process chemical loop [39]. The causticizing plant (6) restores the green liquor to white liquor through the removal of carbon dioxide and any remaining organics [31]. 
In the lime kiln (7), $\mathrm{CaCO}_{3}$ decomposes into quicklime, $\mathrm{CaO}$, and $\mathrm{CO}_{2}$. The quicklime $\mathrm{CaO}$ reacts with the water in a lime-slaking reaction producing calcium hydroxide [33]. Part of the quicklime will not react in the slaker, and will be removed from the chemical loop by slaker grits [33]. The white liquor is separated from the lime by filtration [33], and finally the regenerated and purified cooking chemicals are returned to the digester.

\subsection{Formation of Black Liquor}

The main compounds found in lignocellulosic biomass are cellulose, hemicellulose and lignin, although it also contains small quantities of ash and extracts such as pectin, aromatics, and proteins [40,41]. Its detailed composition depends on the type of biomass feedstock used. For instance, the proportions of cellulose, hemicellulose and lignin in softwood are $45-50 \mathrm{wt} . \%, 25-35 \mathrm{wt} . \%$ and 25-35 wt.\%, respectively [40], while the corresponding figures for straw are $33-40 \mathrm{wt} . \%, 20-25 \mathrm{wt} . \%$, and $15-20 \mathrm{wt} . \%$ [42].

The cell walls of plants consist of microfibrils that are built from lignin, hemicellulose and cellulose [41]. Straight-chain cellulose forms the basic structure of these microfibrils while cellulose holds the hemicellulose and lignin together via covalent bonds. Similarly, the lignin works as glue in the structure, making it resistant to chemical and mechanical treatments [41]. The chemical structures of cellulose, hemicellulose and lignin differ from each other significantly, which determines their respective resistance to chemical and mechanical treatment. Cellulose is an organic linear polymer (polysaccharide) that consists of hundreds to tens of thousands of D-glucose monomers linked by glycosidic bonds [43]. The main reason for cellulose's chemical recalcitrance is its high crystallinity, making it harder to treat than an amorphous starch. Hemicellulose is built from different polysaccharide units, such as xylan and glucomannan, but mostly consists of D-pentoses, so its structure is branched [43]. Lignin is a complex organic polyaromatic polymer, mainly built from three basic monomers, coniferyl alcohol, p-coumaryl alcohol and sinapyl alcohol [44]. The proportions of these building monomers vary depending on the source of the lignin. These monomers are linked to each other via numerous different bonds, such as alkyl-alkyl, aryl-aryl, alkyl-aryl and ether bonds [40]. The complex cross-linking of the monomers in the lignin forms a grid that is highly resistant to mechanical, chemical and biological treatment processes [40].

The degradation of lignin is a complex phenomenon in which chemical compounds degrade and form new compounds. The Kraft pulp mill process treats the lignin structures by breaking the chemical bonds, mainly $\beta-\mathrm{O}-4$ and $\alpha-\mathrm{O}-4$ ether bonds. The catalysts for this process are both hydroxyl and hydrosulfide ions [34,44]. Once the ether bonds have been split, there are a large number of hydroxyl groups in the resulting chemical compounds.

A recent study has shown just how many hundreds of different chemical compounds are derived from the original lignin in the Kraft pulp mill process [45]. Nevertheless, it must be emphasized that the process conditions and the origin of the wood chips have a great influence on the produced black liquor and its properties [45].

\subsection{The Composition of Black Liquor}

As stated above, the composition of black liquor depends on several factors, such as the process conditions in the digester, the composition of the white liquor, and ultimately, the origin of the wood feedstock. Therefore, the composition of black liquor varies according to local conditions, which can be significantly different from one plant to another. If black liquor is to be used as feedstock for the HTL process, the differences in the composition of the black liquor make it difficult to control the HTL process and its products. Table 1 shows two different compositions of softwood black liquor obtained with Kraft pulp mill processes from Sweden [46] and Finland [47]. 
Table 1. Compositions of softwood weak black liquor achieved from two Kraft pulp mills. Data retrieved from Arkell et al. [46] and Alekhina et al. [47].

\begin{tabular}{ccccccccc}
\hline Origin & Country & $\begin{array}{c}\text { Density } \\
\left(\mathbf{k g} / \mathbf{m}^{3}\right)\end{array}$ & $\begin{array}{c}\text { Total Dry } \\
\text { Solids } \\
(\mathbf{g} / \mathbf{L})\end{array}$ & $\begin{array}{c}\text { Hemicelluloses } \\
(\mathbf{g} / \mathbf{L})\end{array}$ & $\begin{array}{c}\text { Total } \\
\text { Lignin } \\
(\mathbf{g} / \mathbf{L})\end{array}$ & $\begin{array}{c}\text { Ash } \\
(\mathbf{g} / \mathbf{L})\end{array}$ & $\begin{array}{c}\text { Sodium } \\
(\mathbf{g} / \mathbf{L})\end{array}$ & Ref. \\
\hline $\begin{array}{c}\text { Softwood }\left(\mathrm{ND}^{\mathrm{c}}\right) \\
\text { Black liquor } \\
\begin{array}{c}\text { Softwood (Pine) } \\
\text { Black liquor }\end{array}\end{array}$ & Sweden & 1095 & 183 & 3.56 & 63.8 & 84.3 & 37.8 & {$[46]$} \\
\hline
\end{tabular}

${ }^{\mathbf{a}}$ Amount of total carbohydrates. ${ }^{\mathbf{b}}$ Not available. ${ }^{\mathbf{c}}$ Not Defined.

Typical organic compounds present in softwood Kraft lignin are guaiacyl compounds, while hardwood black liquor contains both syringyl and guaiacyl compounds [37]. Other chemical compounds are formic acid, acetic acid, methoxycatechols, benzene-1,2,3-triol derived compounds and aliphatic carboxylate acids $[37,48,49]$. Table 2 shows a typical elemental composition of dry pine black liquor.

Table 2. Elemental composition of dry pine black liquor (dry matter basis). Data is taken from Alén and Niemelä [37].

\begin{tabular}{ccccccccc}
\hline $\mathbf{C}$ & $\mathbf{H}$ & $\mathbf{O}$ & $\mathbf{N}$ & $\mathbf{S}$ & $\mathbf{N a}$ & $\mathbf{K}$ & $\mathbf{C l}$ & Others \\
\hline wt. $\%$ & wt. $\%$ & wt. $\%$ & wt. $\%$ & wt. $\%$ & wt. $\%$ & wt. $\%$ & wt. $\%$ & wt. $\%$ \\
\hline 38 & 3.6 & 33.1 & 0.1 & 4.8 & 19.1 & 0.9 & 0.2 & 0.2 \\
\hline
\end{tabular}

The inorganic fraction of pine black liquor consists of both unreacted cooking chemicals, i.e., $\mathrm{NaOH}$ and $\mathrm{Na}_{2} \mathrm{~S}$, and salts formed in the chemical pulping process, typically $\mathrm{Na}_{2} \mathrm{CO}_{3}, \mathrm{Na}_{2} \mathrm{SO}_{4}$ and $\mathrm{Na}_{2} \mathrm{SO}_{3}$, which are formed from sulfide oxidation and minerals contained in the wood [37] (see Table 3). When treating black liquor in the HTL process, these inorganic compounds can both catalyze reactions and cause blockages in pipes and heat exchangers. Therefore, it is important to understand how these compounds act under sub- and supercritical water conditions.

Table 3. Weight fractions of inorganic compounds in black liquor (dry matter basis). Other salts present in pine black liquor are mainly salts containing potassium and chlorine. Data is obtained from Niemelä and Alén [37].

\begin{tabular}{ccccccc}
\hline $\mathrm{Na}_{2} \mathbf{S}$ & $\mathrm{Na}_{2} \mathrm{SO}_{4}$ & $\mathrm{Na}_{2} \mathbf{S}_{2} \mathbf{O}_{3}$ & $\mathbf{N a}_{2} \mathbf{S O}_{3}$ & $\mathbf{N a O H}$ & $\mathbf{N a}_{2} \mathbf{C O}_{3}$ & Others \\
\hline wt. $\%$ & wt. $\%$ & wt. $\%$ & wt. $\%$ & wt. $\%$ & wt. $\%$ & wt. $\%$ \\
\hline 17 & 12 & 14 & 7 & 6 & 32 & 12 \\
\hline
\end{tabular}

\section{Hydrothermal Treatment}

Several routes for converting biomass into more useful energy carriers exist: thermochemical conversion, indirect liquefaction, physical extraction, biochemical conversion and direct combustion [50]. Thermochemical conversion divides into four main process technologies: Torrefaction, gasification, pyrolysis and hydrothermal treatment. Hydrothermal treatment (HTT) processes use either sub- or supercritical water as a reaction medium to convert the biomass into the desired product. The advantage of HTT processes is that they can use wet biomass, thereby saving the energy required for biomass drying. Hydrothermal treatment processes can be divided into three subcategories, hydrothermal carbonization (HTC), hydrothermal liquefaction (HTL) and hydrothermal gasification (HTG).

The severity of the process conditions varies in different thermochemical conversions. Hydrothermal carbonization takes place at temperatures between $473 \mathrm{~K}$ and $623 \mathrm{~K}$ and at pressures ranging from $2 \mathrm{MPa}$ to $10 \mathrm{MPa}$ [51-54]. The hydrothermal carbonization process produces biochar 
with chemical properties similar to fossil lignite [51-53]. Hydrothermal gasification takes place at the highest temperature range of HTT processes varying between $623 \mathrm{~K}$ and $973 \mathrm{~K}$ and at a pressure above the critical pressure of water (221 bar) [52]. Treating biomass in the HTG process mainly produces gases, such as $\mathrm{H}_{2}, \mathrm{CO}_{2}, \mathrm{CH}_{4}$ and other hydrocarbon gases [52,55]. Hydrothermal gasification can be divided into low- and high-temperature HTG. The low-temperature HTG takes place at temperatures below $723 \mathrm{~K}$, where the main product is a methane-rich gas and it typically involves the use of a catalyst [56,57]. The high-temperature HTG typically operates at temperatures above $723 \mathrm{~K}$, preferably leading to the production of hydrogen [55], and is often non-catalytic. Hydrothermal liquefaction is typically performed in reaction conditions that lie somewhere between those of HTC and HTG. The reaction temperature of HTL varies from $523 \mathrm{~K}$ up to $723 \mathrm{~K}$ as the pressure range varies between $10 \mathrm{MPa}$ and $35 \mathrm{MPa}$ [22,52]. Hydrothermal liquefaction produces bio-oil, similar to fossil heavy crude, as the main product, but the process also produces char, water soluble organics (WSO) and gaseous products. The mass yield of carbon from black liquor to bio-oil can be up to $80 \mathrm{wt} . \%$ [58].

\subsection{The Properties of Water under Sub- and Supercritical Conditions}

Water's properties change significantly with changing pressure and temperature under suband supercritical water conditions. When the reaction condition is above the critical point of water $\left(\mathrm{T}_{\mathrm{C}}=647.17 \mathrm{~K}\right.$ and $\mathrm{P}_{\mathrm{C}}=22.064 \mathrm{MPa}$ [59]), the water is in neither its liquid nor its gaseous phase. Figures 2-4 show some of the most important properties of water for HTL process at various temperatures and pressures under sub- and supercritical water conditions.

The density of water decreases as the temperature rises under sub- and supercritical water conditions (see Figure 2). Under supercritical conditions, water's density can be either gas-like or liquid-like, depending on the reaction conditions. For example, at $650 \mathrm{~K}$ water density is $218 \mathrm{~kg} / \mathrm{m} 3$ at $22.5 \mathrm{MPa}, 489 \mathrm{~kg} / \mathrm{m}^{3}$ at $25 \mathrm{MPa}, 637 \mathrm{~kg} / \mathrm{m}^{3}$ at $50 \mathrm{MPa}$ and $815 \mathrm{~kg} / \mathrm{m}^{3}$ at $200 \mathrm{MPa}$ [60]. Water enthalpy increases with rising temperature, but the growth of the enthalpy is more notable at a phase transition or (pseudo)critical point (see Figure 2).

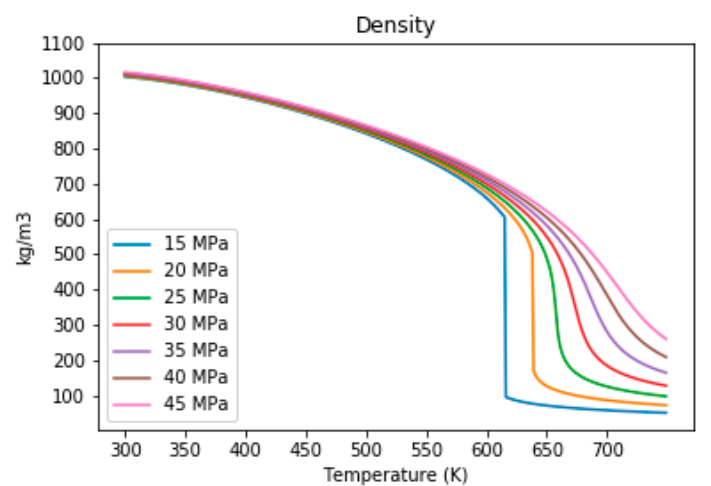

(a)

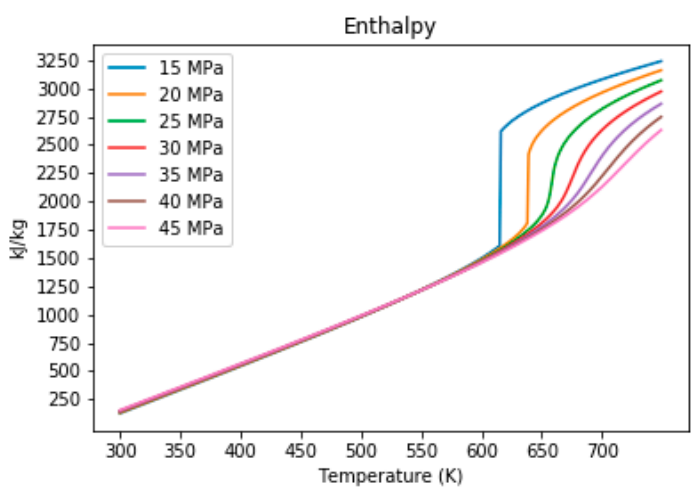

(b)

Figure 2. Density and enthalpy of water as a function of temperature at various pressures. The data points are taken from Wagner and Pruß [60]: (a) density; (b) enthalpy.

As the temperature and pressure exceed the critical point of water, the values of both the heat capacity at constant pressure $\left(C_{p}\right)$ and the heat capacity at constant volume $\left(C_{v}\right)$ have peaks (see Figure 3). However, increasing pressure leads to a lower maximum peak value for the specific heat capacity of water. 


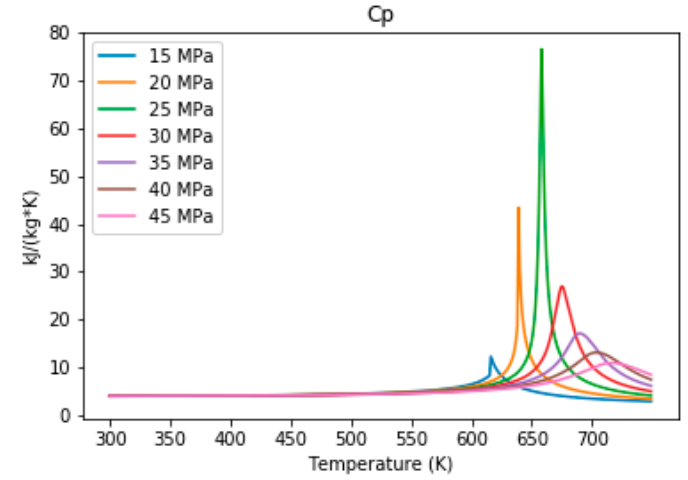

(a)

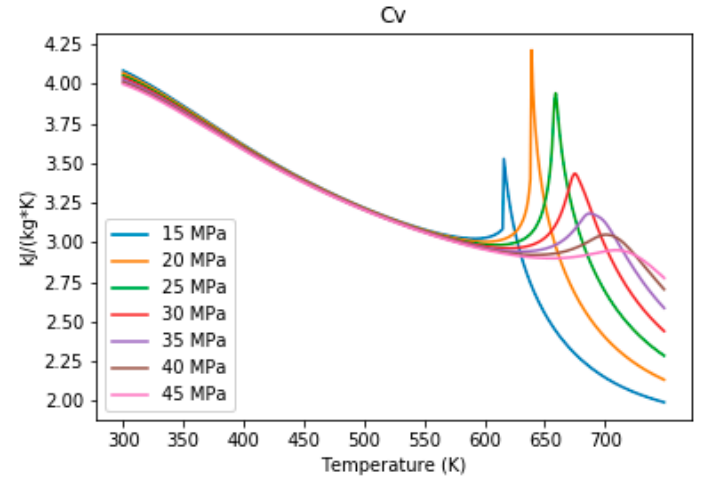

(b)

Figure 3. Values of specific heat capacities of water as a function of temperature at various pressures. The data points are taken from Wagner and Pruß [60]: (a) $C_{p} ;(\mathbf{b}) C_{v}$.

The ionic constant of water (e.g., ionic product) determines the equilibrium of water dissociation into $\mathrm{H}_{3} \mathrm{O}^{+}$and $\mathrm{OH}^{-}$ions, which is around $10-14(p K w=14)$ in ambient conditions and increases to around $10-11.1$ at $573 \mathrm{~K}$ at $25 \mathrm{MPa}$ (see Figure 4). However, any further increase of the temperature above the critical point decreases the ionic constant value of the water; for example, its value is $10-16.6$ at $673 \mathrm{~K}$ and $25 \mathrm{MPa}$. The high concentration of $\mathrm{H}_{3} \mathrm{O}^{+}$and $\mathrm{OH}^{-}$under subcritical water conditions is associated with a greater rate of ionic reactions, i.e., hydrolysis, while the low ionic constant under supercritical conditions can partially explain why radical reactions are favored under these conditions [61,62].

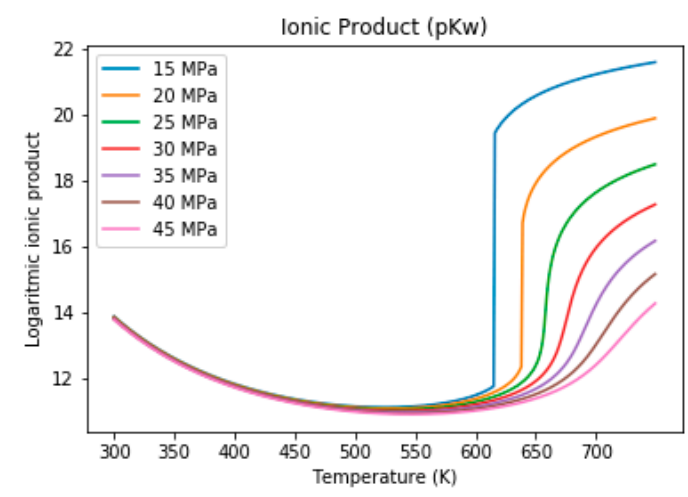

(a)

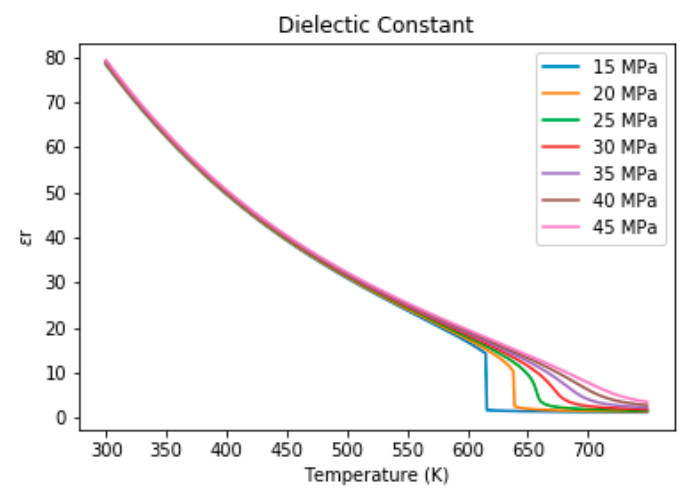

(b)

Figure 4. Logarithmic ionic product $\left(p K_{w}\right)$ and dielectric constant $\left(\varepsilon_{0}\right)$ of water as a function of temperature at various pressures. The data points are taken from IAPWS [63,64]: (a) Ionic product $\left(\mathrm{pK}_{\mathrm{W}}\right) ;(\mathbf{b})$ Dielectric Constant.

The dielectric constant of water at ambient conditions is around 80, in line with its high polarity and solubility properties, but it decreases to near 1 at $648 \mathrm{~K}$ and $22.5 \mathrm{MPa}$ (see Figures 4 and 5), when it is lower than benzene or pentane. This makes supercritical water a highly polarized solvent able to dissolve non-polar hydrocarbons. The lower dielectric constant of water is explained by the significant increase in electron mobility as the temperature rises near the critical temperature [65]. In addition to the lower solvent polarity, the dielectric constant influences the solubility of salts, which decreases with increasing temperatures and pressures [66]. The salts' low solubility can cause problems in the process if it precipitates on the hot surfaces of the heat exchangers, preventing heat transfer and causing possible blockages [67]. The phase behavior of salts in hot and pressurized water is complex and is described in more detail in the next section.

To summarize, the unique properties of sub- and supercritical water make it an excellent medium for converting wet organic biomass into higher-value bio-oil. Sub- and supercritical water's ability 
to dissolve non-polar organic compounds and to favor either ionic or radical reactions by adjusting temperature and pressure makes it a great candidate for the efficient treatment of black liquor organic matter. However, the low solubility of salts under supercritical water conditions can cause clogging in the HTL process (see Section 3.2).

\subsection{Salt Separation}

As discussed above in Section 2.3, black liquor contains large quantities of salts. Thus, understanding the behavior of salts under HTL conditions is important in the HTL black liquor process as the liquor can be treated to prevent fouling and/or techniques can be used to remove the salts efficiently. The phase behaviors of salts in water have been classified by Valyashko $[68,69]$, who has derived 26 full phase diagrams for binary salt-water systems. Following this classification, salts can be classified into two main categories: Type 1 and Type 2 salts. The categories of the main salts present in black liquor are given in Table 4.

Table 4. Classification of salts commonly found in black liquor. Based on Rumyantsev [70] and Wang et al. [71]. Note that this classification stands for pure salt in supercritical water, and that a mixture of salts may behave completely differently than the individual salts. Salts with unknown phase behaviors are marked with a dash (-).

\begin{tabular}{ccccccccc}
\hline Ions & $\mathbf{H O}^{-}$ & $\mathrm{Cl}^{-}$ & $\mathrm{CO}_{3}{ }^{2-}$ & $\mathbf{S O}_{4}{ }^{2-}$ & $\mathbf{S}_{2} \mathrm{O}_{3}{ }^{2-}$ & $\mathbf{S O}_{3}{ }^{2-}$ & $\mathbf{H S}^{-}$ & $\mathbf{S}^{2-}$ \\
\hline $\mathrm{Mg}^{2+}$ & 2 & 1 & 2 & 2 & & - & - & - \\
$\mathrm{Ca}^{2+}$ & 2 & 1 & 2 & 2 & Not & - & - & - \\
$\mathrm{Na}^{+}$ & 1 & 1 & 2 & 2 & stable & \\
$\mathrm{K}^{+}$ & 1 & 1 & 1 & 2 & & - & 1 & 1 \\
\hline
\end{tabular}

${ }^{a}$ Readily decomposes into a mixture of sulfite, sulfate, and sulfide ions.

Type 1 salts are characterized by a solubility which increases with increasing temperature, i.e., the temperature coefficient of solubility (t.c.s.) is positive. This translates into the formation of a dense, salt-rich liquid-like phase and a salt-depleted vapor-like phase (see Figure 5, left) [68]. Type 2 salts are characterized by a change in the sign of the t.c.s., meaning that at a certain temperature, the solubility of the salt starts to decrease causing the salt to precipitate, in equilibrium with a salt-depleted fluid (see Figure 5, right).

As shown in Table 4, two of the main salts present in black liquor are Type 2, i.e., sodium carbonate and sulfate, while the sodium sulfide and the hydroxide are Type 1. Unfortunately, no data is available on the phase behavior of sodium sulfite, but thiosulfate is known to readily decompose above $250^{\circ} \mathrm{C}$ [72]. Please note that salt-water phase behavior in SCW follows the trend that the larger the cation or the anion, the more likely the salt is to behave as Type 1. For instance, for a given anion, the chances of a salt being Type 1 (liquid brine formed) follows this order: $\mathrm{K}^{+}>\mathrm{Na}^{+}>\mathrm{Li}^{+}$, while for a given cation, the order is: $\mathrm{Br}^{-}>\mathrm{Cl}^{-}>\mathrm{F}^{-}$.

It is almost impossible to predict the behavior of salt mixtures in supercritical water as the salts in a mixture may behave differently than they do when they are single salts. Their behavior may be influenced by the salt composition, the presence of organics, or pressure and temperature $[69,73,74]$. For instance, while $\mathrm{Na}_{2} \mathrm{CO}_{3}$ and $\mathrm{K}_{2} \mathrm{SO}_{4}$ are Type 2 salts, when mixed they behave as a Type 1 salt [73], probably as a result of the formation of the Type 1 salt, $\mathrm{K}_{2} \mathrm{CO}_{3}$. Similarly, the Type 2 salts, $\mathrm{Na}_{3} \mathrm{PO}_{4}$ and $\mathrm{K}_{2} \mathrm{SO}_{4}$, have an overall Type 1 salt solution behavior below ca. $400{ }^{\circ} \mathrm{C}$. This can be attributed to the permutation of the ions [75] to form Type $1 \mathrm{~K}_{3} \mathrm{PO}_{4}$ and Type $2 \mathrm{Na}_{2} \mathrm{SO}_{4}$ [74]. With a salt mixture that leads to competitive salt precipitates (Type 2) and liquid brine formation (Type 1), the brine may dissolve (or disperse) the precipitated solids. This may explain the apparent Type 1 behavior of the mixture of the two salts and the absence of any accumulation of salts in a vessel (fouling). This concept can be exploited to prevent or limit Type 2 salt deposition [76]. 
The effect of the presence of organic compounds on the phase behavior of salts in water has been studied with two model organic compounds. The presence of $20 \mathrm{wt}$.\% glycerol in a Type $1 \mathrm{~K}_{3} \mathrm{PO}_{4}$ aqueous solution results in an increase in the temperature required to observe the formation of a salt-rich liquid phase [77]. This has been attributed to the higher fluid density of the glycerol-water mixture compared to that of pure water under the same conditions. The same conclusion could be drawn with the addition of $10 \mathrm{wt}$.\% 2-propanol to a $\mathrm{Na}_{2} \mathrm{SO}_{4}: \mathrm{K}_{2} \mathrm{SO}_{4}$ (2:1 molar ratio) aqueous solution. While simple alcohols generally seem to decrease the saturation temperature, more studies are required to better understand the impact of organics on salt phase behavior. Please note that these conclusions do not hold for conditions favoring the significant production of gas (gasification of biomass) as the gas produced will decrease the density of the mixture and hence favor salt precipitation.

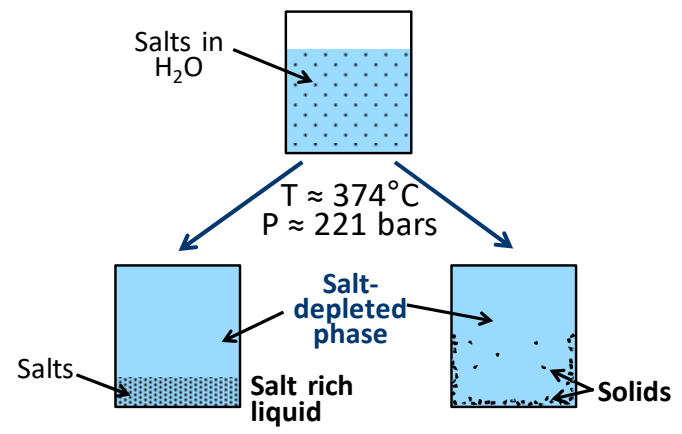

Type 1 salts

Type 2 salts

Figure 5. Schematic representation of the behavior of Type 1 and 2 salts at high pressure and temperature.

Therefore, it is hard to predict the phase behavior of black liquor salts and no specific study has yet been published on these salt mixtures. However, De Blasio et al. [78] have recently reported the blocking up of a continuous flow reactor during the gasification of black liquor. This plugging occurred at a temperature of $600{ }^{\circ} \mathrm{C}$ as it rose from $500{ }^{\circ} \mathrm{C}$. However, it is not clear from this study whether the precipitation occurred only at this temperature or started at a lower temperature without reaching a critical quantity of salt deposits. In a recent study with a model salt solution of $\mathrm{NaOH}, \mathrm{Na}_{2} \mathrm{SO}_{4}$, $\mathrm{Na}_{2} \mathrm{CO}_{3}$ and $\mathrm{Na}_{2} \mathrm{~S}$ in concentrations representative of black liquor (molar ratio 1:4.1:1.2:2.0, $3.71 \mathrm{wt} . \%$ total salts in water), it was concluded that this salt mixture behaves as Type 2, i.e., solid salt deposition, at $400-415^{\circ} \mathrm{C}$ and 290 bars [71]. The same conclusion was drawn with weak black liquor from a pine tree. Figure 6 shows the solubility of various salts typically present in black liquor under conditions relevant for hydrothermal treatment. The concentrations are given as a function of pure water density to better reflect the variation of pressure and temperature at the available data [79]. The solubility of the Type 1 salts is overall higher than that of the Type 2 salts at comparable water densities. Please note that the solubility of $\mathrm{Na}_{2} \mathrm{CO}_{3}$ and $\mathrm{Na}_{2} \mathrm{SO}_{4}$ in a mixture is very close to that of pure single salts at water densities of $150-450 \mathrm{~kg} / \mathrm{m}^{3}$, but sulfate solubility decreases above $450 \mathrm{~kg} / \mathrm{m}^{3}$ as a result of a "common-ion effect" [80]. At temperatures and pressures typically used for HTL, corresponding to water densities ranging roughly from $400 \mathrm{~kg} / \mathrm{m}^{3}$ to $750 \mathrm{~kg} / \mathrm{m}^{3}$, the concentration of sodium sulfate can go down from ca. $200 \mathrm{~g} / \mathrm{kg}$ to $2 \mathrm{~g} / \mathrm{kg}$, and for sodium carbonate it goes down to $5 \mathrm{~g} / \mathrm{kg}$. This is 50 times and 100 times lower than their solubility at standard conditions, respectively. This indicates that under certain conditions these salts can effectively precipitate, which of course can result in any pipes and vessels getting fouled up. An extrapolation of the data for potassium hydroxide indicates minimal concentrations at the lowest limit of HTL water densities of 5-20 g/kg, 30-110 times lower than standard solubility. 


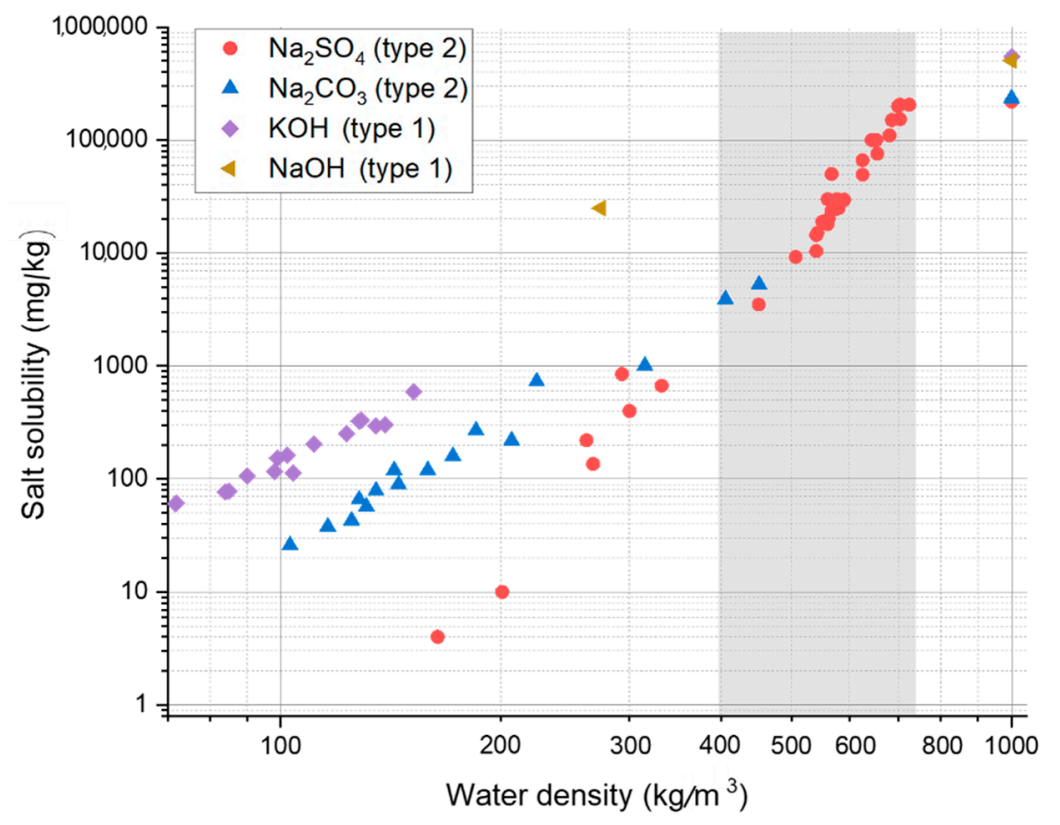

Figure 6. Solubility in the salt-depleted phase of various inorganic salts typically present in black liquor as a function of water density (based on [80]). The type of salt is indicated in parentheses. The grey shaded zone indicates the water density range typically encountered in $\mathrm{HTL}$, e.g., $23 \mathrm{MPa} / 390{ }^{\circ} \mathrm{C}$ and $15 \mathrm{MPa} / 300{ }^{\circ} \mathrm{C}$ leading to water densities of $470 \mathrm{~kg} / \mathrm{m}^{3}$ and $725 \mathrm{~kg} / \mathrm{m}^{3}$ respectively.

It is well documented that the low solubility of salts in (near) supercritical water leads to pipes getting fouled up and blocked $[67,78,81-86]$. It has also been shown that fouling can be reduced by the addition of carbon particles into the fluid stream $[83,87,88]$. This is probably because the particles act as nucleation sites for the precipitation of salts. Several research groups have taken advantage of the low salt solubility to extract salts from a main stream, using, for instance, continuous filtration [89], semi-continuous salt trap [75,82,84], or continuous extraction [77,90-92]. At the Paul Scherrer Institute, a salt separator has been designed to continuously separate and extract the dense salt-rich liquid formed under supercritical conditions $[77,90,91]$. This salt separator consists of a vertical pressure vessel heated up through a temperature gradient and equipped with a tube at its bottom via which the preheated feed is injected. The feed rapidly heats up to supercritical conditions in the vessel resulting in the separation of the Type 1 salts present into a dense liquid phase (brine) that accumulates at the bottom of the vessel. An outlet allows this brine to be continuously extracted using a liquid mass flow controller, while the salt-depleted phase containing most of the feed organics (main stream) exits at the top of the vessel. At its best, more than $95 \%$ of a $\mathrm{K}_{2} \mathrm{SO}_{4}$ and $\mathrm{Na}_{2} \mathrm{CO}_{3}$ mixture entering the salt separator could be recovered as concentrated brine [90]. It should be noted; however, that some Type 2 salts, such as magnesium and calcium hydroxide or carbonates, tend to stick to the hot walls of the salt separator, and can accumulate in the vessel.

\subsection{Hydrothermal Liquefaction (HTL)}

As a process, HTL mimics the natural mechanism by which biomass transforms into crude oil deep underground over a period of millions of years. The hydrothermal liquefaction process produces a liquid product called bio-oil or biocrude. The bio-oils produced with HTL are very different from those produced with pyrolysis processes. For example, HTL bio-oil has a higher heating value due to its lower oxygen content and it is, therefore, more resistant to aging $[9,93]$. Nevertheless, any bio-oil consists of numerous different chemical compounds whose amounts and concentrations depend greatly on the input materials and the reaction conditions.

Water plays several different roles in the HTL process because it works simultaneously as a reactant, solvent, reaction medium and catalyst [94]. The properties of water under sub- and supercritical 
conditions enhance both the dissolution and degradation of lignin. Lignin degradation occurs via different reactions, such as hydrolysis, alkylation and repolymerization reactions $[95,96]$. The separation of the liquid product occurs in a phase separator, where the non-polar bio-oil fraction separates from the aqueous fraction containing polar organic compounds, i.e., water soluble organics [61]. The WSO fraction contains mainly small organic compounds, such as organic acids or small alcohols. The non-polar bio-oil fraction contains a large variety of different organic compounds, such as phenolic compounds, aliphatic compounds and oligomers [61]. The typical properties of a bio-oil are, for example, that it has a lower oxygen content and a higher heating value than the original feedstock [61].

The reaction mechanisms of HTL include competing parallel and sequential reactions, such as hydrolysis and recondensation. These result in a very large variety of chemical products that are extremely challenging to analyze properly. In fact, at the time of writing no complete reaction mechanism of lignin degradation under near and supercritical water conditions has yet been identified [95]. Therefore, most of the proposed reaction mechanisms are significantly more simplified than any real reaction mechanism [97-100]. The reaction mechanisms and the effect of different factors, such as co-solvents and catalysts, must be understood in order to produce high quality bio-oil with a high yield. This is particularly important with regard to the reduction of both char and gaseous co-products, which can significantly reduce bio-oil yields [101]. Under subcritical conditions, alkali catalysts, such as $\mathrm{KOH}$ and $\mathrm{K}_{2} \mathrm{CO}_{3}$, are used to decrease char formation [102]. Alkali salts catalyze the water-gas shift (WGS) reaction, where carbon monoxide and water react to produce hydrogen and carbon dioxide [102-104]. The hydrogen produced in WGS may act as a reducing agent in HTL reactions, thus improving the overall quality of the bio-oil produced [102].

The reaction parameters that have an influence on the HTL of black liquor are temperature, pressure, residence time, solvents, catalysts and feedstock. Table 5 gathers the results from the main reported HTL experiments performed using either black liquor or black liquor-derived lignin as feedstock. In several studies, LignoBoost lignin was used. LignoBoost lignin is separated from black liquor in a multi-phase process that includes unit processes, such as acidification, filtration and washing [105]. In addition to the LignoBoost process, a common way to separate lignin from black liquor is to use membrane filtration, precipitation and dewatering as extraction method [11].

Table 5. Feedstocks and process types used in the studies reported in this review. Both elemental composition and the $H H V$ of the feedstocks are given on a dry matter basis.

\begin{tabular}{|c|c|c|c|c|c|c|c|c|c|c|c|c|}
\hline Feed & Reactor Type & $\begin{array}{c}\text { Size/ } \\
\text { Capa-City }\end{array}$ & $\begin{array}{c}\text { Moi-Sture } \\
\text { wt. } \%\end{array}$ & $\begin{array}{c}\mathrm{C} \\
\text { wt. } \%\end{array}$ & $\begin{array}{c}\mathrm{H} \\
\text { wt. } \%\end{array}$ & $\begin{array}{c}\mathrm{O}^{\mathrm{a}} \\
\text { wt. } \%\end{array}$ & $\begin{array}{c}\text { S } \\
\text { wt. } \%\end{array}$ & $\begin{array}{c}\mathrm{N} \\
\text { wt. } \%\end{array}$ & $\begin{array}{c}\mathrm{Na} \\
\text { wt. } \%\end{array}$ & $\begin{array}{c}\text { Ash } \\
\text { wt. } \%\end{array}$ & $\begin{array}{c}H H V \\
(\mathrm{MJ} / \mathrm{kg})\end{array}$ & Ref \\
\hline Kraft lignin & Batch & $30 \mathrm{~mL}$ & - & - & - & - & - & - & - & - & - & [106] \\
\hline $\begin{array}{l}\text { Ligno-Boost } \\
\text { lignin }\end{array}$ & $\begin{array}{l}\text { Continuous, } \\
\text { catalytic Fixed } \\
\text { Bed Reactor }\end{array}$ & $1 \mathrm{~kg} / \mathrm{hr}$ & 3.6 & 65.6 & 5.7 & 26 & 1.85 & - & - & 0.8 & 27.7 & [107] \\
\hline Black liquor & Batch & $10 \mathrm{~mL}$ & - & 61.8 & 6.1 & 23.0 & 2.29 & 0.31 & 0.2 & - & - & [58] \\
\hline Black liquor & Batch & $200 \mathrm{~mL}$ & - & 30.5 & 3.2 & $66.7^{\mathrm{b}}$ & 0 & - & 6.5 & 2.5 & - & [108] \\
\hline $\begin{array}{l}\text { Alkaline } \\
\text { lignin }\end{array}$ & Batch & $14 \mathrm{~mL}$ & - & 49 & 4.4 & \multicolumn{2}{|c|}{$46.6^{b}$} & 0 & - & - & - & [109] \\
\hline $\begin{array}{l}\text { Ligno-Boost } \\
\text { lignin }\end{array}$ & $\begin{array}{l}\text { Contnuous, } \\
\text { catalytic Fixed } \\
\text { Bed Reactor }\end{array}$ & $1 \mathrm{~kg} / \mathrm{hr}$ & 32.6 & 65.6 & 5.7 & 26 & - & - & - & 0.8 & 27.7 & [110] \\
\hline $\begin{array}{l}\text { Alkaline } \\
\text { lignin }\end{array}$ & Batch & $5 \mathrm{~mL}$ & - & - & - & - & - & - & - & - & - & [95] \\
\hline Indulin AT & $\operatorname{CSTR}^{\mathrm{c}}$ & $99 \mathrm{~mL}$ & 3.6 & 64.4 & 6.7 & 27.1 & 1.8 & - & - & 1.9 & 26.8 & [111] \\
\hline $\begin{array}{l}\text { Ligno-Boost } \\
\text { lignin }\end{array}$ & $\begin{array}{l}\text { Contnuous, } \\
\text { catalytic Fixed } \\
\text { Bed Reactor }\end{array}$ & $2 \mathrm{~kg} / \mathrm{hr}$ & 32.6 & 65.6 & 5.7 & 26 & 1.8 & - & 0.2 & 0.8 & 27.7 & $\begin{array}{l}{[112,} \\
113]\end{array}$ \\
\hline $\begin{array}{l}\text { Ligno-Boost } \\
\text { lignin }\end{array}$ & $\begin{array}{l}\text { Contnuous, } \\
\text { catalytic Fixed } \\
\text { Bed Reactor }\end{array}$ & $1 \mathrm{~kg} / \mathrm{hr}$ & 32.6 & 65.6 & 5.7 & 26 & 1.8 & - & 0.2 & 0.8 & 27.7 & $\begin{array}{l}{[114,} \\
115]\end{array}$ \\
\hline $\begin{array}{c}\text { Kraft Black } \\
\text { liqour }\end{array}$ & Batch & $1000 \mathrm{~mL}$ & 66 & 33.7 & 3.9 & 38.4 & 4.3 & 0.1 & 18.0 & 50.1 & 14.1 & [116] \\
\hline
\end{tabular}




\subsection{The Effects of the Process Parameters}

The efficient production of high-quality bio-oil in an HTL process requires knowledge of the effects of different process parameters on the bio-oil's quantity and quality. The most important parameters are the reaction temperature, the residence time and the initial concentration of lignin. The effect of each parameter is different. For example, the reaction temperature affects the reaction rates, while altering the residence time affects the yield of certain components.

\subsubsection{Temperature and Pressure}

The temperature and pressure of HTL are key process parameters because they affect reaction condition, such as density and the amounts of ionic compounds. In addition, the reaction temperature also influences certain reaction mechanisms and the kinetics of various competing reactions; subcritical water properties prefer ionic reactions, whereas gas-like density in a supercritical water condition favors radical reactions $[22,107,117]$. However, it is possible to enhance ionic reactions under supercritical conditions by increasing the fluid density [118]. Table 6 below summarizes the main information gleaned from key research articles on experiments with either black liquor or black liquor-derived products. There are differences in the ways in which mass yields are expressed in different studies, so they are not directly comparable. Figure 7 shows bio-oil yields as a function of temperature achieved in various studies. The energy yield is defined by Equation (1).

$$
\text { Energy Yield }=\frac{\text { Mass Yield } \cdot H H V_{\text {product }}}{H H V_{\text {feed }}}
$$

Table 6. The maximum bio-oil yields and the corresponding process conditions.

\begin{tabular}{|c|c|c|c|c|c|c|}
\hline Feed & $\begin{array}{l}\text { Reactor } \\
\text { Type }\end{array}$ & $\begin{array}{c}\text { Max Mass } \\
\text { Yield }^{\text {a }}\end{array}$ & $\begin{array}{l}\text { Energy } \\
\text { Yield d }\end{array}$ & $\begin{array}{c}\text { Process } \\
\text { Conditions }\end{array}$ & $\begin{array}{l}\text { Resi-Dence } \\
\text { Time }\end{array}$ & Ref. \\
\hline Kraft lignin & Batch & $62 \mathrm{wt.} \%$ & - & Temperature $623 \mathrm{~K}$ & $5 \mathrm{~min}$ & [106] \\
\hline $\begin{array}{l}\text { LignoBoost } \\
\text { lignin }\end{array}$ & $\begin{array}{l}\text { Continuous, } \\
\text { catalytic } \\
\text { Fixed Bed } \\
\text { Reactor }\end{array}$ & 87.7 wt. $\%$ & $98.5 \%$ & $\begin{array}{c}\text { Temperature } 583 \mathrm{~K} \text {, Pressure } \\
25 \mathrm{MPa} \text {, Phenol } 4.0 \text { wt. } \% \\
\mathrm{~K}_{2} \mathrm{CO}_{3} 1.6 \text { wt. } \% \text {, Solid } \\
\text { catalyst: } \mathrm{ZrO}_{2}\end{array}$ & $10-13 \mathrm{~min}$ & {$[107,119]$} \\
\hline Black liquor & Batch & 78 wt. $\%$ & - & $\begin{array}{l}\text { Temperatures of } 643 \mathrm{~K} \text { and } \\
653 \mathrm{~K} \text { corresponding } \\
\text { pressures of } \sim 340 \text { bar and } \\
\sim 410 \text { bar, initial lignin } 5 \text { wt. } \%\end{array}$ & $1 \mathrm{~h}$ & [58] \\
\hline $\begin{array}{l}\text { Alkali lignin } \\
\text { (Sigma-Aldrich) }\end{array}$ & Batch & 90 wt. $\%$ b & - & $\begin{array}{c}\text { Temperature } 593 \mathrm{~K} \text {, ethanol } \\
50 \% \text { (vol-\%), Initial } \mathrm{H}_{2} \\
\text { pressure } 5 \mathrm{MPa}\end{array}$ & $2 \mathrm{~h}$ & [109] \\
\hline $\begin{array}{l}\text { Kraft Black } \\
\text { Liquor (soft } \\
\text { wood) }\end{array}$ & Batch & $70 \mathrm{wt} . \%^{\mathrm{c}}$ & $52.2 \% \mathrm{~d}$ & $\begin{array}{c}\text { Temperature } 623 \mathrm{~K}, \mathrm{Na}_{2} \mathrm{CO}_{3} \\
\text { addition } 13.2 \mathrm{wt} . \% \text { of black } \\
\text { liquor dry matter }\end{array}$ & $45 \mathrm{~min}$ & [116] \\
\hline
\end{tabular}

Orebom et al. [58] studied the HTL of fresh, weak (low solid concentration) black liquor at a temperature of 613-693 K and a residence time of one hour in a batch reactor. Over that temperature range, the bio-oil yield increased from ca. $67 \mathrm{wt} . \%$ to a maximum of $78 \mathrm{wt} . \%$ (ca. $648 \mathrm{~K}$ ), before falling back to ca. $60 \mathrm{wt} . \%$ at $693 \mathrm{~K}$. 

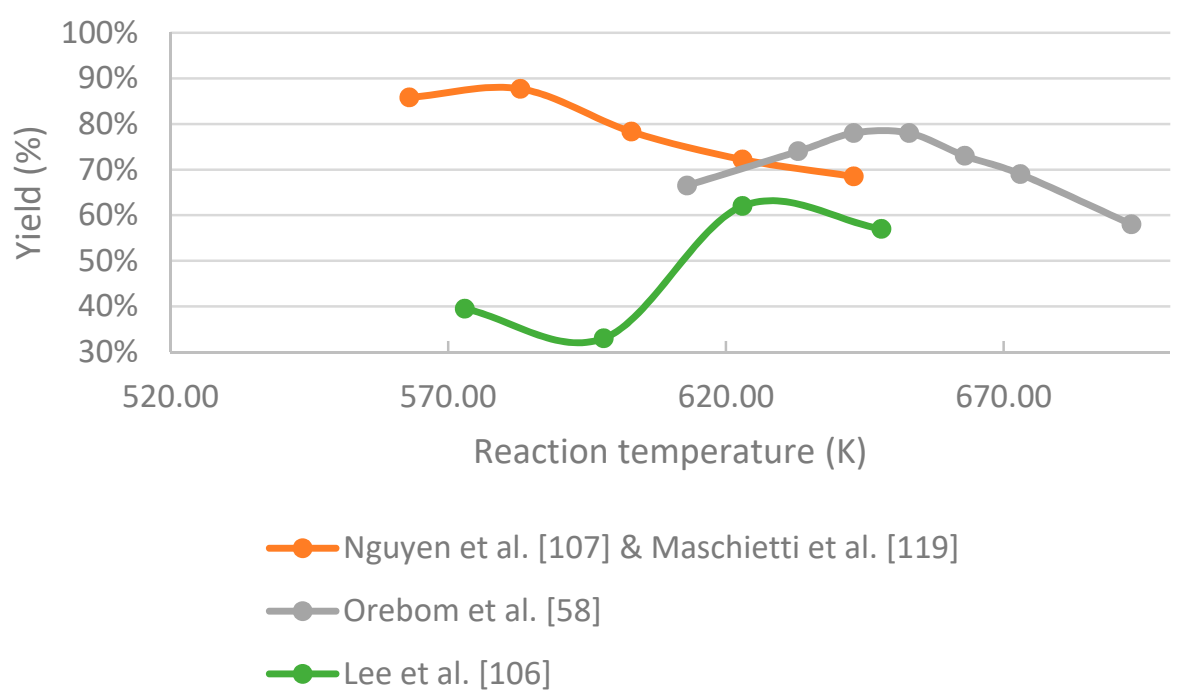

Figure 7. Mass yield of bio-oil as a function of operating temperature. The curves are guides to the eye.

Lee et al. [106] studied the degradation of Kraft lignin under hydrothermal conditions in a batch reactor at temperatures from $573 \mathrm{~K}$ to $648 \mathrm{~K}$ with and without ethanol. The experiments without ethanol led to the highest bio-oil yield of ca. $62 \mathrm{wt} . \%$ at $623 \mathrm{~K}$ (residence time $5 \mathrm{~min}$ ). The general trend in experiments without ethanol is that at the same residence time $(5 \mathrm{~min})$, a higher reaction temperature leads to higher bio-oil yields, at least for a temperature range of from $573 \mathrm{~K}$ to $648 \mathrm{~K}$. At the same time, the lowest solid residue (SR) yield was achieved at the highest reaction temperatures, that is ca. $30 \mathrm{wt} . \%$ at $623-648 \mathrm{~K}$. The use of lower reaction temperatures or longer residence times increased the SR yield. For example, the SR yield was about $56 \mathrm{wt} . \%$ at $573 \mathrm{~K}$ and at $20 \mathrm{~min}$. Lee et al. [106] also reported the number-average molecular weight $\left(M_{n}\right)$ and the weight-average molecular weight $\left(M_{w}\right)$ of bio-oils at temperatures of $573 \mathrm{~K}$ and $623 \mathrm{~K}$ and after a residence time of $30 \mathrm{~min}$. As the reaction temperature increased from $573 \mathrm{~K}$ to $623 \mathrm{~K}$, the $M_{n}$ and $M_{w}$ of biocrude increased from ca. $330 \mathrm{~g} / \mathrm{mol}$ to $400 \mathrm{~g} / \mathrm{mol}$ and $660 \mathrm{~g} / \mathrm{mol}$ to $880 \mathrm{~g} / \mathrm{mol}$, respectively. They assumed that the increase in $M_{w}$ and $M_{n}$ was due to the repolymerization of the instable phenolic intermediates, which has a greater effect at higher temperatures. In addition, they proposed that the decrease in the amount of SR and the increase in both $M_{n}$ and $M_{w}$ with rising temperature indicates that a higher temperature decreases carbonization, thereby favoring the formation of heavier organics.

Nguyen et al. [107] studied the effect of changing the reaction temperature between $563 \mathrm{~K}$ and $643 \mathrm{~K}$ for the HTL of LignoBoost at $25 \mathrm{MPa}$ and at residence time of ca. 10-13 min in a continuous pilot plant. The authors reported a global decrease in bio-oil and energy yields from $85 \mathrm{wt} . \%$ to $69 \mathrm{wt} . \%$ as the temperature increased from $563 \mathrm{~K}$ to $643 \mathrm{~K}$. Similarly, the increase of temperature resulted in an increasing yield of WSO from $5 \mathrm{wt} . \%$ to $11 \mathrm{wt} . \%$ although there was also a slight increase in the char yield from $18 \mathrm{wt} . \%$ to $21 \mathrm{wt} . \%$. The difference is due to the impact of the temperature in the conditions used. Indeed, in this test, $4.0 \mathrm{wt} . \%$ of phenol were added to this purified lignin residue LignoBoost, along with $1.6 \mathrm{wt} . \% \mathrm{~K}_{2} \mathrm{CO}_{3}$ and $\mathrm{ZrO}_{2}$ as solid catalyst.

The reaction temperature affects not only the yield but also the nature of the chemical compounds obtained. Orebom et al. [58] reported that in the liquefaction of black liquor, the yield of monocyclic aromatic compounds, such as phenols, cresols and mesitols, increased nearly linearly from $3 \mathrm{wt} . \%$ to $9 \mathrm{wt} . \%$ when the temperature increased from $613 \mathrm{~K}$ to $693 \mathrm{~K}$. They observed that the $\mathrm{pH}$ of the product decreased from 11 to $8-9$ as the reaction temperature increased from $613 \mathrm{~K}$ to $683 \mathrm{~K}$, whereby most of the phenols were transferred from the aqueous phase to bio-oil. Wahyudiono et al. [95] studied the effect of water density between $0.16 \mathrm{~g} / \mathrm{cm}^{3}$ to $0.67 \mathrm{~g} / \mathrm{cm}^{3}$ when alkaline lignin was treated in a batch reactor. The water density was adjusted by filling the batch reactor with different amounts of water before heating it to the target temperature. However, the amount of initial alkaline lignin $(0.1 \mathrm{~g})$ was 
kept constant, thus the concentration of alkaline lignin changed as the water amount was changed. The reaction temperature was between $623 \mathrm{~K}$ and $673 \mathrm{~K}$, while residence time ranged from 0 to $240 \mathrm{~min}$. The phenol yields with different reaction densities and reaction times at $623 \mathrm{~K}$ and $673 \mathrm{~K}$ are shown in Table 7. The phenol yield was found to increase with temperature, while increasing the pressure at a set temperature (increasing the density) led to a decrease of the phenol yield. In general, the yield of phenol, m-, p- and p-cresols increased at higher water densities (i.e., lower pressure) while the catechol yield decreased, especially under supercritical conditions. The authors assumed that the increasing density affects the ionic dissociation of water leading to enhanced hydrolysis of both the ether and carbon-carbon bonds. Under supercritical water conditions, liquid-like densities are required to enhance hydrolysis. However, the authors did not take account the effect of changing concentration of initial lignin. Therefore, it is difficult to distinguish the effect of concentration and density on the yield of different components.

Table 7. The phenol yield with different water densities and reaction times at $623 \mathrm{~K}$ and $673 \mathrm{~K}$. Data taken from Wahyudiono et al. [95].

\begin{tabular}{|c|c|c|c|c|c|c|c|}
\hline \multirow[t]{2}{*}{ Feedstock } & \multirow[t]{2}{*}{$\begin{array}{l}\text { Reaction } \\
\text { Condition }\end{array}$} & \multirow[t]{2}{*}{$\begin{array}{l}\text { Density } \\
\left(\mathrm{g} / \mathrm{cm}^{3}\right)\end{array}$} & \multicolumn{5}{|c|}{ Reaction Time } \\
\hline & & & $5 \mathrm{~min}$ & $15 \mathrm{~min}$ & $30 \mathrm{~min}$ & $60 \mathrm{~min}$ & $240 \mathrm{~min}$ \\
\hline \multirow{6}{*}{ Alkaline lignin } & \multirow{2}{*}{ Batch $623 \mathrm{~K}$} & 0.62 & 0.2 wt. $\%$ & 0.4 wt. $\%$ & 0.9 wt.\% & 1.3 wt. $\%$ & 2.5 wt. $\%$ \\
\hline & & 0.67 & 0.3 wt. $\%$ & 0.6 wt. $\%$ & 1.3 wt. $\%$ & 1.6 wt. $\%$ & 3.3 wt. $\%$ \\
\hline & \multirow{4}{*}{ Batch $673 \mathrm{~K}$} & 0.16 & 4.5 wt. $\%$ & 5.0 wt. $\%$ & 6.0 wt. $\%$ & 7.1 wt. $\%$ & 8.5 wt. $\%$ \\
\hline & & 0.35 & 4.5 wt. $\%$ & 5.5 wt. $\%$ & 6.3 wt. $\%$ & 7.5 wt. $\%$ & 10.2 wt. $\%$ \\
\hline & & 0.47 & 4.5 wt. $\%$ & 5.5 wt. $\%$ & 6.3 wt. $\%$ & 7.5 wt. $\%$ & 10.5 wt. $\%$ \\
\hline & & 0.52 & 4.5 wt. $\%$ & 6.1 wt. $\%$ & 8.0 wt. $\%$ & 8.0 wt. $\%$ & 11.8 wt. $\%$ \\
\hline
\end{tabular}

Lee et al. [106] studied the effect of temperature and residence time on the yield of monomeric aromatic chemicals (MAC) such as phenols, catechols, guaiacols and alkylated guaiacols. They noticed that the yield of certain MACs can be maximized by adjusting reaction temperature and residence time. For example, the highest catechol yield ( 1.6 wt.\%) was achieved at $623 \mathrm{~K}$ and $30 \mathrm{~min}$, while the highest homovanillic acid yield ( 2.1 wt. $\%$ ) was achieved at $573 \mathrm{~K}$ and $20 \mathrm{~min}$. The highest yield of total MAC ( $4.1 \mathrm{wt} . \%)$ was achieved at $623 \mathrm{~K}$ and at a residence time of $30 \mathrm{~min}$. A rise in temperature from $593 \mathrm{~K}$ to $633 \mathrm{~K}$ was found to increase the bio-oil heating value, and to decrease carbon yield and average molecular weight [120].

Nguyen et al. [107] observed in their study with LignoBoost co-fed with phenol and $\mathrm{K}_{2} \mathrm{CO}_{3}$ that raising the reaction temperature from $563 \mathrm{~K}$ to $643 \mathrm{~K}$ led to a gradual increase in the concentrations of anisoles, alkylphenols and catechols in the produced bio-oil up to $6.2 \mathrm{wt} . \%, 7.7 \mathrm{wt} . \%$ and $0.6 \mathrm{wt} . \%$ respectively. At the same time, the yields of guaiacols and phenolic dimers decreased (see Figure 8). The impact of the increase of temperature on the WSO fraction (see Figure 9) was similar, with the yields of catechols and alkyl phenols increasing in line with reaction temperature while the guaiacol yields decreased. A portion of the co-solvent (around 35-45 wt.\% of the initial phenol) was found to react with the intermediate products, which explains the variation in the phenol yield. As the reaction temperature increased from $563 \mathrm{~K}$ to $643 \mathrm{~K}$, the weight fractions of carbon and hydrogen increased, while the weight fractions of oxygen and sulfur decreased [107]. The weight fractions of $\mathrm{C}, \mathrm{H}, \mathrm{O}$ and $\mathrm{S}$ at $563 \mathrm{~K}$ were $70.0 \%, 6.5 \%, 21 \%, 0.41 \%$ respectively, while at $643 \mathrm{~K}$ the respective values were $76.0 \%$, $6.8 \%, 15 \%$ and $0.25 \%$. Similarly, the HHV of the product increased from $31.7 \mathrm{MJ} / \mathrm{kg}$ to $32.7 \mathrm{MJ} / \mathrm{kg}$. Therefore, the higher reaction temperature under these conditions increased deoxygenation of the product leading to a higher HHV. 


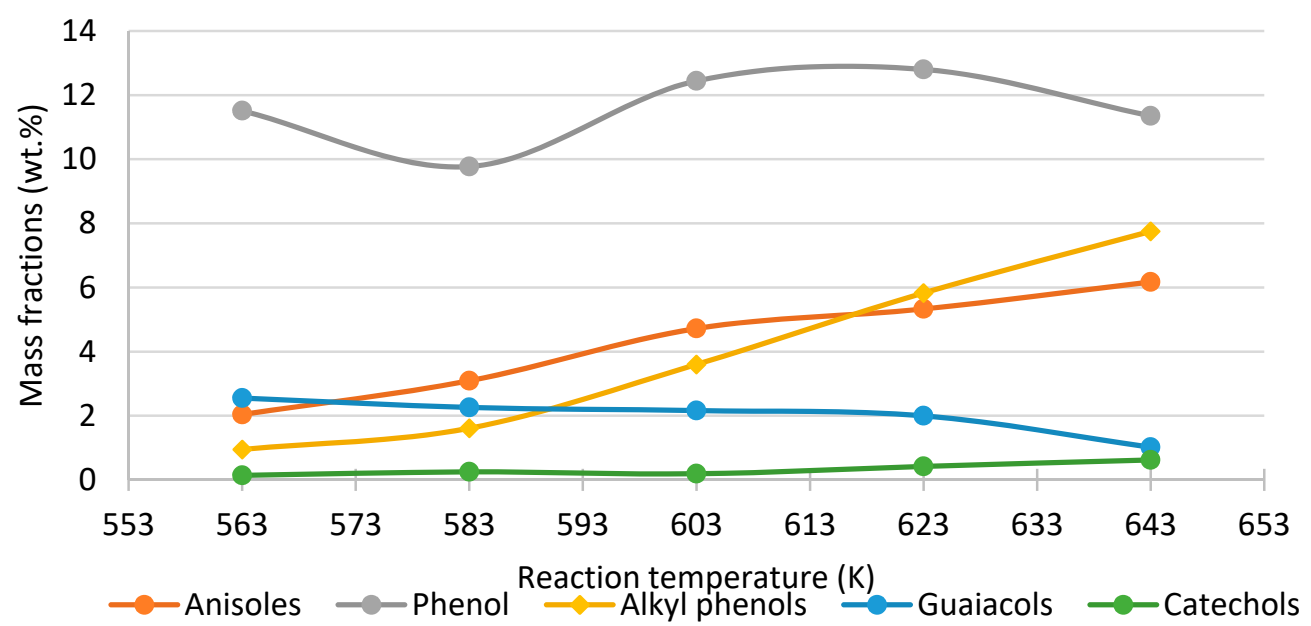

Figure 8. Effect of temperature on mass fractions of monocyclic aromatic compounds in bio-oil. Data is taken from [107]. The curves are guides to the eye.

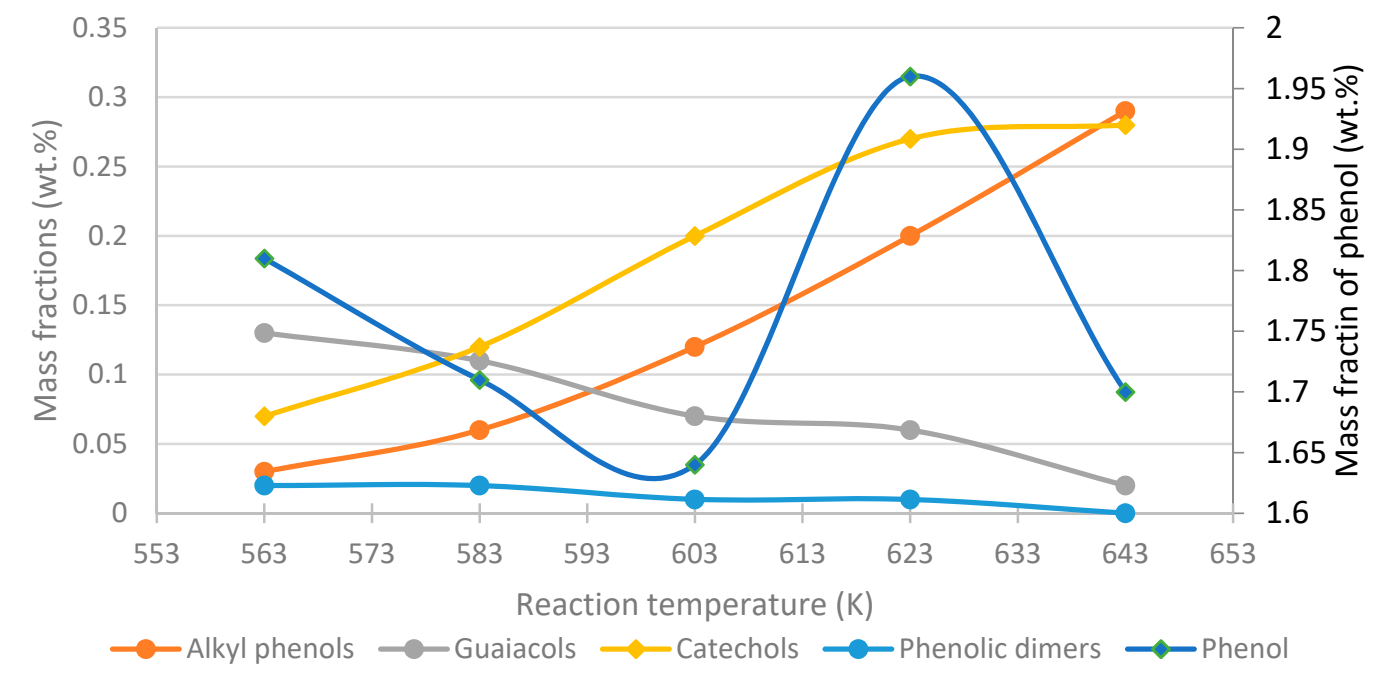

Figure 9. Effect of temperature on mass fractions of monocyclic aromatic compounds and phenolic dimers in WSO. Data is taken from [107]. The curves are guides to the eye.

Gas formation can be high in the HTL of weak black liquor under near- and supercritical water conditions. Sricharoenchaikul [121] studied the hydrothermal treatment of black liquor at a temperature range of $648 \mathrm{~K}$ to $923 \mathrm{~K}$ under pressures of $22 \mathrm{MPa}, 30 \mathrm{MPa}$ and $40 \mathrm{MPa}$. They noticed that treating black liquor at $648 \mathrm{~K}$ at a residence time of $2 \mathrm{~min}$ led to gas yields of $36 \mathrm{wt.} \%, 38 \mathrm{wt} . \%$ and $42 \mathrm{wt} . \%$ at $22 \mathrm{MPa}, 30 \mathrm{MPa}$ and $40 \mathrm{MPa}$, respectively. Similarly, the char yield decreased from ca. $30 \mathrm{wt} . \%$ to $20 \mathrm{wt} . \%$. At the temperature of $923 \mathrm{~K}$, the yield of gaseous compounds was ca. $76 \mathrm{wt} . \%$ at all pressures (22 $\mathrm{MPa}, 30 \mathrm{MPa}$ and $40 \mathrm{MPa}$ ). The main reported gaseous compounds present at the temperature of $773 \mathrm{~K}$ were $\mathrm{H}_{2}, \mathrm{CO}, \mathrm{CO}_{2}, \mathrm{CH}_{4}$ and $\mathrm{C}_{2}$ and $\mathrm{C}_{4}$ hydrocarbons. The concentrations of these gaseous compounds were fairly constant, corresponding to yields of approx. $5 \mathrm{wt} . \%$ for $\mathrm{CO}, 13 \mathrm{wt} . \%$ for $\mathrm{H}_{2}$, $8 \mathrm{wt} . \%$ for $\mathrm{CH}_{4}, 6 \mathrm{wt} . \%$ for $\mathrm{CO}_{2}, 15 \mathrm{wt} . \%$ for $\mathrm{C}_{2}$ and $7 \mathrm{wt} . \%$ for $\mathrm{C}_{4}$.

To summarize, temperature has a significant effect on the yield and quality of the bio-oil. High bio-oil yields are achieved both in near- and supercritical water. Generally, increasing temperature beyond the critical point enhances the degradation of lignin but it also increases repolymerization reactions between intermediate products and heavier compounds, such as char. Comparing the mass yields of bio-oils of different studies is challenging due to the lack of homogeneity in how the mass yields are expressed. The effect of temperature on bio-oil yield is obscured by variations in other 
parameters, such as the feed used, the salts present, the use of additives or the pressure. What is clear is that as temperature will impact the kinetics of various reactions, adjusting both the temperature and residence time is critical to reach a high yield of certain compounds, such as alkyl phenols.

Overall, the literature does indicate the following trends for the impact of pressure and temperature on the process:

- An increase in temperature leads to higher HHV of the bio-oil due to both a decrease in the oxygen weight fraction and the increased weight fractions of carbon and hydrogen.

- Phenol, cresol, alkylphenol yields increase with increasing temperature, while the yield of guaiacol decreases, regardless of the process conditions and feed composition.

- An increase of pressure at a set temperature will lead to an increase of phenols and cresol as a result of favored hydrolysis (higher water density).

- As for any type of feed, a decrease in water density (increase of temperature or decrease of pressure) will significantly increase the gas yield and decrease the formation of tars/chars.

- The effect of water density in the HTL of lignin has not yet been widely studied, even though it greatly affects the dissociation of lignin. Under supercritical water conditions, liquid-like densities appear to be one way to influence the product distribution and, therefore, the effect of water density on the HTL of black liquor should be studied further.

\subsubsection{The Effects of Residence Time}

Residence time has to be long enough to ensure the degradation of lignin into its monomers, yet not so long that it leads to increased amounts of gaseous compounds or char. Optimizing both the yield and quality of bio-oil is challenging because the reaction mechanisms of the HTL process include serial and parallel reactions that are dependent on the reaction conditions. Figure 10 shows the bio-oil yields as a function of residence time from various studies. The widely differing bio-oil yields of Orebom et al. [58] and Lee et al. [106] can be explained by the raw material used in the experiments, as well as the different expressions for the bio-oil yield and differences in the experimental set-ups.

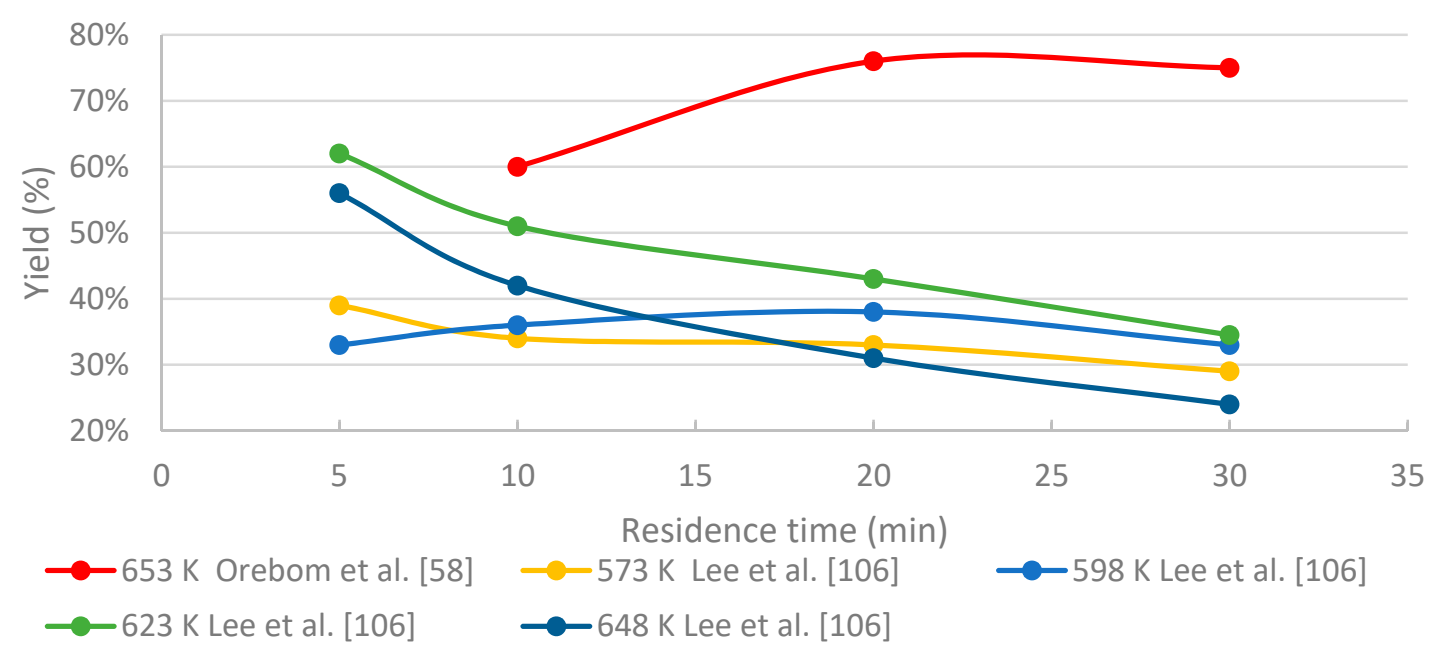

Figure 10. Bio-oil yield as a function of residence time. All the experiments were performed in batch reactors. The curves are guides to the eye.

Orebom et al. [58] studied the degradation of fresh black liquor (DM 5 wt.\%) in a batch reactor at $653 \mathrm{~K}$ with a residence time of between $5 \mathrm{~min}$ and $240 \mathrm{~min}$. A maximum bio-oil yield of $76 \mathrm{wt} . \%$ was achieved at a residence time of $20 \mathrm{~min}$ while the yield slightly decreased to ca. $68 \mathrm{wt} . \%$ when the experiment was extended up to $120 \mathrm{~min}$. The char yield remained relatively stable at between $8 \mathrm{wt} . \%$ and $10 \mathrm{wt} . \%$ while the residence time ranged from $10 \mathrm{~min}$ to $120 \mathrm{~min}$ (see Figure 11). The yield of monomers was also relatively stable, being $4 \mathrm{wt} . \%$ at $30 \mathrm{~min}$ and $5 \mathrm{wt} . \%$ at $60 \mathrm{~min}$. However, 
Orebom et al. [58] did not report any data on the composition or $H H V$ for bio-oils obtained at different residence times. This makes it impossible to estimate the effect of residence time on the energy recovery from feedstock to bio-oil. Lee et al. [106] studied the effect of residence time (between $5 \mathrm{~min}$ and $30 \mathrm{~min}$ ) on the degradation of Kraft lignin at temperatures from $573 \mathrm{~K}$ to $648 \mathrm{~K}$ and at a pressure of $30 \mathrm{MPa}$. Above a reaction temperature of ca. $620 \mathrm{~K}$, a short residence time of $5 \mathrm{~min}$ is favorable for the bio-oil yields (ca. $60 \mathrm{wt} . \%$ ), but this quickly decreases to reach ca. $30 \mathrm{wt} . \%$ for a 30 -min residence time. For the experiments below $600 \mathrm{~K}$, the trend is less obvious (see Figure 10) but is overall more stable over residence times ranging from $5 \mathrm{~min}$ to $30 \mathrm{~min}$ as the yields remained between $30 \mathrm{wt} . \%$ and $40 \mathrm{wt} . \%$. The highest bio-oil yield was ca. $62 \mathrm{wt} . \%$, achieved with a residence time of $5 \mathrm{~min}$ at $623 \mathrm{~K}$.

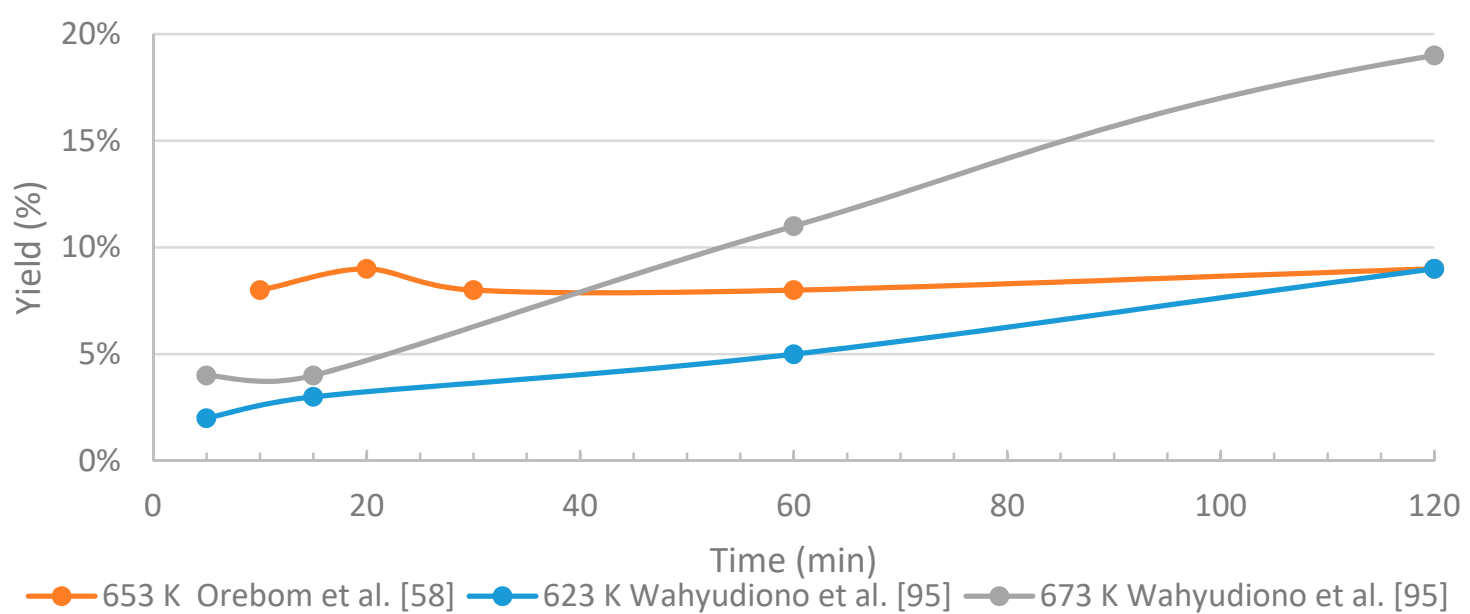

Figure 11. The influence of residence time on char yield. All the experiments were performed in batch reactors. The curves are guides to the eye.

Wahyudiono et al. [95] studied the HTL of alkaline lignin in a batch reactor for residence times between $5 \mathrm{~min}$ and $240 \mathrm{~min}$ (includes heating time of ca. $3 \mathrm{~min}$ ) at temperatures of $623 \mathrm{~K}$ and $673 \mathrm{~K}$ and pressure between 25 and $40 \mathrm{MPa}$. The products in the bio-oil were separated into methanol-insoluble (MI) and methanol-soluble (MS) fractions. The researchers assumed that lignin first depolymerizes, and then the depolymerized intermediate products react further via hydrolysis, dealkylation and repolymerization reactions. Hydrolysis and dealkylation reactions produce the MS fraction, which includes compounds such as catechols, phenols, cresols. The MI fraction was assumed to be char, since the feedstock, i.e., alkaline lignin, dissolved completely into methanol. They assumed that the formation of char is due to condensation reactions between low molecular weight compounds producing high molecular weight compounds. When the residence time was extended from $5 \mathrm{~min}$ to $240 \mathrm{~min}$, the amount of MI fraction increased from $2 \mathrm{wt} . \%$ to $16 \mathrm{wt} . \%$ at $623 \mathrm{~K}$ and from $6 \mathrm{wt} . \%$ to $25 \mathrm{wt} . \%$ at $673 \mathrm{~K}$. At $623 \mathrm{~K}$, the catechol yield achieved its maximum value of $30 \mathrm{wt} . \%$ at $30 \mathrm{~min}$ residence time and decreased to ca. $20 \mathrm{wt} . \%$ at $240 \mathrm{~min}$. At $673 \mathrm{~K}$, catechol yields were overall lower, and their decrease with increasing residence time was much more pronounced, e.g., ca. $1 \mathrm{wt} . \%$ yield was reached after $240 \mathrm{~min}$. An increase in the residence time from 5 to $120 \mathrm{~min}$ at both temperatures led to increasing yields of phenol and cresols, after which their yields remained fairly stable. In concluding their study, Wahyudiono et al. [95] proposed that it is possible to both maximize the yield of certain compounds, such as phenol, and minimize the formation of char by using short residence times under near- and supercritical conditions.

To summarize, residence times should be around $20 \mathrm{~min}$ for near-critical and supercritical water conditions. However, it seems like that the use of shorter residence time under subcritical conditions may lead to higher yield of bio-oil. Longer residence times led to decreasing bio-oil yields due to condensation reactions or the gasification of the light organic compounds formed.

In short, the following general rules apply: 
- To maximize the yield of certain compounds, such as phenol/catechol, a compromise between temperature and residence time is required.

- Higher temperatures are favorable for producing high bio-oil yields, whereas residence time needs to be reduced significantly to prevent both gasification and char formation.

\subsubsection{The Effect of the Dry Matter Content of the Feedstock}

The product from the HTL of black liquor is also affected by the dry matter concentration of the feedstock. However, the initial black liquor concentration is one parameter that has not been widely studied. Orebom et al. [58] studied the effect of various fresh black liquor concentrations. The initial lignin content was varied from $5 \mathrm{wt} . \%$ up to $18 \mathrm{wt} . \%$ with a residence time of $1 \mathrm{~h}$ at $653 \mathrm{~K}$. When the lignin concentration increased from $5 \mathrm{wt} . \%$ to $18 \mathrm{wt} . \%$, the bio-oil yield decreased from around $73 \mathrm{wt} . \%$ to $58 \mathrm{wt} . \%$, while the char yield increased from $8 \mathrm{wt} . \%$ to $40 \mathrm{wt} . \%$. The authors noticed that adding an aliphatic alcohol (ethanol) reduced the char yield when the experiments were made with the initial lignin concentration of $18 \mathrm{wt} . \%$ and the residence time of $1 \mathrm{~h}$. Without ethanol the char yield was $27.5 \mathrm{wt} . \%$ but it decreased significantly to $9.6 \mathrm{wt} . \%$ with an initial ethanol concentration of $10 \mathrm{wt} . \%$. However, it was unclear whether they diluted the lignin content by adding $10 \mathrm{wt} . \%$ of ethanol or the lignin content was kept constant.

A high initial lignin concentration appears to both decrease the bio-oil yield and increase the char yield. The increase in char yield is almost directly proportional to the increasing amount of lignin in the initial feedstock. Therefore, a low initial lignin concentration ( $5 \mathrm{wt} . \%)$ should be used in order to keep the char yield low. The addition of aliphatic alcohol (e.g., ethanol) as a co-solvent significantly reduced char formation; however, it was clear whether the decreased formation of was partly due to the dilution of the lignin content.

\subsection{The Performance of the Catalysts}

Catalysts are either homogeneous or heterogeneous. Homogeneous catalysts are preferable when treating black liquor in an HTL process. It is in the nature of the process that black liquor naturally contains homogeneous catalysts (see Table 2) and the studies reported here all concern the addition of salts naturally present in black liquor to black liquor-derived lignin (see Table 8). The heterogeneous catalysts tested for improving the HTL of alkaline lignin were zirconia-, nickel-, ruthenium and lead-based catalysts $[109,113]$. With the exception of $\mathrm{ZrO}_{2}$, either Activated Carbon (AC) or $\mathrm{Al}_{2} \mathrm{O}_{3}$ was used as a catalyst support for all the catalysts. Note, however, that black liquor contains alkali salts and sulfides that can both deactivate and/or foul the active surface of heterogeneous catalysts.

Table 8. Effects of various catalyst materials.

\begin{tabular}{ccccccccc}
\hline Feed & Catalysts & $\begin{array}{c}T \\
(\mathrm{~K})\end{array}$ & $\begin{array}{c}\boldsymbol{P} \\
(\mathbf{M P a})\end{array}$ & Solvents & $\begin{array}{c}\text { Max bio-Oil } \\
\text { Yield }\end{array}$ & Optimal Catalyst & $\begin{array}{c}\text { Reac-tion } \\
\text { Time }\end{array}$ & Ref \\
\hline $\begin{array}{c}\text { Ligno-boost } \\
\text { lignin }\end{array}$ & $\begin{array}{c}\mathrm{K}_{2} \mathrm{CO}_{3}, \mathrm{KOH}, \\
\mathrm{Na}_{2} \mathrm{CO}_{3}, \\
\mathrm{NaOH}_{2}\end{array}$ & 623 & 25 & $\begin{array}{c}\text { Phenol } \\
4 \mathrm{wt} \%\end{array}$ & $73.8 \mathrm{wt} . \%$ & $\begin{array}{c}\mathrm{Na} /(\mathrm{Na}+\mathrm{K}) \mathrm{ratios} \\
\text { of } 0 \text { and } 1.0\end{array}$ & $6 \mathrm{~min}$ & {$[113]$} \\
$\begin{array}{c}\text { Ligno-boost } \\
\text { lignin }\end{array}$ & $\begin{array}{c}\mathrm{K}_{2} \mathrm{CO}_{3}, \mathrm{ZrO}_{2} \\
\text { (pellets) }\end{array}$ & 623 & 25 & $\begin{array}{c}\text { Phenol } \\
4.0-4.7 \mathrm{wt} . \%\end{array}$ & $72.2 \mathrm{wt} \%$ & $\mathrm{~K}_{2} \mathrm{CO}_{3} 1.6 \mathrm{wt} \%$ & $11 \mathrm{~min}$ & {$[114]$} \\
\hline
\end{tabular}

Black liquor mainly contains salts (see Table 3) where sodium is the cation, but there are small amounts of potassium salts which come from the biomass (between $0.7 \mathrm{~kg}$ and $4 \mathrm{~kg}$ per ton of air-dry pulp produced [122]). Due to the chemical cycle in the Kraft process, potassium accumulates and can cause several problems in the recovery boiler. Many studies related to the HTL of biomass have proved that alkali salts enhance the WGS reaction and stabilize the intermediate products, and prevent the formation of char $[56,103,104,123]$.

Belkheiri et al. [113] studied the effect of changing the molecular ratio of $\mathrm{Na}^{+} /\left(\mathrm{Na}^{+}+\mathrm{K}^{+}\right)$in the HTL of LignoBoost Lignin in a continuous reactor at $623 \mathrm{~K}$ and $25 \mathrm{MPa}$ at $6 \mathrm{~min}$. They used $\mathrm{NaOH}$, 
$\mathrm{Na}_{2} \mathrm{CO}_{3}, \mathrm{KOH}$ and $\mathrm{K}_{2} \mathrm{CO}_{3}$ to adjust the molecular ratio of the $\mathrm{Na}^{+} /\left(\mathrm{Na}^{+}+\mathrm{K}^{+}\right)$. The molecular ratio of the anions, i.e., $\mathrm{OH}^{-}$and $\mathrm{CO}_{3}{ }^{2-}$, were kept constant during the experiments. When the molecular ratio increased from 0.0 to 1.0, the yields for the bio-oil fraction varied between $65.4 \mathrm{wt} . \%$ and $73.8 \mathrm{wt} . \%$, for the WSO fraction between $11.4 \mathrm{wt} . \%$ and $19.3 \mathrm{wt} . \%$, and for the char fraction, by between $13.9 \mathrm{wt} . \%$ and $15.3 \mathrm{wt} . \%$. Interestingly, the highest bio-oil yield was achieved when only $\mathrm{Na}^{+}$was used, but nearly similar bio-oil yields were achieved with the two lowest molecular ratios of $\mathrm{Na}^{+} /\left(\mathrm{Na}^{+}+\mathrm{K}^{+}\right)(0.0$ and 0.5). The yields of the WSO and char fractions did not significantly change when either sodium or potassium were used, although the yield of WSO slightly increased from ca. $12 \mathrm{wt} . \%$ up to $19.3 \mathrm{wt} . \%$ in the presence of both cations. The most notable change was found in the amounts of the heavy oil and suspended solids (SS) in the bio-oil fraction. Increasing the ratio of $\mathrm{Na}^{+} /\left(\mathrm{Na}^{+}+\mathrm{K}^{+}\right)$from 0.8 to 1.0 decreased the amount of SS from $12.0 \mathrm{wt} . \%$ to $3.8 \mathrm{wt} . \%$, while at the same time the amount of heavy oil increased from $22.4 \mathrm{wt} . \%$ to $37.6 \mathrm{wt} . \%$. Similarly, the amount of light oil in the total bio-oil yield decreased from $65.6 \mathrm{wt} . \%$ to $58.6 \mathrm{wt} . \%$. With lower ratios of $\mathrm{Na}^{+} /\left(\mathrm{Na}^{+}+\mathrm{K}^{+}\right)$, the yields of both heavy oil and SS fractions remained relatively stable. This significant growth in the heavy oil yield and the drop in the yield of suspended solids when changing from sodium salts to potassium salts may be related to the salt's behavior (see Table 4), which leads to changes in its concentration in the fluid. The key observation was that the recovery of potassium and sodium in the aqueous fraction were $94 \mathrm{wt.} \%$ and $91 \mathrm{wt} . \%$ respectively [113]. The aqueous fraction could be returned to the Kraft process whereby most of the cooking chemicals could be recovered.

Nguyen et al. [114] studied the HTL of LignoBooost lignin with various initial concentrations of $\mathrm{K}_{2} \mathrm{CO}_{3}$ at $623 \mathrm{~K}$ and $25 \mathrm{MPa}$ with a residence time of $11 \mathrm{~min}$. Phenol was used as a co-solvent (4.1 wt.\% of the initial feed) and $\mathrm{ZrO} 2$ pellets were used in a continuous process. The yields of bio-oil, WSO and char were relatively stable as the initial $\mathrm{K}_{2} \mathrm{CO}_{3}$ concentration rose from $0.4 \mathrm{wt} . \%$ to $2.2 \mathrm{wt} . \%$. The yields were $69.4-72.2 \mathrm{wt} . \%$ for bio-oil, 8.7-10.8 wt.\% for WSO, and 17.2-20.7 wt.\% for char. However, increasing the initial $\mathrm{K}_{2} \mathrm{CO}_{3}$ concentration from $0.4 \mathrm{wt} . \%$ to $2.2 \mathrm{wt} . \%$ did significantly affect the proportion of suspended solids in the bio-oil fraction, which increased from $0.1 \mathrm{wt} . \%$ to $22.9 \mathrm{wt} . \%$. A significant change took place when studying the total yield of phenolic compounds such as anisoles and alkylphenols. Raising the initial $\mathrm{K}_{2} \mathrm{CO}_{3}$ concentration from $0.4 \mathrm{wt} . \%$ to $2.2 \mathrm{wt} . \%$ increased the yield of 1-phenolic compounds from $16.9 \mathrm{wt} . \%$ to $27.1 \mathrm{wt} . \%$. Although the elemental composition of the bio-oil did not change significantly with different initial concentrations of $\mathrm{K}_{2} \mathrm{CO}_{3}$, the amount of ash in the bio-oil increased from $1.0 \mathrm{wt} . \%$ to $3.5 \mathrm{wt} . \%$, when the initial concentration of $\mathrm{K}_{2} \mathrm{CO}_{3}$ increased from $0.4 \mathrm{wt} . \%$ to $2.2 \mathrm{wt} . \%$.

Melin et al. [116] studied the HTL of black liquor with a dry matter content of $30.8 \mathrm{wt} . \%$, treated for $45 \mathrm{~min}$ at $623 \mathrm{~K}$. Either sodium hydroxide or sodium carbonate were added to the black liquor and glycerol was added as a char-reducing agent. When $13.2 \mathrm{wt} . \% \mathrm{Na}_{2} \mathrm{CO}_{3}$ was added to the dry matter of the black liquor, they observed a maximum carbon yield of approximately $69 \%$ and a bio-oil $\mathrm{HHV}$ of $26 \mathrm{MJ} / \mathrm{kg}$ on an as-received basis, rising to $36.6 \mathrm{MJ} / \mathrm{kg}$ on a dry ash-free basis. When $10 \% \mathrm{wt} . \%$ (an equal amount of alkali compared to $\mathrm{Na}_{2} \mathrm{CO}_{3}$ ) sodium hydroxide of the black liquor's dry matter was added, the carbon yield rose from $61 \%$ to $64 \%$ compared to when no $\mathrm{NaOH}$ was added, while the bio-oil HHV on an as-received basis was $25 \mathrm{MJ} / \mathrm{kg}$ and $34.2 \mathrm{MJ} / \mathrm{kg}$ on a dry ash-free basis. When $\mathrm{Na}_{2} \mathrm{CO}_{3}$ was added to the feedstock, a solid product was observed in the aqueous phase after reaction, but this was not observed when $\mathrm{NaOH}$ was added. A higher $\mathrm{NaOH}$ concentration of $25 \mathrm{wt} . \%$ of the black liquor dry matter content reduced the carbon yield from $61 \%$ from $54 \%$ compared to the $10 \mathrm{wt} . \%$ addition [116,124].

Belkheiri et al. [115] studied the effect of various $\mathrm{KOH}$ concentrations on the yields of different fractions in a continuous working fixed catalytic bed $\left(\mathrm{ZrO}_{2}\right)$ HTL plant, where Kraft lignin (dry matter content $5.5 \mathrm{wt} . \%$ ) was treated in water at $623 \mathrm{~K}$ and $25 \mathrm{MPa}$. The $\mathrm{KOH}$ concentrations varied between $0.0 \mathrm{wt} . \%$ and $2.0 \mathrm{wt} . \%$, and they also added $\mathrm{K}_{2} \mathrm{CO}_{3}$ and phenol to the feedstock. Their study focused on the effects of $\mathrm{pH}$ on the HTL of Kraft lignin, although $\mathrm{KOH}$ does not only affect the $\mathrm{pH}$ of the feed. $\mathrm{KOH}$ acts as a catalyst in the HTL process, so it is impossible to distinguish the effect of $\mathrm{pH}$ alone 
from this experiment. The $\mathrm{KOH}$ concentration of the feed between $0.0 \mathrm{wt} . \%$ and $2.2 \mathrm{wt} . \%$ led to a variation in the bio-oil yield of between $27 \mathrm{wt} . \%$ and $42 \mathrm{wt} . \%$, while the WSO yield increased almost linearly from $24 \mathrm{wt} . \%$ to $40 \mathrm{wt} . \%$. The amount of phenol in light oil fraction remained stable at ca. $40 \mathrm{wt} . \%$ when the $\mathrm{KOH}$ concentration of the feed was between $0.0 \mathrm{wt} . \%$ and $0.8 \mathrm{wt} . \%$, whereas it decreased from $42 \mathrm{wt} . \%$ to $35 \mathrm{wt} . \%$ as the concentration increased up to $2 \mathrm{wt} . \%$. Leaving aside the catalytic effects of the salts used, it can be assumed that the increasing yield of the WSO fraction was simply due to the transfer of small phenolic compounds from the bio-oil fraction to the WSO fraction as the $\mathrm{pH}$ rises as a result of the increasing of $\mathrm{KOH}$ addition. Indeed, the pKa value of the phenolic compounds is mainly between 9.5 and 10.5, so higher $\mathrm{pH}$ values lead to an increase in the amount of ionized phenolic compounds that are hydrophilic. The minimum char yield was achieved with an initial $\mathrm{KOH}$ concentration of $0.4 \mathrm{wt} . \%$, when its yield was around $13 \mathrm{wt} . \%$. Either lowering or increasing the $\mathrm{KOH}$ concentration of the feed would increase the char yield. The authors presumed that a higher $\mathrm{pH}$ enhances repolymerization reactions, especially when the $\mathrm{pH}$ of the feed is above 9.5 (initial $\mathrm{KOH}$ concentration is higher than $0.4 \mathrm{wt} . \%$ ). This was supported by their findings, which showed that the amount of suspended solids (SS) in bio-oil increased from ca. $9 \mathrm{wt} . \%$ up to $35 \mathrm{wt} . \%$ when the $\mathrm{pH}$ increased from 9.5 to 10.4 , corresponding to initial $\mathrm{KOH}$ concentrations of from $0.4 \mathrm{wt} . \%$ to $2.0 \mathrm{wt} . \%$. However, the catalytic effect of $\mathrm{KOH}$ may have a greater influence on the SS yields, as observed in another study by Belkheiri et al. [113] where the change from sodium salts to potassium salts led to higher SS yields. The $\mathrm{KOH}$ concentration of the feed influences the concentration of the organic compounds in the WSO and bio-oil fractions (see Figure 12). There were some notable changes in the elemental composition of the bio-oil fraction as the initial $\mathrm{KOH}$ concentration increased from $0.0 \mathrm{wt} . \%$ to $2.0 \mathrm{wt} . \%$. The oxygen content decreased from $17.3 \mathrm{wt} . \%$ to $13.8 \mathrm{wt} . \%$, while the ash content increased from $1.4 \mathrm{wt} . \%$ to $4.2 \mathrm{wt} . \%$. Similarly, the amount of sodium in the bio-oil increased from 64 ppm to 200 ppm.
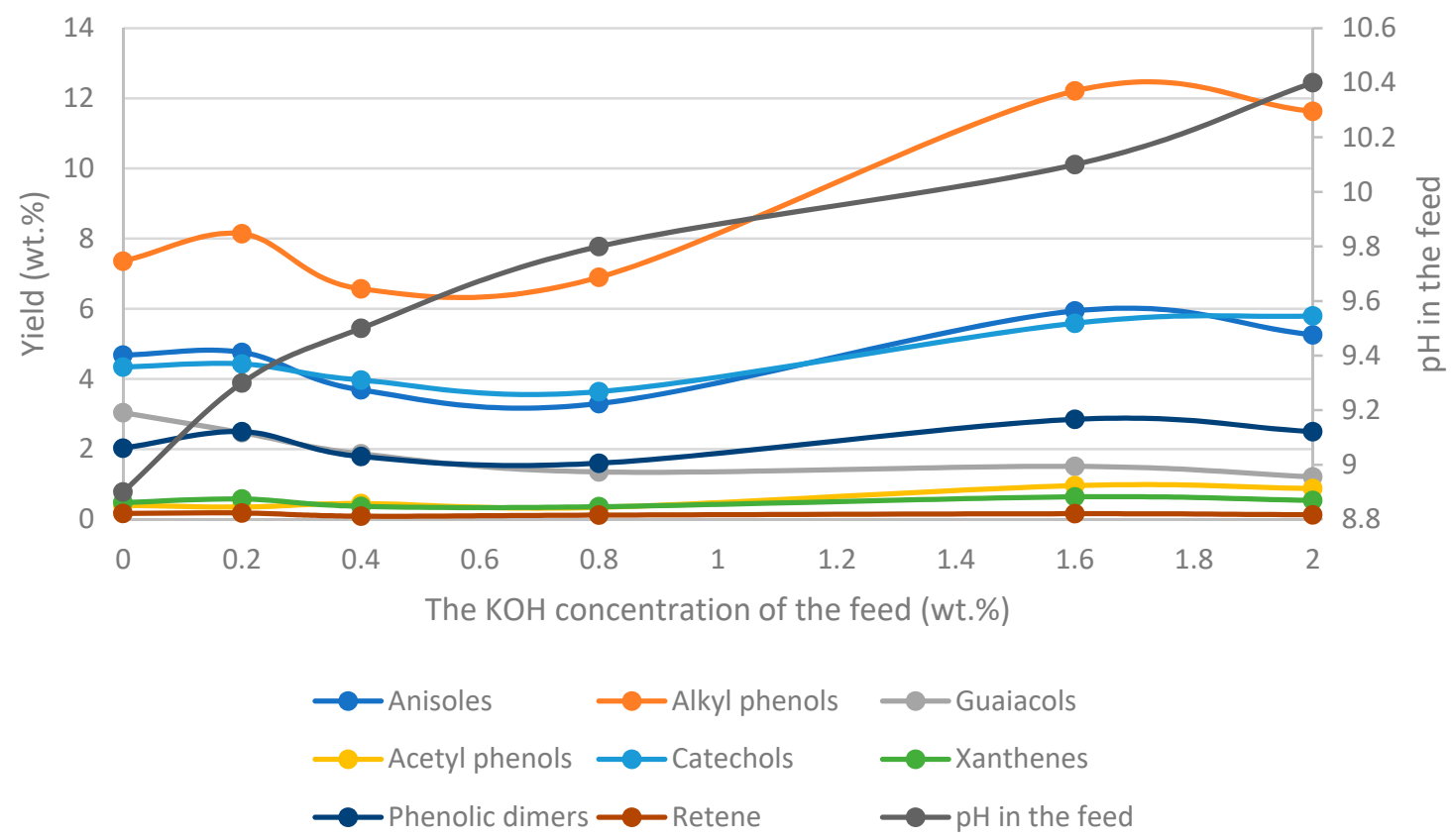

Figure 12. Effect of the initial $\mathrm{KOH}$ concentration on the total yields (both WSO and bio-oil) of various components. The feedstock for the HTL process was Kraft lignin. The curves are guides to the eye. Data is taken from Belkheiri et al. [115].

Peng et al. [125] studied the effects of various alkali salts $\left(\mathrm{NaOH}, \mathrm{Na}_{2} \mathrm{CO}_{3}, \mathrm{KOH}, \mathrm{K}_{2} \mathrm{CO}_{3}\right)$ on alkali lignin in a batch reactor at $573 \mathrm{~K}$ and $8.5 \mathrm{MPa}$. They studied the effects of these separately by adding the same amount ( 0.0125 moles) of alkali salts to the feedstock. They noticed that weak 
alkali salts $\left(\mathrm{Na}_{2} \mathrm{CO}_{3}\right.$ and $\left.\mathrm{K}_{2} \mathrm{CO}_{3}\right)$ enhanced decarboxylation and demethoxylation reactions, leading to higher catechol yields. On the other hand, strong alkali salts including hydroxy anions improved the deoxygenation reactions leading to higher amounts of phenols and cresols.

When treating black liquor, the use of many transition metals like $\mathrm{Ni}$, $\mathrm{Ru}$ or $\mathrm{Pt}$ in their reduced form is made impossible by the presence of a high concentrations of sulfur in the form of sulfides. Indeed, black liquor contains a large amount of cooking salts, such as $\mathrm{Na}_{2} \mathrm{~S}$, whose anion (sulfide $\mathrm{S}^{2-}$ ) readily poisons such catalysts, as do the organosulfur compounds [126]. In addition, many catalyst supports are unstable under both alkali and sub- or supercritical water conditions [127]. Certain compatible oxides on activated carbon or catalysts based on sulfide metals are the best candidates for the catalytic liquefaction of black liquor, but knowledge about heterogeneous catalysis in this area remains rare.

Belkheiri et al. [113] studied the effect of zirconium oxide as a heterogeneous catalyst on the HTL of LignoBoost lignin. The result of experiments with a solid zirconia catalyst was compared with the results from experiments with glass beads. The study was conducted at $623 \mathrm{~K}$ and $25 \mathrm{MPa}$ with initial concentrations of phenol and $\mathrm{K}_{2} \mathrm{CO}_{3}$ of $4.1 \mathrm{wt} . \%$ and $1.6 \mathrm{wt} . \%$, respectively, and with a short residence time of $6 \mathrm{~min}$. The yield of light oil in the bio-oil fraction was $15.9 \mathrm{wt}$.\% with the zirconia catalyst, while it was only $8.4 \mathrm{wt} . \%$ with glass beads. They assumed that zirconia could act as a catalyst for enhancing reactions that produce smaller molecular-weight organic compounds, but the nature of the active sites or the mechanisms involved remains unclear. In addition, sulfur species do not deactivate $\mathrm{ZrO} 2$ because sulfidation of this oxide is not favored [128]. Cheng et al. [109] studied the degradation of alkaline lignin at $573 \mathrm{~K}$ in water-ethanol (50/50 ratio) for $2 \mathrm{~h}$. They investigated the effect of five different catalysts, i.e., $\mathrm{Ni}_{10} / \mathrm{Al}_{2} \mathrm{O}_{3}, \mathrm{Ru}_{10} / \mathrm{Al}_{2} \mathrm{O}_{3}, \mathrm{Pt}_{10} / \mathrm{AC}, \mathrm{Ru}_{10} / \mathrm{AC}$ and $\mathrm{Ni}_{10} / \mathrm{AC}$. The yields of degraded lignin were $62.5 \mathrm{wt} . \%$ for $\mathrm{Ni}_{10} / \mathrm{Al}_{2} \mathrm{O}_{3}, 66.3 \mathrm{wt}$ \% $\%$ for $\mathrm{Ru}_{10} / \mathrm{Al}_{2} \mathrm{O}_{3}, 77.1 \mathrm{wt} . \%$ for $\mathrm{Pt}_{10} / \mathrm{AC}$, $89.4 \mathrm{wt} . \%$ for $\mathrm{Ru}_{10} / \mathrm{AC}$ and $84.1 \mathrm{wt} . \%$ for $\mathrm{Ni}_{10} / \mathrm{AC}$, while they were $88.5 \mathrm{wt} . \%$ without any catalyst. Forchheim et al. [129] evaluated that Raney Nickel increases the selectivity toward phenols because it supports the conversion from catechol to phenol.

Several homogeneous catalysts, such as $\mathrm{Na}_{2} \mathrm{CO}_{3}, \mathrm{NaOH}$ or $\mathrm{Na}_{2} \mathrm{~S}$ are naturally present in black liquor. Indeed, the first two (Na- or K-based) are known in the HTL community as efficient catalysts for improving both the yield and quality of bio-oil from the HTL of lignin-based sources. While $\mathrm{K}_{2} \mathrm{CO}_{3}$ is a widely used catalyst in HTL processes, potassium salts are a danger in the recovery boiler, because potassium lowers the melting points of the salts in the boiler and, in addition, potassium salts (for example, potassium chloride) are generally more volatile than sodium salts [130]. Thus, they travel with the dust to various surfaces of the recovery boiler, such as surfaces of superheaters, causing fouling and corrosion [130]. Belkheiri et al. [113] reported a similar bio-oil yield when only sodium salts were used as a catalyst in the HTL of LignoBoost Lignin, compared to a similar experiment with potassium salts [113].

In summary, the various studies performed on black liquor HTL come down to the following points:

- Potassium carbonate increases the presence of suspended solids in the bio-oil and favors the yields of phenolic compounds.

- $\quad$ Adjusting the $\mathrm{Na} / \mathrm{K}$ ratio for a $\mathrm{CO}^{2-}$ and $\mathrm{HO}$ - mixture gives led to similar yields of bio-oils but affects product yields at a high $\mathrm{Na} / \mathrm{K}$ ratio. On the other hand, a high ratio decreases the amounts of suspended solids (SS) in the oil and increases the proportion of heavy oil.

- Alkali salts catalyzes decarboxylation and demethoxylation reactions. In addition, alkali salts with hydroxy anions enhance deoxygenation reactions.

- Homogeneous catalysts (alkali salts) naturally present in BL affect product yields and composition, but also affect the ash-content in the bio-oil, which increases with increasing salt concentration.

- The $\mathrm{pH}$ of the feedstock and product will affect the composition of the bio-oil and the aqueous phase (WSO) as weak acids, such as phenols, may become deprotonated. The final $\mathrm{pH}$ will depend on the process parameters. 
- Of the few compatible heterogeneous catalysts that are compatible with the high-pH sulfur-rich feed of black liquor, only zirconia $\left(\mathrm{ZrO}_{2}\right)$ has been studied. Although this appears to impact the quality of the bio-oil, the understanding of the mechanism is very limited. Bearing in mind that the high concentration of salts in black liquor may foul (see Section 3.2) and hence deactivate the catalysts, much research still remains to be done into heterogeneous catalysis with black liquor.

\subsection{The Role of Co-Solvents}

Co-solvents can be added to black liquor upon treatment under sub- and supercritical conditions to impact the bio-oil yield, and the char and gas formation. Some solvents can work as hydrogen donors, some can act as hydrogen acceptors, whereas some do not take part in the reactions at all [131]. Most of the experiments reported here were performed with solvents that act as hydrogen donors. They are assumed to stabilize the free radicals formed during the degradation of the biomass and to favor deoxygenation and hydrogenolysis reactions [132]. Typical hydrogen donor additives are alcohols such as glycerol, ethanol or phenol. For its aromaticity, phenol offers good control of cross-linking (radical) reactions between intermediate products (repolymerization), as it reacts with the intermediates to form more stable ones [133]. For that reason, it is often referred to as a "capping agent".

Cheng et al. [109] and Lee et al. [106] studied the effect of various initial ethanol concentrations when black liquor-derived lignin was treated under subcritical water conditions (see Table 9).

Table 9. Summary of HTL experiments with ethanol as co-solvent.

\begin{tabular}{|c|c|c|c|c|c|c|c|c|c|}
\hline Feed-stock & & & & & & & & & Ref \\
\hline \multirow[b]{2}{*}{$\begin{array}{l}\text { Alkali lignin } \\
\text { (from Sigma- } \\
\text { Aldrich) }\end{array}$} & $\begin{array}{l}\text { Reaction } \\
\text { condition }\end{array}$ & Solvent & Ethanol (vol\%) & 0 & 25 & 50 & 75 & 100 & \multirow[b]{2}{*}{ [109] } \\
\hline & $\begin{array}{l}\text { Batch, } \\
573 \mathrm{~K}, \\
4 \mathrm{~h}\end{array}$ & Yield (wt.\%) & $\begin{array}{c}\text { Degraded lignin } \\
\text { Water soluble product } \\
\text { Solid residue } \\
\text { Total gas }\end{array}$ & $\begin{array}{c}49.0 \\
8.0 \\
13.0 \\
2.0 \\
\end{array}$ & $\begin{array}{c}51.0 \\
10.0 \\
25.0 \\
6.0\end{array}$ & $\begin{array}{c}87.0 \\
4.0 \\
2.0 \\
4.0 \\
\end{array}$ & $\begin{array}{c}48.0 \\
5.0 \\
31.0 \\
5.0\end{array}$ & $\begin{array}{c}15.0 \\
10.0 \\
55.0 \\
3.0\end{array}$ & \\
\hline \multirow{5}{*}{$\begin{array}{l}\text { Kraft lignin } \\
\text { (from } \\
\text { Sigma-Aldrich) }\end{array}$} & $\begin{array}{l}\text { Reaction } \\
\text { condition }\end{array}$ & Solvent & $\begin{array}{l}\text { Water-to-Ethanol ratio } \\
\text { (wt. } \% / \text { wt. } \%)\end{array}$ & 100:0 & $75: 25$ & $50: 50$ & $25: 75$ & $0: 100$ & \multirow{5}{*}{ [106] } \\
\hline & \multirow{2}{*}{$\begin{array}{l}\text { Batch, } \\
573 \mathrm{~K}, \\
30 \mathrm{~min}\end{array}$} & Yield (wt.\%) & $\begin{array}{c}\text { Bio-oil } \\
\text { Solid residue }\end{array}$ & $\begin{array}{l}29.0 \\
57.0\end{array}$ & $\begin{array}{l}64.0 \\
20.0\end{array}$ & $\begin{array}{l}69.0 \\
16.0\end{array}$ & $\begin{array}{l}23.0 \\
66.0\end{array}$ & $\begin{array}{l}19.0 \\
63.0\end{array}$ & \\
\hline & & $\begin{array}{l}\text { Content in } \\
\text { bio-oil }\end{array}$ & MAC & 12.0 & 8.0 & 10.0 & 27.0 & 36.0 & \\
\hline & \multirow{2}{*}{$\begin{array}{l}\text { Batch, } \\
623 \mathrm{~K}, \\
30 \mathrm{~min}\end{array}$} & Yield (wt.\%) & $\begin{array}{l}\text { Bio-oil } \\
\text { Solid residue }\end{array}$ & $\begin{array}{l}35.0 \\
40.0\end{array}$ & $\begin{array}{l}47.0 \\
19.0\end{array}$ & $\begin{array}{l}23.0 \\
48.0\end{array}$ & $\begin{array}{l}22.0 \\
50.0\end{array}$ & $\begin{array}{l}25.0 \\
53.0\end{array}$ & \\
\hline & & $\begin{array}{l}\text { Content in } \\
\text { bio-oil }\end{array}$ & MAC & 12.0 & 7.0 & 11.0 & 14.0 & 17.5 & \\
\hline
\end{tabular}

Sum of Monomeric Aromatic Chemicals (MAC).

Cheng et al. [109] studied the effect of the initial ethanol concentration for HTL of alkaline lignin in a micro-reactor (batch). The initial ethanol concentration was varied between $0 \mathrm{vol} \%$ and $100 \mathrm{vol} \%$, while the temperature was kept constant at $573 \mathrm{~K}$ for $4 \mathrm{~h}$. With pure water, the yield of degraded lignin (DL) was around $50 \mathrm{wt} . \%$, while the yields of WSO, solid residue (SR) and gas were ca. $9 \mathrm{wt} . \%, 33 \mathrm{wt} . \%$ and $0 \mathrm{wt} . \%$, respectively. When the initial ethanol concentration increased up to $50 \mathrm{vol}-\%$, the authors achieved the highest yield of DL (88 wt.\%), while the yields of WSO, SR and gas were round $2 \mathrm{wt} . \%$, $2 \mathrm{wt.} \%$ and $8 \mathrm{wt} . \%$, respectively. Generally, ethanol under these conditions was found to prevent solid residue formation, limit WSO formation and favor gas production. Lee et al. [106] studied the HTL of Kraft lignin, where ethanol was used as a co-solvent. The initial ratio of water-to-ethanol (wt.\%: wt.\%) varied between 100:0 and 0:100 at temperatures of $573 \mathrm{~K}$ and $623 \mathrm{~K}$ and the residence time was $30 \mathrm{~min}$. At $573 \mathrm{~K}$ and with pure water, the bio-oil yield was around $30 \mathrm{wt} . \%$ and it increased up to ca. $70 \mathrm{wt} . \%$ when the ratio of water to ethanol increased to 50:50. Similarly, the SR yield decreased from $57 \mathrm{wt} . \%$ to $17 \mathrm{wt} . \%$. Higher ratios of water to ethanol led to a higher SR yield, but the bio-oil yield decreased. At the higher temperature of $623 \mathrm{~K}$, the bio-oil yield with pure water was ca. $34 \mathrm{wt} . \%$ and it increased 
to $45 \mathrm{wt} . \%$ as the ratio of water to ethanol increased to $75: 25$, while the char yield reached a minimum of $20 \mathrm{wt} . \%$.

In pure water, the dominant reaction pathway from lignin-derived compounds into other products takes place via decarbonylation and hydrolysis reactions [106]. In this study, it was proposed that ethanol works as a hydrogen donor in hydrogenolysis reactions and it stabilizes the intermediate products generated during the degradation of lignin [106]. First, the degraded lignin products react to alkylated guaiacols via hydrogenation reactions. The alkylated guaiacols further react with phenol and guaiacol via hydrogenolysis reactions in the presence of ethanol. However, in other biomasses that were investigated, using ethanol as a solvent led to a wider spectrum of compounds in the product compared to the tests with pure water [99,134]. Forchheim [99] proved that ethanol reacted with intermediate compounds to produce ethylated phenols, but less catechol in comparison to water as sole solvent. In addition, the degradation of lignin was also found to be slower in ethanol than in water and it was assumed that ethanol decomposes into gaseous compounds, such as ethane, at high reaction temperatures [99].

Melin et al. [124] investigated the impact of glycerol as a hydrogen donor and char-reducing agent in HTL. They observed that the addition of $25 \mathrm{wt} . \%$ glycerol of the content of black liquor dry matter increased the bio-oil carbon yield from $58 \%$ to $64 \%$ for HTL at $623 \mathrm{~K}$ and 45 min residence time. However, addition of $50 \mathrm{wt} . \%$ glycerol of the content of black liquor dry matter decreased the carbon yield to $52 \%$. The highest bio-oil heating value was observed when glycerol was up to $59 \mathrm{wt} . \%$ of the black liquor dry matter. The highest $H H V$ of bio-oil (after washing to remove residual ash) was $39.3 \mathrm{MJ} / \mathrm{kg}$ on a dry basis in a study with a high dry glycerol addition of $59 \mathrm{wt} . \%$ of black liquor dry matter and with the addition of $12 \mathrm{wt} . \% \mathrm{NaOH}$ at $633 \mathrm{~K}$ with a 45 -min reaction time [124].

Another promising co-solvent is phenol, which has been used in several studies related to the HTL of black liquor (see Table 10) [110-112]. Arturi et al. [111] studied the HTL of Indulin ${ }^{\circledR \circledR}$ AT (pine Kraft lignin) in the presence of ca. $1.7 \mathrm{wt} . \% \mathrm{~K}_{2} \mathrm{CO}_{3}$ with various initial phenol concentrations of between 0.0 and $10 \mathrm{wt} . \%$ at $573 \mathrm{~K}$ and with a residence time of $15 \mathrm{~min}$. As the initial phenol content increased from $0 \mathrm{wt} . \%$ to $10 \mathrm{wt} . \%$, the bio-oil yields rose from 34 to $102 \mathrm{wt} . \%$. At the same time, the yields of WSO slightly increased from $0.2 \mathrm{wt} . \%, 3.5 \mathrm{wt} . \%$ while the yield of insoluble compounds decreased from $54 \mathrm{wt} . \%$ to $1.4 \mathrm{wt} . \%$. The fact that the bio-oil yield exceeded $100 \mathrm{wt} . \%$ with the initial phenol concentration of $10 \mathrm{wt} . \%$ is assumed to be caused by the reactions between some of the intermediate products and the phenol. The initial phenol concentration influenced the yields of different chemical compounds present in both the WSO and bio-oil fractions. The yields of non-condensed aromatic dimers (2-NCAD), alkylphenols, methoxybenzenes, guaiacols and anisolic/phenolic dimers (APD) were near to $0.0 \mathrm{wt} . \%$ when the experiment was performed with pure water. Increasing the initial phenol concentration from $0.0 \mathrm{wt} . \%$ to $6.5 \mathrm{wt} . \%$ improved the total yield of monomeric compounds from $0.8 \mathrm{wt} . \%$ to $10.8 \mathrm{wt} . \%$. However, there was no significant change in the elemental composition with different initial phenol concentrations. The higher heating value of the biocrude increased from $29.8 \mathrm{MJ} / \mathrm{kg}$ to $31.2 \mathrm{MJ} / \mathrm{kg}$ as the initial phenol concentration was raised from $0.0 \mathrm{wt} . \%$ to $10 \mathrm{wt} . \%$.

Belkheiri et al. [112] studied the effect of phenol as a capping agent with the HTL of LignoBoost lignin at $623 \mathrm{~K}$ and $25 \mathrm{MPa}$. The initial phenol concentrations varied between $2.0 \mathrm{wt} . \%$ and $10 \mathrm{wt} . \%$ while the initial concentration for $\mathrm{KOH}$ was $0.3 \mathrm{wt} . \%$, and for $\mathrm{K}_{2} \mathrm{CO}_{3}$ it was $1.6 \mathrm{wt} . \%$. The experiments took place in a continuous catalytic reactor where zirconia $\left(\mathrm{ZrO}_{2}\right)$ was used as a heterogeneous catalyst (see below). The yield of bio-oil varied between $58.3 \mathrm{wt} . \%$ and $63.6 \mathrm{wt} . \%$ while the yield of WSO fluctuated between $14.7 \mathrm{wt} . \%$ and $26.6 \mathrm{wt} . \%$ as the phenol concentration was changed from $2.0 \mathrm{wt} . \%$ to $10.0 \mathrm{wt} . \%$. The yield of char staid stable at ca. $60 \mathrm{wt} . \%$ whatever the phenol concentration. Belkheiri et al. [112] concluded that even a low phenol concentration ( $2 \mathrm{wt} . \%$ of initial mass) had a positive effect on the HTL of lignin, and the use of higher phenol concentrations did not have any significant effect on the yields of other fractions. However, there were changes with the yields of different compounds. For example, the yield of alkyl phenols increased from 2.4 to 3.4 when the initial phenol concentration increased from $2.0 \mathrm{wt} . \%$ to $10.0 \mathrm{wt} . \%$. The elemental composition of the produced 
bio-oil fraction did not change significantly as the initial phenol concentrations increased. The weight fractions of $\mathrm{C}, \mathrm{H}$ and $\mathrm{O}$ varied between 73.9-74.3, 6.3-6.9, and 17.9-20.6, respectively. The viscosity of the bio-oil was highest with the two lowest initial phenol concentrations ( $2.0 \mathrm{wt} . \%$ and $4.0 \mathrm{wt} . \%)$, while it decreased significantly when the initial phenol concentrations increased above that.

Table 10. Summary of HTL experiments with phenol as co-solvent.

\begin{tabular}{|c|c|c|c|c|c|c|c|c|c|}
\hline Feedstock & & & & & & & & & Ref \\
\hline \multirow{12}{*}{ Indulin AT } & \multirow[t]{12}{*}{ Reaction condition } & Solvent & Phenol (wt.\%) & 0.00 & 3.40 & 6.50 & 9.70 & & \multirow{12}{*}{ [111] } \\
\hline & & \multirow{4}{*}{$\begin{array}{l}\text { Yield (wt.\%) } \\
\text { (phenol-free } \\
\text { basis) }\end{array}$} & Biocrude & 33.9 & 77.3 & 87.6 & 102.3 & & \\
\hline & & & WSO & 0.2 & 4.4 & 4.9 & 3.5 & & \\
\hline & & & Insolubles & 54.4 & 11.3 & 7.1 & 1.4 & & \\
\hline & & & C-recovery & 86.2 & 102.3 & 82.8 & 95.5 & & \\
\hline & & \multirow{2}{*}{$\begin{array}{l}\text { Total yield } \\
\text { (wt.\%) }\end{array}$} & 1-ring aromatics & 0.8 & 8.0 & 10.8 & 11.5 & & \\
\hline & & & 2-ring aromatics & 0.0 & 1.0 & 1.6 & 9.7 & & \\
\hline & & \multirow{4}{*}{$\begin{array}{l}\text { Elemental } \\
\text { composition } \\
\text { (wt.\%) }\end{array}$} & $\mathrm{C}$ & 69.9 & 67.3 & 72.0 & 72.3 & & \\
\hline & & & $\mathrm{H}$ & 5.7 & 6.1 & 6.4 & 6.2 & & \\
\hline & & & $\mathrm{s}$ & 0.6 & 0.7 & 0.7 & 0.6 & & \\
\hline & & & $\mathrm{O}$ & 23.6 & 25.9 & 21.0 & 20.5 & & \\
\hline & & $\begin{array}{l}\text { Higher heating } \\
\text { value }(\mathrm{MJ} / \mathrm{kg})\end{array}$ & HHV & 29.8 & 30.4 & 31.1 & 31.2 & & \\
\hline \multirow{16}{*}{$\begin{array}{l}\text { Ligno-Boost } \\
\text { Lignin }\end{array}$} & \multirow[t]{6}{*}{ Reaction condition } & Solvent & Phenol (wt.\%) & 2.00 & 3.00 & 4.00 & 5.00 & 10.00 & \multirow{16}{*}{ [112] } \\
\hline & & \multirow{4}{*}{$\begin{array}{l}\text { Yield (wt.\%) } \\
\text { (phenol-free } \\
\text { basis) }\end{array}$} & Bio-oil & 62.7 & 59.3 & 58.4 & 63.6 & 58.3 & \\
\hline & & & WSO & 21.3 & 20.9 & 26.6 & 25.5 & 14.7 & \\
\hline & & & Char & 13.8 & 13.6 & 14.6 & 12.6 & 12.3 & \\
\hline & & & Total gas & 2.0 & 6.0 & 4.0 & 5.0 & 3.0 & \\
\hline & & \multirow{5}{*}{$\begin{array}{l}\text { Total yield } \\
\text { (wt.\%) }\end{array}$} & Catechols & 0.2 & 0.3 & 0.0 & 0.1 & 1.1 & \\
\hline & \multirow{10}{*}{$\begin{array}{l}\text { Continuous, catalytic } \\
\text { Fixed Bed Reactor, } \\
623 \mathrm{~K}, \\
250 \mathrm{bar} \\
15 \mathrm{~min}, \\
\mathrm{~K}_{2} \mathrm{CO}_{3}\end{array}$} & & Anisoles & 5.0 & 6.1 & 5.3 & 4.9 & 7.1 & \\
\hline & & & Alkyl Phenols & 2.4 & 3.4 & 3.2 & 3.3 & 4.6 & \\
\hline & & & Guaiacols & 3.9 & 3.6 & 2.9 & 2.5 & 1.4 & \\
\hline & & & Phenolic dimers & 0.8 & 1.6 & 1.9 & 3.2 & 2.9 & \\
\hline & & \multirow{5}{*}{$\begin{array}{l}\text { Elemental } \\
\text { composition } \\
\text { (wt.\%) }\end{array}$} & $C$ & 73.9 & 72.9 & 74.3 & 72.1 & 77.2 & \\
\hline & & & $\mathrm{H}$ & 6.9 & 6.3 & 6.6 & 6.3 & 6.9 & \\
\hline & & & $\mathrm{s}$ & 0.4 & 0.3 & 0.3 & 0.3 & 0.3 & \\
\hline & & & $\mathrm{O}$ & 17.9 & 9.7 & 18.2 & 20.6 & 14.8 & \\
\hline & & & $\mathrm{Na}$ & 0.3 & 0.2 & 0.1 & 0.2 & 0.1 & \\
\hline & & $\begin{array}{l}\text { Higher heating } \\
\text { value }(\mathrm{MJ} / \mathrm{kg})\end{array}$ & HHV & 32.1 & 30.8 & 31.8 & 30.4 & 33.6 & \\
\hline
\end{tabular}

In another study, Belkheiri et al. [110] investigated the effect of phenol and methanol as co-solvents when treating LignoBoost lignin from softwood in subcritical water [110]. The initial lignin concentration was $5.5 \mathrm{wt} . \%$, while the initial concentrations of methanol and phenol were varied $(0.0-41.0 \mathrm{wt} . \%$ for methanol and 0.0-4.1 wt.\% for phenol). The experiments were carried out in a continuously working pilot plant with homogeneous catalysts $\left(\mathrm{K}_{2} \mathrm{CO}_{3}\right.$, initial concentration of $\left.1.6 \mathrm{wt} . \%\right)$ and heterogeneous catalysts $\left(\mathrm{ZrO}_{2}\right)$ at temperatures between $553 \mathrm{~K}$ and $583 \mathrm{~K}$. The maximum bio-oil yield was $72.2 \mathrm{wt} . \%$ when only phenol (initial concentration of $4.1 \mathrm{wt} . \%$ ) was used at $623 \mathrm{~K}$. Similarly, the yields of WSO and char were $9.7 \mathrm{wt} . \%$ and $20.7 \mathrm{wt} . \%$, respectively. The use of initial concentrations of methanol and phenol of $39 \mathrm{wt} . \%$ and $3.9 \mathrm{wt} . \%$ at $583 \mathrm{~K}$ led to the lowest char yield of $14.1 \mathrm{wt} . \%$. Similarly, the yields of char and WSO were $38.8 \mathrm{wt} . \%$ and $24 \mathrm{wt} . \%$, respectively. The use of only methanol as a co-solvent led to clogging in the reactor.

Water is the main component of black liquor and the use of co-solvents can benefit the HTL of black liquor by preventing some reactions and promoting others. As a result, the use of either aliphatic alcohols or phenol as a co-solvent improves the bio-oil yield when treating black liquor under suband supercritical water conditions. Studies of the addition of aliphatic alcohols to black liquor or model solutions indicate that their optimal initial concentration needs a higher ratio (in the range of $25-50 \mathrm{wt} . \%$ of dry matter) than the initial concentrations of phenol ( $<10 \mathrm{wt} . \%)$, although both were able to improve bio-oil yields at their respective concentrations. In addition, the phenol-stabilized HTL reactions led to lower char yields. The use of methanol as the sole co-solvent can lead to clogging 
problems in an HTL reactor. The lessons learned from the various studies performed on black liquor (or model black liquors) with co-solvents can be summarized as follows:

- Ethanol was found to prevent solid residue formation and limit the conversion of feedstock to WSO.

- Adding glycerol to black liquor can lead to improvement in the bio-oil heating value, the carbon yield, and the fluidity of the bio crude, but these benefits are limited.

- The addition of phenol to the HTL of lignin with $\mathrm{K}_{2} \mathrm{CO}_{3}$ or $\mathrm{K}_{2} \mathrm{CO}_{3}+\mathrm{KOH}$ improves bio-oil yields and the yields of dimers and monomers, while it tends to reduce the yield of insoluble compounds (dry solids).

- Phenol as a co-solvent gives better results than aliphatic alcohols, probably due to its better reactivity with the reaction intermediates that are subject to repolymerization

\section{Reaction Chemistry}

The degradation of black liquor is a complex process, involving a large variety of reactions, intermediate products and final products. In addition to the process parameters, the composition of black liquor varies from one plant to another, and even from one season to another.

\subsection{Reaction Pathways and Kinetics}

Although lignin degradation under sub- and supercritical conditions has been studied in recent years, the degradation of black liquor lignin has received very little attention. A few studies have proposed reaction pathways for lignin degradation under sub- and supercritical water conditions [97-100], but the lignin used in these studies was not derived from black liquor. Nevertheless, the results of these experiments may be a useful guide to understanding the degradation of lignin contained in black liquor.

Generally, the models in such studies use lumped compounds, where several intermediate and final products are modeled as one compound. In addition, some of the studies have focused on the degradation of model lignin compounds or on the splitting of the bonds that are found between lignin monomers [135-139]. The most relevant of all these studies is one on the degradation of Indulin AT in water [140] as Indulin AT is derived from the black liquor of soft wood. Schuler recently developed a reaction model for the degradation of Indulin AT (Kraft lignin) under subcritical water conditions [140]. His model expands on Forchheim's model [100], which also studied the degradation of lignin from ethanol production under subcritical water conditions [140]. The advantage of Indulin AT is that it is mostly built from one monomeric unit, coniferyl alcohol, which seems to be a direct precursor of the formed monocycles. With short residence times, the phenol concentration increases, along with the guaiacol and catechol contents. This indicates that phenol splits straight out of coniferyl alcohol. With longer residence times the concentration of phenol plateaus, which indicates passive products and that there are hardly any subsequent reactions. O-cresol and p-cresol are minor consecutive products derived from phenol [140]. 4-ethylcatechol shows similar concentration profiles as 4-methylcatechol, and this leads to the conclusion that they are both sequential products of catechol, while catechol, 4-ethylguaiacol and 4-methylguaiacol seem to be products of the reactions of guaiacol with the methyl and ethyl components. Based on these assumptions, an extended reaction network was drawn, shown in Figure 13.

The model was built starting from one consecutive reaction:

$$
\begin{aligned}
& \text { Coniferyl alcohol } \rightarrow \text { guaiacol }+ \text { different side products } \\
& \qquad \mathrm{C}_{10} \mathrm{H}_{12} \mathrm{O}_{3} \rightarrow \mathrm{C}_{7} \mathrm{H}_{8} \mathrm{O}_{2}+\mathrm{C}_{\mathrm{n}} \mathrm{H}_{\mathrm{m}} \mathrm{O}_{\mathrm{p}} \\
& \text { guaiacol } \rightarrow \text { catechol }(\rightarrow 4-\text { methylcatechol }) \\
& \mathrm{C}_{7} \mathrm{H}_{8} \mathrm{O}_{3}+2 \mathrm{H}^{+} \rightarrow \mathrm{C}_{6} \mathrm{H}_{6} \mathrm{O}_{2}+\mathrm{CH}_{4} \\
& \left(\mathrm{H}_{2} \mathrm{O} \leftrightarrow \mathrm{H}^{+}+\mathrm{OH}^{-}\right)
\end{aligned}
$$




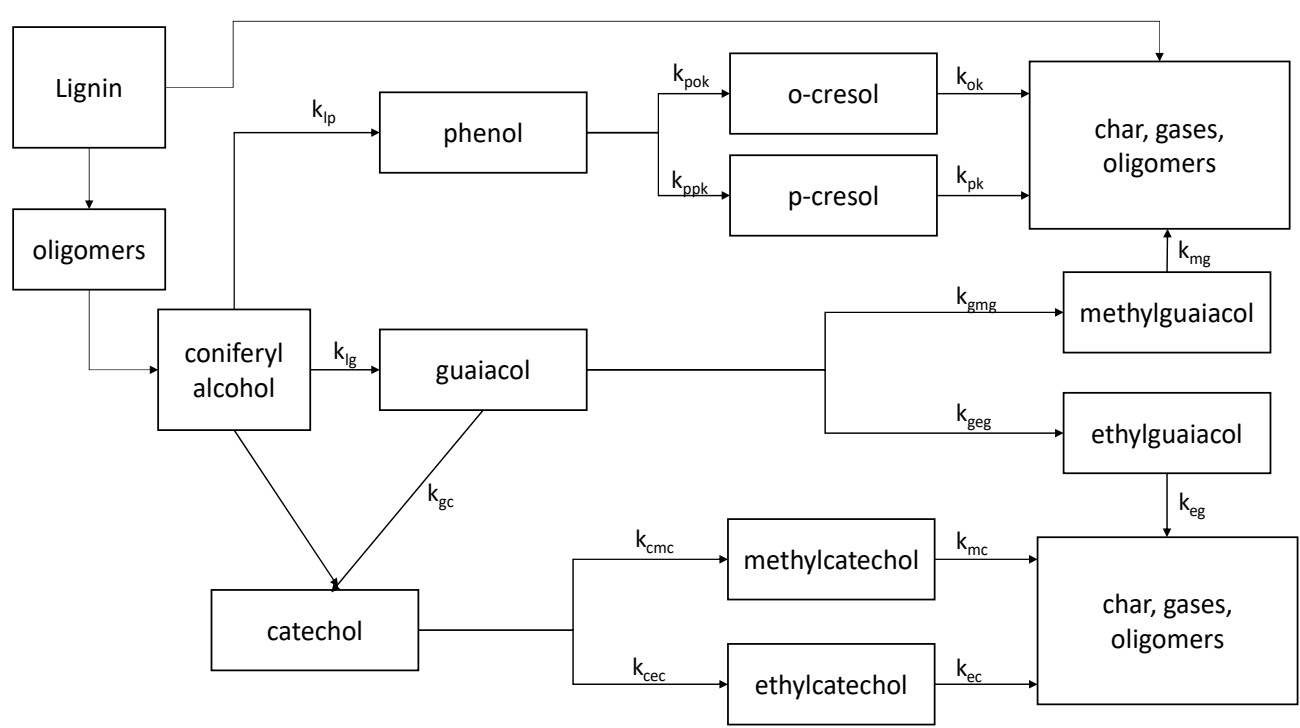

Figure 13. Reaction pathway for the degradation of Indulin AT. Figure is adapted from Schuler [140].

For the reactions, first-order kinetics were assumed, with the assumption of a reaction under constant volume. Under this assumption and because Indulin At is mainly composed of coniferyl monomers (see [140]), the starting concentration of coniferyl alcohol can be calculated backwards from the determined concentration profiles for different temperatures and their resulting pressures, residence times and the presence of $0.1 \mathrm{wt} . \% \mathrm{KOH}$. It is possible, under the assumption of no mass transport limitations, to quantitatively describe the temperature dependence and the reaction rate via the Arrhenius equation for different temperatures.

To provide a better correlation, the Arrhenius parameters for a low temperature regime from $548 \mathrm{~K}$ to $573 \mathrm{~K}$ and a high temperature regime from $586 \mathrm{~K}$ to $623 \mathrm{~K}$ were calculated and explained by the change of water's properties with temperature, and the consequent changes in the reaction mechanism [140] (also observed in [129]). The model was extended for other biomass sources as well, and can be used now to predict the monomeric product spectra of lignin under hydrothermal liquefaction conditions [140]. However, the suitability of this reaction pathway and kinetics for modeling the degradation of lignin from black liquor is unclear and needs further study. In addition, a reaction model that can be used to model reactions under supercritical water conditions, and in the presence of various cooking chemicals, needs to be developed. Please note that the presence of inorganic salts and the many other organic compounds (e.g., hydroxycarboxylates) from cellulose and hemicellulose decomposition may strongly affect the kinetics and reaction mechanisms. Thus, the reaction pathway and kinetics need to be modified in order to model the HTL of the black liquor-lignin degradation process accurately.

\subsection{Sulfur Chemistry in Supercritical Water}

Sulfur is present in various concentrations and chemical forms, which is an issue for many applications and downstream hydrothermal treatments for several economic, health and environmental reasons. Depending on the raw material and the process conditions, the composition of sulfur species present in black liquor varies and is divided into inorganic salts (see Table 3) and organic species.

\subsubsection{Organosulfur Compounds}

Any organosulfur species present in black liquor will be subject to various and complex reactions with other organic compounds when exposed to (near) supercritical water. Studies performed on the HTL of black liquor found that the amount of sulfur in the biocrude was significantly lower (4 to 10 times) than it was in the initial Kraft lignin [58,107,112,115]. However, no studies have yet been 
performed to identify the organosulfur compounds in the biocrude produced in these studies. Most studies of the chemistry and stability of organosulfur compounds in supercritical water are linked to the desulfurization of crude oil, [141-143], and thus most of these studies assume conditions that are seldom found in the HTL of black liquor. It appears from existing studies that both ionic reactions, prevailing in the subcritical region, and free radical reactions favored in supercritical water may be competing in the decomposition of organosulfur compounds [144].

Alkylthiols, thioaldehydes and thioketones are among the organosulfur compounds most likely to be present in black liquor, or to be formed in the early stages of Kraft lignin decomposition [145]. According to Katritzky et al. [146], thioaldehydes and thioketones are readily hydrolyzed at the relatively low temperature of $250{ }^{\circ} \mathrm{C}$, leading to the formation of hydrogen sulfide. Alkylthiols were also found to decompose readily under near-critical water conditions following both ionic elimination reactions and free radical reactions [146-148]. Specifically, 1-decanethiol has been shown to decompose at a temperature as low as $250^{\circ} \mathrm{C}$, mostly into hydrogen sulfide and 1-decene or nonane through either ionic or radical reactions, respectively $[146,148]$. The formation of alkyl-tetrahydrothiophene and alkyl sulfide through radical reactions, or various isomeric thiols through the Willgerodt reaction, have been observed. Overall, thiol decomposition is believed to be favored by an ionic contribution of water, as evidenced by the large difference in a product's composition after decomposition in either water or cyclohexane [146,148].

Organic sulfides and disulfides generally have a (somewhat) higher decomposition rate than thiols [146]. The dominating reactions identified were homolytic cleaving of C-S bonds and further reactions of the generated radicals. The decomposition of aliphatic, aromatic, and cyclic sulfides into $\mathrm{H}_{2} \mathrm{~S}$ is highly dependent on the strength of the C-S bonds, and on the presence and enthalpies of the reaction of $\alpha$-hydrogens. Their reactivity trend can be expressed in the following order: alkyl sulfides $\approx$ aromatic sulfides $>>$ thiophenic compounds $[144,148,149]$. Free radical reactions are typically used to describe the formation of alkyl polysulfides [146-148], alkyl-tetrahydrothiophene [146,147], 1-alkene and alkyl thiol from n-alkyl sulfides through radical elimination reactions [146] or (n-1)-alkanes [146,150,151]. In a recent study combining both experimental work and theoretical calculations, the free radical mechanism of the decomposition of $n$-alkyl sulfide in supercritical water has been further investigated [151]. The identified mechanism involves the cleavage of a C-S bond to form a thioaldehyde, which is a key intermediate known for its reactivity under SCW [146]. Its formation through a cascade of radical reactions and the abstraction of the $\alpha$-hydrogen has been identified as the rate-determining step, which explains the difference in reactivity between aliphatic and aromatic sulfides [148]. The reaction of a $\mathrm{C}=\mathrm{S}$ bond with water, most likely via pericyclic addition, and the formation of an intermediate geminal mercaptoalcohol leads to the formation of $\mathrm{H}_{2} \mathrm{~S}$ and an aldehyde, the latter decomposing to $\mathrm{CO}$ and (n-1)-alkyl. All the sulfur-containing aromatic molecules typically found in petroleum, such as diphenylsulfide, naphthyl phenyl sulfides or benzothiophenes, are rather stable under hydrothermal conditions, with or without additives [150]. For instance, diphenylsulfide showed 0 and $9 \%$ conversion after $60 \mathrm{~min}$ at $460{ }^{\circ} \mathrm{C}$ in pure water and $15 \mathrm{wt} . \% \mathrm{Na}_{2} \mathrm{CO}_{3}$ water solution, while benzo[b]thiophene showed 0 and $1.6 \%$ conversion after $60 \mathrm{~min}$ at $460^{\circ} \mathrm{C}$ in pure water and $15 \mathrm{wt} . \% \mathrm{HCO}_{2} \mathrm{Na}$ water solution.

Most of the studies described above were performed with model organosulfur compounds in supercritical water media. The presence of organic compounds (alkanes, aryls, etc.) and inorganic salts can, however, have an important impact on the reaction rates and mechanisms. Compounds with weak $\mathrm{C}-\mathrm{S}$ and $\mathrm{S}-\mathrm{S}$ bonds are thought to play a central role in petroleum rate formation through the initiation of radical free reactions [152], and this influence is expected to operate in both directions. Indeed, experiments on the hydrothermal decomposition of model benzothiophene and dibenzothiophene showed that they decompose well under near-critical and supercritical conditions in the presence of $\mathrm{NaOH}$ and $\mathrm{KOH}$, while these molecules were shown to be stable during the treatment of bitumen even at long residence times [143]. This decrease in decomposition rates was also observed in the absence of alkaline salts and with model hydrocarbons [148]. This decrease of sulfide decomposition in the presence of hydrocarbons can be explained by the relative stability of the hydrocarbon radicals produced. 
With the addition of phosphate to supercritical water $(\mathrm{pH} 10.5), 15 \%$ sodium formate or carbonate seems to partially decrease the decomposition rate of the alkylthiols [146] and thiophenol [150]. In the presence of a base, thiophenol was observed to decompose to diphenylsulfide which then slowly decomposed into benzene. In an aqueous sodium bisulfite mixture at $250{ }^{\circ} \mathrm{C}$, thiophenol can be readily converted into diphenyl sulfide, disulfide and trisulfide, as well as thianthrene [153]. More generally, sodium bisulfite increases the rate of conversion of arenethiols by a factor of 5 , mainly through oxidative coupling reactions that lead to stable diaryl sulfides and sulfur heterocycles. However, aryl alkyl sulfides were found to readily decompose under these conditions because of the carbon-sulfur bond's tendency to split.

All these studies indicate that for a complex black liquor mixture, a significant proportion of the organosulfur compounds (thiolate, thioaldehydes) will decompose into inorganic sulfides. However, the presence of inorganic sulfur salts, such as sulfide and sulfite, and other organic compounds, should favor the stability of the organic sulfides and the formation of hydrothermally stable thiophenic compounds.

\subsubsection{Inorganic Species}

In the field of geochemistry, it is well known that sulfates and sulfites can be reduced to sulfides in hydrothermal conditions in the presence of organic molecules [154-158]. Consequently, thermochemical sulfate reduction (TSR) has usually been studied for its importance in the formation of sulfide ores [159]. These studies indicate that sulfide itself significantly promotes sulfate reduction, and while the mechanism remains unclear, it is thought to occur through its reaction with organic molecules leading to labile sulfur (organic) compounds (LSC) (e.g., thiols, sulfides, polysulfides, etc.) $[155,160,161]$. These organosulfur compounds have been shown to catalyze TSR at significantly better rates than $\mathrm{H}_{2} \mathrm{~S}$ through a mechanism that remains unclear, but is, however, likely to involve the generation of $S$ radicals from the LSCs or the direct reaction of thiol with sulfate to form a sulfate ester [155,162]. In addition, partially oxidized organic compounds (alcohols, ketones, acids) are also key for the rate of sulfur reduction, specifically with reduced sulfur species, which can be linked to their better reactivity with sulfides [160]. Finally, experimental [161] and DFT [163] studies have pointed to the significant effect that the sulfate cation can have on the stability of sulfate and its reduction. At a $\mathrm{pH}$ above 7 , $\mathrm{MgSO}_{4}$ salt is regarded as the reactive form of the sulfate in natural oil reservoirs. However, these studies did not compare the effect of various cations on the thermochemical reduction of sulfate.

It is important to note that any elemental sulfur that might form during the hydrothermal treatment of black liquor is not stable under supercritical water conditions. Above $150-200{ }^{\circ} \mathrm{C}$, it will react with the water to form hydrogen sulfide and sulfuric acid or thiosulfate through the formation of radicals $[164,165]$. In the model developed by Yakaboylu et al. in a reductive environment, thermodynamically favored species between $300^{\circ} \mathrm{C}$ and critical point are a mix of $\mathrm{H}_{2} \mathrm{~S}, \mathrm{HS}^{-}$and $\mathrm{S}^{2-}$, while beyond that point gaseous $\mathrm{H}_{2} \mathrm{~S}$ is dominating [166].

\subsection{Bio-Oil Quality}

The quality of the produced bio-oil is an important factor, because it has an influence on its upgradability. Table 11 shows the most important properties of bio-oils produced from the HTL of black liquor or lignin-related black liquor, including the main compounds present in the oil and the elemental composition of the product. 
Table 11. The quality of produced bio-oils.

\begin{tabular}{|c|c|c|c|c|c|c|c|c|c|c|c|}
\hline Feed & Process Type & $\begin{array}{c}\mathrm{C} \\
\text { wt. } \%\end{array}$ & $\begin{array}{c}\text { H } \\
\text { wt. } \%\end{array}$ & $\begin{array}{c}\mathrm{O}^{\mathrm{A}} \\
\text { wt.\% }\end{array}$ & $\begin{array}{c}\mathrm{S} \\
\text { wt. } \%\end{array}$ & $\begin{array}{c}\mathrm{Na} \\
\text { wt.\% }\end{array}$ & $\begin{array}{c}\mathrm{K} \\
\text { wt. } \%\end{array}$ & $\begin{array}{c}H H V \\
\mathrm{MJ} / \mathrm{kg}\end{array}$ & $\begin{array}{c}M_{w} \\
\mathrm{~g} / \mathrm{mol}\end{array}$ & $\begin{array}{c}M_{n} \\
\mathrm{~g} / \mathrm{mol}\end{array}$ & Ref \\
\hline Kraft lignin & Batch & & & $11.0-22.0$ & 0.53 & & & $28.3-34.7$ & $500-1160$ & $200-450$ & {$[106]$} \\
\hline Ligno-Boost lignin & CSTR & $70.0-76.0$ & $6.1-6.8$ & $15.0-21.0$ & $0.25-0.56$ & $<0.01-0.011$ & $1.7-1.4$ & $31.03-32.73$ & & & [107] \\
\hline Black liquor & Batch & 80.7 & 8.6 & 10.45 & 0.45 & $<0.01$ & $<0.01$ & & 550 & & [58] \\
\hline Alkaline lignin & Batch & & & & & & & & $530-1453$ & $260-566$ & [109] \\
\hline Ligno-Boost lignin & $\begin{array}{l}\text { Continuous, catalytic } \\
\text { Fixed Bed Reactor }\end{array}$ & & & & & & & & & & [110] \\
\hline Ligno-Boost lignin & $\begin{array}{l}\text { Continuous, catalytic } \\
\text { Fixed Bed Reactor }\end{array}$ & $70.0-76.0$ & $6.1-6.8$ & $15.0-21.0$ & $0.25-0.56$ & $<0.01-0.011$ & $1.7-1.4$ & $31.03-32.73$ & & & [107] \\
\hline Alkaline lignin & Batch & & & & & & & & & & [95] \\
\hline Indulin AT & CSTR & $67.3-72.4$ & $5.5-6.5$ & $20.5-25.9$ & $0.41-0.72$ & & & 29.8-32.1 (dry) & & & [111] \\
\hline Ligno-Boost lignin & $\begin{array}{l}\text { Continuous, catalytic } \\
\text { Fixed Bed Reactor }\end{array}$ & $72.1-74.3$ & $6.3-6.9$ & $14.8-20.6$ & $0.3-0.4$ & $0.1-0.3$ & $0.5-0.7$ & $30.4-33.6$ & & & [112] \\
\hline Ligno-Boost lignin & $\begin{array}{l}\text { Continuous, catalytic } \\
\text { Fixed Bed Reactor }\end{array}$ & $72.4-74.3$ & $6.0-6.6$ & $18.3-20.3$ & $0.3-0.4$ & $0.1-1.0$ & $0.03-0.5$ & $30.0-31.2$ & & & [113] \\
\hline Ligno-Boost lignin & $\begin{array}{l}\text { Continuous, catalytic } \\
\text { Fixed Bed Reactor }\end{array}$ & $74.2-74.9$ & $6.5-6.9$ & $15-17$ & $0.29-0.38$ & $<0.01$ & $0.46-1.90$ & $31.83-31.93$ & & & {$[114]$} \\
\hline Ligno-Boost lignin & $\begin{array}{l}\text { Continuous, catalytic } \\
\text { Fixed Bed Reactor }\end{array}$ & $74.0-75.8$ & $5.7-6.8$ & $13.8-17.3$ & $0.2-0.4$ & $<0.01-0.02$ & & & & & [115] \\
\hline
\end{tabular}


The most abundant chemical compounds in the produced bio-oils are 1-ring aromatic compounds, such as phenols, catechols, anisoles and guaiacols. However, the bio-oils also contain compounds with two or more aromatic rings, such as phenolic dimers, xanthene and retene. In addition to these compounds, there exists numerous other chemical compounds [167]. Identifying all these compounds requires multiple different analysis technologies and separation methods; therefore, only a small number of the components are generally analyzed [167]. Bio-oils are usually unstable when stored for long periods, which further complicates the analysis of the various components present in bio-oi [167]. The weight fractions of $\mathrm{C}, \mathrm{H}, \mathrm{O}$ and $\mathrm{S}$ are between $65.95-80.9 \%, 5.5-8.6 \%, 10.45-25.9 \%$ and $0.2-0.56 \%$, respectively. Typical fossil petroleum contains higher weight fractions of carbon (82-87 wt.\%,) and hydrogen (11-15 wt.\%), and much smaller amounts of oxygen (1-2 wt.\%) and sulfur (<0.5-2 wt.\%) when compared with bio-oils produced in the HTL process $[168,169]$. The $H H V$ of bio-oil varied between $28.3 \mathrm{MJ} / \mathrm{kg}$ and $33.6 \mathrm{MJ} / \mathrm{kg}$, whereas the typical value for fossil crude oil varies between 42 and $47 \mathrm{MJ} / \mathrm{kg}$. Please note that in most studies, the determination of $H H V$ is based on a correlation of the weight fractions of $\mathrm{C}, \mathrm{H}, \mathrm{O}$ and $\mathrm{S}$. The number averaged molar mass $\left(M_{n}\right)$ varied between $200-566 \mathrm{~g} / \mathrm{mol}$ while the mass averaged molar mass $\left(M_{w}\right)$ was between $500-1456 \mathrm{~g} / \mathrm{mol}$. The high variety of $M_{w}$ and $M_{n}$ are due to different reaction condition and additives (solvents and catalysts). Orebom et al. [58] reported that the $M_{w}$ of feedstock (Kraft lignin in black liquor) was $3000 \mathrm{~g} / \mathrm{mol}$ and the corresponding value of the bio-oil produced was ca. $550 \mathrm{~g} / \mathrm{mol}$. This indicates that the chemical compounds of lignin have degraded into significantly smaller compounds.

\section{Review of Techno-Economic Analyses of the Hydrothermal Liquefaction of Black Liquor}

Ultimately, it is the profitability of black liquor HTL that will determine whether it is feasible to implement the process on an industrial scale. Several techno-economic assessments (TEA) have been made for industrial-scale applications. An essential aspect of the economic viability of the black liquor HTL process is how well it is integrated with the pulp mill processes. The main aims of such integration are, for example, heat integration and chemical recovery of the cooking chemicals [170].

The corrosiveness of black liquor and supercritical water impacts on the choice of materials for the process equipment and pipes, and this can have a significant effect on costs. The price of a particular alloy, if required, can be several times higher than that of the metal used for basic pressure parts. Furthermore, machining specialized materials is also more expensive. Thus, selecting suitable materials for the process equipment is highly important. The lack of any comprehensive research on this issue reveals a significant shortcoming.

Funkenbusch et al. [170] conducted a TEA on a process that included the conversion of either black liquor or Kraft lignin to either biofuels or chemicals using HTL processes. The process included an HTL reactor, separation into different phases, a hydrotreatment reactor (HDT), phenolics extraction, distillation and a hydrodeoxygenation (HDO) reactor. It was assumed that the HTL reactor worked under near-critical conditions, and alkali salts were used as a homogenous catalyst. The produced bio-oil was treated as a renewable fuel in the hydrotreatment reactor, while the water-soluble phenolics were extracted by standard LLE (Liquid-Liquid Extraction) equipment from the water phase and then converted into benzene, toluene, ethylbenzene and xylenes (BTEX) in the hydrodeoxygenation reactor. The authors also assumed that the rest of the monomers in the water phase were recycled back into the HTL process to reduce char formation and simultaneously improve the quality of the bio-oil. The alkali cooking chemicals were fed back to the recovery boiler in the solids separated from the centrifuge, and there was also heat integration between the HTL process and the pulp mill process. They studied three different scenarios. The first scenario used existing technology while the second scenario used the best results achieved with laboratory experiments. In the last scenario, they factored in further likely improvements in the technology of the future. The net production cost of biofuel varied between $0.41 \$ /$ liter and $0.44 \$$ /liter, taking into account the BTEX yield that would be obtained from the phenolic compounds in the aqueous phase. The lowest cost of biofuel was achieved with the first scenario, while the highest cost was incurred in the last scenario. The minimum selling price 
(MSP) of the biofuel was between 0.93 \$/liter (3.52 \$/gallon) and $1.02 \$ /$ liter (3.86 \$/gallon), assuming the selling price of the BTEX is $1 \$$ /liter. If the price of biofuel is assumed the same as the sale price of diesel (2.88 \$/gallon) in U.S., then the MSP of the BTEX had to be between 1.65 \$/liter and $2.00 \$ /$ liter.

Ong et al. [171] studied the feasibility of HTL where black liquor together with Radiata pine made up the feedstock for the process. The process included biomass preparation, the HTL process, hydrogen production, upgrading the bio-oil and wastewater processing, and it was also integrated with a pulp mill process. The yields of different compounds of the HTL reactor are based on data obtained from Rowlands et al. [16]. The hydrogen needed in the upgrading unit is produced from off-gases from both the HTL reactor and the natural gas feed. Any alkali salts (the cooking chemicals) are disposed of in the wastewater treatment. The wastewater treatments are included in the cost estimation. The alkali salts are not recovered for the chemical pulp process due to the low concentration of sodium salts in the aqueous fraction. However, the black liquor cost included the cost of replacing the lost salts, and the wastewater treatment costs. Most of the annualized costs come from the installation costs of both the HTL reactor and the upgrading unit, and the operating costs, which accounted for $33 \%, 21 \%$ and $24 \%$, respectively. The MSP of this biofuel was $1.05 \$ /$ liter, corresponding to $0.95 \$$ per liter gasoline equivalent (LGE), which is close to the previous model that included BTEX side production.

The MSP of biofuel must be competitive with the price of fossil fuels to make the HTL process feasible. Between 2014 and 2018 [172], the annual average price of Brent crude fluctuated between $43.6 \$ /$ barrel and $99.0 \$ /$ barrel (ca. $0.36 \$ /$ liter and $0.83 \$ /$ liter). The average price of Brent crude from 2005-2014 was actually at the higher end of that range. More recently, in April 2019 the average price of Brent crude was $71.23 \$ /$ barrel, i.e., ca. $0.61 \$ /$ liter [172]. Table 12 shows the MSP of biofuels from various lignocellulosic residues whose values vary from 0.82 \$/LGE to 2.38 \$/LGE. The difference of the MSP of the fuels arises either from the different ratios of the feeds [173] or variations in the technology used to produce the hydrogen needed in the HDO reactor, and in the efficient use of various by-products [174]. No matter how one looks at it, the MSPs of the biofuels are still higher than the cost of the fossil-based Brent crude oil. In order for the HTL process to become profitable, it is necessary to improve its efficiency and reduce the cost of capital investment for any HTL plant. It does seem safe to assume that the price of fossil fuels will rise in the future, so the process may well become more profitable in the long term.

Table 12. MSP of biofuels produced with different biomass inputs. The last four values are for comparison. The table is edited and updated from Ong et al. [171].

\begin{tabular}{|c|c|c|c|c|c|c|}
\hline Feedstock & $\begin{array}{l}\text { Conver-Sion } \\
\text { Technology }\end{array}$ & Upgra-Ding & Integration & $\begin{array}{l}\text { MSP of the } \\
\text { Fuel (\$/liter) }\end{array}$ & $\begin{array}{l}\text { MSP of the Fuel } \\
\text { (\$/LGE) }\end{array}$ & Ref \\
\hline $\begin{array}{l}\text { Black liquor + } \\
\text { Kraft lignin }\end{array}$ & HTL & HDT & $\begin{array}{l}\text { Integrated with } \\
\text { a pulp mill }\end{array}$ & $0.93-1.02$ & & [170] \\
\hline $\begin{array}{l}\text { Black liquor + } \\
\text { Radiata pine }\end{array}$ & HTL & HDT & $\begin{array}{l}\text { Integrated with } \\
\text { a pulp mill }\end{array}$ & 1.05 & 0.95 & [171] \\
\hline $\begin{array}{l}\text { Wood and } \\
\text { glycerol }\end{array}$ & HTL & HDT & Stand-alone & & $0.82-1.14$ & [173] \\
\hline Forest residue & HTL & HDT & Stand-alone & & 2.00 & [175] \\
\hline Forest residue & Pyrolysis & HDT & Stand-alone & & 3.09 & [175] \\
\hline $\begin{array}{l}\text { Lignocellulosic } \\
\text { forest residue }\end{array}$ & HTL & HDO & Stand-alone & & $0.85-2.38^{\mathrm{A}}$ & [174] \\
\hline
\end{tabular}

A Values are calculated using the average euro-dollar ratio of 2017.

\section{Conclusions}

The HTL process is a promising way to efficiently convert black liquor and its derived compounds into a product called bio-oil, or biocrude. However, the process conditions, residence time and any additives (solvents, catalysts) must be adjusted to optimize the quantity and quality of the bio-oil production and to minimize the formation of unwanted products such as char and gaseous compounds. Black liquor, by its very nature, contains large quantities of alkali salts. Because of their low solubility in hydrothermal conditions, and the risk of corrosion, they can cause a lot of problems for the processing 
equipment by fouling up the pipes and vessels. Some of the salts naturally present in BL are known for their catalytic properties (e.g., $\mathrm{M}_{2} \mathrm{CO}_{3}, \mathrm{MOH}, \mathrm{M}=\mathrm{Na}, \mathrm{K}$ ). These can be used to improve the degradation of the organic compounds present in black liquor, and the proportions of bio-oil, char and gas that are produced. In summary, the following conclusions can be drawn:

- In the case of black liquor, an increase in temperature favors both repolymerization and gasification reactions, leading to a lower yield of bio-oil. The highest yield of bio-oil of in a continuously operated plant was received under subcritical conditions at around $573 \mathrm{~K}$ and residence time of around $12 \mathrm{~min}$. In a batch test conducted slightly above the critical point of water, a bio-oil yield of $70 \mathrm{wt} . \%$ was achieved. There is no data from experiments on black liquor under supercritical water conditions in continuous working reactors, so this should be investigated in the future. The density of supercritical water was found to have an effect on the reaction mechanism, and thus on the products. Therefore, the effect of water density should be investigated to maximize the yield of the desired components.

- In HTL processing, the residence time greatly influences the yields of different fractions and the distribution of the chemical compounds within these fractions. When black liquor-derived lignin is treated under near- and supercritical water conditions, relatively short residence times are recommended in order to limit the amount of unwanted products (char, WSO, gaseous compounds). The longer residence time on batch tests seems to improve the quality of the bio-oil, but on the other hand increases the repolymerization, thus use of higher reaction conditions, and shorter residence time might be feasible. Slightly above supercritical conditions, residence time of few minutes may be enough for sufficient conversion degree.

- Co-solvents can stabilize and improve reactions in the HTL of lignin leading to higher bio-oil yields while inhibiting the formation of residual solids. Phenol appeared to be a more promising co-solvent, as even at low concentrations its use led to a better yield of bio-oil. One reason for the better yield was that phenol stabilizes the intermediate products reducing repolymerization to high molecular weight chemical compounds, i.e., char.

- Existing studies have included experiments where either homogeneous or heterogeneous catalysts were used in the HTL of black liquor-derived lignin. The homogeneous catalyst studies focused on the salts that are naturally present in black liquor, i.e., $\mathrm{K}_{2} \mathrm{CO}_{3}, \mathrm{KOH}, \mathrm{Na}_{2} \mathrm{CO}_{3}$ and $\mathrm{NaOH}$. A similar bio-oil yields were obtained when only one of the cations (either $\mathrm{Na}^{+}$or $\mathrm{K}^{+}$) was present. However, when only $\mathrm{Na}+$ cations were present, the amount of suspended solids (SS) in the bio-oil fraction was significantly lower while the amount of heavy oil was higher. The use of $\mathrm{ZrO}_{2}$ as a heterogeneous catalyst decreased the average molecular weight of the bio-oil.

- The initial lignin concentration in the black liquor can also influence the formation of bio-oil and char. The highest yield of bio-oil yield was achieved when the initial lignin concentration was $5 \mathrm{wt} . \%$. Increasing the concentration of the initial lignin led to higher yield of char and lower yield of bio-oil.

- The large concentration of salts present in black liquor are likely to be precipitated from the mainstream when the water density is low, i.e., in the higher ranges of pressure and temperature typically used for HTL, and this may result in reactor fouling. Under these conditions, the decrease in the solubility of the salts that are homogeneous catalysts for organics liquefaction can significantly impact on their catalytic activity.

- The bio-oil produced from black liquor in the HTL process is significantly different from fossil crude oil. For example, the compounds present in the bio-oil are more oxygenated (oxygen content between $10.5 \mathrm{wt} . \%$ and $25.9 \mathrm{wt} . \%$ ), while typical fossil petroleum contains only $1-2 \mathrm{wt} . \%$ of oxygen. In addition, bio-oil produced from black liquor may contain some impurities, such as alkali salts, that must be removed before it is suitable for conventional refining processes. To use bio-oil as a feedstock for an oil refinery, the amount of impurities and oxygen in the bio-oil should be reduced to acceptable limits. 
- The degradation of lignin in the HTL process is highly complicated and involves a wide range of chemical compounds and reactions. Currently, there is no chemical reaction pathway and kinetic model for the degradation of lignin. However, a model for the degradation of Indulin AT (Kraft Lignin) has been developed, which includes reaction pathways and kinetics for the degradation of lignin under a subcritical water condition. The suitability of the reaction model and kinetics for modeling the degradation of lignin in black liquor must be studied and, presumably, modified. In addition, a reaction pathway and the kinetics of the degradation of black liquor lignin under supercritical water conditions must be developed.

- The profitability of black liquor HTL has been studied in a few TEAs where black liquor is either the main feed or the co-feed to the HTL process. These TEAs have shown that the MSP of biofuel is somewhere between $0.93 \$$ /liter and $1.05 \$$ /liter, while the annual average price of Brent crude oil has fluctuated between $0.36 \$ /$ liter and $0.83 \$ /$ liter over the last 5 years. Therefore, either the price of fossil crude oil must rise, or the MSP of biofuel must decrease before it will be feasible to apply the process on an industrial scale.

Until now, most of the studies of HTL have concentrated on the effects of different process variables and the quality of the bio-oil. However, comparing the research findings of these studies is very challenging because of the different feedstocks used, the different experimental methodologies, and differences in the way the results were analyzed and presented. In addition, there has been woefully little research into the mechanisms and kinetics of the reactions of pure black liquor. Thus, a comprehensive study with comparable results needs to focus on the following issues:

- Increase understanding of continuous operating HTL process applying short residence time (several minutes) under near- and supercritical conditions.

- The effect of inorganic compounds on the reaction mechanisms and kinetics for the degradation of organic compounds of black liquor in near- and supercritical water.

- The solubility and catalytic behavior of alkali salt mixtures (applied in pulping) in near-critical and supercritical water.

- A detailed study of the qualities and costs of corrosion-resistant materials to improve the quality of any future economic evaluations.

Author Contributions: Conceptualization, J.L., D.B., U.H., S.B., J.S., K.M., F.V. J.K. and T.J.; methodology, J.L., and B.D.; formal analysis, J.L., D.B., J.S. and K.M.; investigation, J.L., D.B., J.S. and K.M.; resources, J.L., D.B., J.S. and K.M.; data curation, J.L. and D.B.; writing-original draft preparation, J.L., D.B, J.S. and K.M.; writing-review and editing, J.L., D.B., U.H., S.B., J.S., K.M., F.V. J.K. and T.J.; visualization, J.L., D.B. and J.S.; supervision, J.K.; project administration, T.J.; funding acquisition, J.L., D.B., U.H., S.B., K.M., F.V. J.K. and T.J. All authors have read and agreed to the published version of the manuscript.

Funding: This research was partly funded by Fortum foundation. In addition, this research has also received funding from the European Union's Horizon 2020 research and innovation programme under grant agreement No 884111. This work was supported by the Swiss Innovation Agency Innosuisse and is part of the Swiss Competence Center for Energy Research SCCER BIOSWEET.

Conflicts of Interest: The authors declare no conflict of interest.

\section{References}

1. Masson-Delmotte, V.; Zhai, P.; Pörtner, H.-O.; Roberts, D.; Skea, J.; Shukla, P.R.; Pirani, A.; Moufouma-Okia, W.; Péan, C.; Pidcock, R.; et al. Global Warming of $1.5^{\circ} \mathrm{C}$. 2018. Available online: https:/www.ipcc.ch/site/assets/ uploads/sites/2/2019/06/SR15_Full_Report_High_Res.pdf (accessed on 19 June 2020).

2. International Energy Agency Tracking Clean Energy Progress 2017; International Energy Agency: Paris, France, 2017.

3. International Energy Agency Key. World Energy Statistics 2018, 21st ed.; International Energy Agency: Paris, France, 2018.

4. Sims, R.E.H. Bioenergy Options for a Cleaner Environment in Developed and Developing Countries; Elsevier Science \& Technology: Oxford, UK, 2003; ISBN 9780080527949. 
5. International Energy Agency. Global Energy \& CO2 Status Report. The Latest trends in Energy and Emissions in 2017; International Energy Agency: Paris, France, 2018.

6. Slade, R.; Saunders, R.; Gross, R.; Bauen, A. Energy from Biomass: The Size of The Global Resource; UK Energy Research Center: London, UK, 2011.

7. Hornung, U.; Kruse, A.; Akgül, G. Hydrothermal Liquefaction-Upgrading. In Transformation of Biomass: Theory to Practise; Kruse, A., Ed.; John Wiley \& Sons, Ltd.: Hoboken, JN, USA, 2014; ISBN 9781119973270.

8. Balaman, S.Y. Biomass-Based Production Systems. In Decision-Making for Biomass-Based Production Chains: The Basic Concepts and Methodologies; Academic Press: Cambridge, MA, USA, 2018; pp. 25-54.

9. Doassans-Carrère, N.; Ferrasse, J.-H.; Boutin, O.; Mauviel, G.; Lédé, J. Comparative Study of Biomass Fast Pyrolysis and Direct Liquefaction for Bio-Oils Production: Products Yield and Characterizations. Energy Fuels 2014, 28, 5103-5111. [CrossRef]

10. Metsa Group. Sustainability Report. 2018. Available online: https://www.metsagroup.com/en/Documents/ Publications/Metsa-Group-sustainability-report-2018.pdf (accessed on 22 June 2020).

11. Vakkilainen, E.K.; Välimäki, E. Effect of Lignin Separation to Black Liquor and Recovery Boiler Operation. In Proceedings of the TAPPI's 2009 Engineering, Pulping, and Environmental Conference, Memphis, TN, USA, 11-14 October 2009.

12. Licella. A Bridge to a Lower Carbon Future. Available online: https://www.licella.com.au/ (accessed on 27 March 2019).

13. RenFuel. Lignin Bio Oils. Available online: https://renfuel.se/?lang=en (accessed on 27 March 2019).

14. SunCarbon. Linking the Forest and Petrochemical Industry. Available online: https://www.suncarbon.se/ (accessed on 27 March 2019).

15. Licella. Cat-HTRTM-Licella. Available online: https://www.licella.com.au/cat-htr/ (accessed on 27 March 2019).

16. Rowlands, W.N.; Humphreys, L.J.; Thew, R.W.C.; Spankie, J.A.; Uloth, V.C.; Watson, P.A.; Pudlas, M.W. Integrated Kraft Pulp Mill and Thermochemical Conversion System. 2015. Available online: https: //patents.google.com/patent/WO2016058098A1/en (accessed on 29 August 2018).

17. Licella. Pulp \& Paper-Licella. Available online: https://www.licella.com.au/pulp-paper/ (accessed on 27 March 2019).

18. RenFuel. Technology-RenFuel. Available online: https://renfuel.se/technology/?lang=en (accessed on 27 March 2019).

19. SunCarbon. Our Technology-Renewable Fuels from Lignin-SunCarbon. Available online: https: //www.suncarbon.se/technology/ (accessed on 27 March 2019).

20. SunCarbon. Membrane Pilot at Kraft Pulp Mill—SunCarbon. Available online: https://www.suncarbon.se/ 2017/02/01/membrane-pilot-at-kraft-pulp-mill/ (accessed on 27 March 2019).

21. Gollakota, A.R.K.; Kishore, N.; Gu, S. A review on hydrothermal liquefaction of biomass. Renew. Sustain. Energy Rev. 2018, 81, 1378-1392. [CrossRef]

22. Castello, D.; Pedersen, T.; Rosendahl, L. Continuous Hydrothermal Liquefaction of Biomass: A Critical Review. Energies 2018, 11, 3165. [CrossRef]

23. Kang, S.; Li, X.; Fan, J.; Chang, J. Hydrothermal conversion of lignin: A review. Renew. Sustain. Energy Rev. 2013, 27, 546-558. [CrossRef]

24. Jindal, M.K.; Jha, M.K. Hydrothermal liquefaction of wood: a critical review. Rev. Chem. Eng. $2016,32$. [CrossRef]

25. Tian, C.; Li, B.; Liu, Z.; Zhang, Y.; Lu, H. Hydrothermal liquefaction for algal biorefinery: A critical review. Renew. Sustain. Energy Rev. 2014, 38, 933-950. [CrossRef]

26. López Barreiro, D.; Ronsse, F.; Brilman, W. Hydrothermal liquefaction (HTL) of microalgae for biofuel production: State of the art review and future prospects. Biomass Bioenergy 2013, 53, 113-127.

27. Vlaskin, M.S.; Chernova, N.I.; Kiseleva, S.V.; Popel', O.S.; Zhuk, A.Z. Hydrothermal liquefaction of microalgae to produce biofuels: state of the art and future prospects. Therm. Eng. 2017, 64, 627-636. [CrossRef]

28. Cao, L.; Zhang, C.; Chen, H.; Tsang, D.C.W.; Luo, G.; Zhang, S.; Chen, J. Hydrothermal liquefaction of agricultural and forestry wastes: state-of-the-art review and future prospects. Bioresour. Technol. 2017, 245, 1184-1193. [CrossRef] [PubMed]

29. Islam, M.N.; Park, J.-H. A short review on hydrothermal liquefaction of livestock manure and a chance for Korea to advance swine manure to bio-oil technology. J. Mater. Cycles Waste Manag. 2018, 20, 1-9. [CrossRef] 
30. Ramirez, J.; Brown, R.; Rainey, T.; Ramirez, J.A.; Brown, R.J.; Rainey, T.J. A Review of Hydrothermal Liquefaction Bio-Crude Properties and Prospects for Upgrading to Transportation Fuels. Energies 2015, 8, 6765-6794. [CrossRef]

31. Biermann, C.J. Pulping Fundamentals. In Handbook of Pulping and Papermaking; Elsevier: Amsterdam, The Netherlands, 1996; ISBN1 10 012647480X. ISBN2 139780126474800.

32. International Energy Agency Black Liquor Gasification. Summary and Conclusions from the IEA Bioenergy ExCo54 Workshop; International Energy Agency: Paris, France, 2007.

33. Biermann, C.J. Kraft Spent Liquor Recovery. In Handbook Pulping Papermaking; Academic Press: Cambridge, MA, USA, 1996; pp. 101-122.

34. Sjöström, E. Wood Chemistry: Fundamentals and Applications; Academic Press: Cambridge, MA, USA, 1981; ISBN1 012647480X. ISBN2 9780126474800.

35. Chakar, F.S.; Ragauskas, A.J. Review of current and future softwood kraft lignin process chemistry. Ind. Crops Prod. 2004, 20, 131-141. [CrossRef]

36. Gellerstedt, G. Chemistry of Chemical Pulping. In Pulping Chemistry and Technology; Henriksson, G., Gellerstedt, G., Monica, E.k., Eds.; Walter de Gruyter GmbH \& Co.: Berlin, Germany, 2009; ISBN1 9783110213416. ISBN2 9783110483420. ISBN3 9783110213423.

37. Alén, R.; Niemelä, K. Characterization of Pulping Liquors. In Analytical Methods in Wood Chemistry, Pulping, and Papermaking; Alén, R., Sjöström, E., Eds.; Springer: Berlin/Heidelberg, Germany, 1999; pp. 193-231. ISBN 978-3-662-03898-7.

38. Theliander, H. Recovery of Cooking Chemicals: The Treatment and Burning of Black Liquor. In Pulping Chemistry and Technology; Ek, M., Henriksson, G., Gellerstedt, G., Eds.; Walter de Gruyter GmbH \& Co.: Berlin, Germany, 2009.

39. Kinnarinen, T.; Golmaei, M.; Jernström, E.; Häkkinen, A. Separation, treatment and utilization of inorganic residues of chemical pulp mills. J. Clean. Prod. 2016, 133, 953-964. [CrossRef]

40. Bajpai, P. Structure of Lignocellulosic Biomass. In Pretreatment of Lignocellulosic Biomass for Biofuel Production; Springer: Singapore, 2016; pp. 7-12.

41. Stokke, D.D.; Wu, Q.; Han, G.; Stevens, C.V. Introduction to Wood and Natural Fiber Composites, 1st ed.; Stokke, D.D., Wu, Q., Han, G., Stevens, C.V., Eds.; John Wiley \& Sons, Incorporate: Hoboken, NJ, USA; ISBN 9780470710913.

42. McKendry, P. Energy production from biomass (part 1): overview of biomass. Bioresour. Technol. 2002, 83, 10. [CrossRef]

43. Van de Wouwer, D.; Boerjan, W.; Vanholme, B. Plant cell wall sugars: sweeteners for a bio-based economy. Physiol. Plant. 2018, 164, 27-44. [CrossRef] [PubMed]

44. Tejado, A.; Peña, C.; Labidi, J.; Echeverria, J.M.; Mondragon, I. Physico-chemical characterization of lignins from different sources for use in phenol-formaldehyde resin synthesis. Bioresour. Technol. 2007, 98, 1655-1663. [CrossRef] [PubMed]

45. Lancefield, C.S.; Wienk, H.L.J.; Boelens, R.; Weckhuysen, B.M.; Bruijnincx, P.C.A. Identification of a diagnostic structural motif reveals a new reaction intermediate and condensation pathway in kraft lignin formation. Chem. Sci. 2018, 9, 6348-6360. [CrossRef]

46. Arkell, A.; Olsson, J.; Wallberg, O. Process performance in lignin separation from softwood black liquor by membrane filtration. Chem. Eng. Res. Des. 2014, 92, 1792-1800. [CrossRef]

47. Alekhina, M.; Ershova, O.; Ebert, A.; Heikkinen, S.; Sixta, H. Softwood kraft lignin for value-added applications: Fractionation and structural characterization. Ind. Crops Prod. 2015, 66, 220-228. [CrossRef]

48. Sjöström, E. Wood Chemistry: Fundamentals and Applications, 2nd ed.; Academic Press, Inc.: Cambridge, MA, USA, 1993.

49. Sjöström, E. Preface to the first edition. In Wood Chemistry: Fundamentals and Applications; Academic Press, Inc.: Cambridge, MA, USA, 1965; pp. xiii-xiv.

50. Demirbas, A. Thermochemical Conversion Processes. In Biofuels; Springer: London, UK, 2009; pp. 261-304. ISBN 978-1-84882-010-4.

51. Reza, M.T.; Andert, J.; Wirth, B.; Busch, D.; Pielert, J.; Lynam, J.G.; Mumme, J. Hydrothermal Carbonization of Biomass for Energy and Crop Production. Appl. Bioenergy 2014, 1. [CrossRef] 
52. Matsumura, Y. Hydrothermal Gasification of Biomass. In Recent Advances in Thermochemical Conversion of Biomass; Pandey, A., Bhaskar, T., Stöcker, M., Sukumaran, R.K., Eds.; Elsevier: Amsterdam, the Netherlands, 2015; p. 676. ISBN 978-0-444-63289-0.

53. Masek, O. Biochar in thermal and thermochemical biorefineriesdproduction of biochar as a coproduct. In Handbook of Biofuels Production; Luque, R., Lin, C., Wilson, K., Clark, J., Eds.; Woodhead Publishing: Cambridge, UK, 2016; pp. 655-671.

54. Kumar, M.; Olajire Oyedun, A.; Kumar, A. A review on the current status of various hydrothermal technologies on biomass feedstock. Renew. Sustain. Energy Rev. 2018, 81, 1742-1770. [CrossRef]

55. Susanti, R.F.; Kim, J.; Yoo, K. pung Supercritical Water Gasification for Hydrogen Production: Current Status and Prospective of High-Temperature Operation. In Supercritical Fluid Technology for Energy and Environmental Applications; Anikeev, V., Fan, M., Eds.; Elsevier: Amsterdam, The Netherlands, 2014; pp. 111-137. ISBN 9780444626967.

56. Elliott, D.C. Catalytic hydrothermal gasification of biomass. Biofuels, Bioprod. Biorefining 2008, 2, $254-265$. [CrossRef]

57. Zo, H.; Mayr, F. Stability and Performance of Ruthenium Catalysts Based on Refractory Oxide Supports in Supercritical Water Conditions. Energy Fuels 2013, 27, 4739-4747.

58. Orebom, A.; Verendel, J.J.; Samec, J.S.M. High Yields of Bio Oils from Hydrothermal Processing of Thin Black Liquor without the Use of Catalysts or Capping Agents. ACS Omega 2018, 3, 6757-6763. [CrossRef] [PubMed]

59. Sengers, J.M.H.L.; Straub, J.; Watanabe, K.; Hill, P.G. Assessment of Critical Parameter Values for $\mathrm{H}_{2} \mathrm{O}$ and $\mathrm{D}_{2}$ O. J. Phys. Chem. Ref. Data 1985, 14, 193-207. [CrossRef]

60. Wagner, W.; Pruß, A. The IAPWS Formulation 1995 for the Thermodynamic Properties of Ordinary Water Substance for General and Scientific Use. J. Phys. Chem. Ref. Data 2002, 31, 387-535. [CrossRef]

61. Kruse, A.; Dahmen, N. Water-A magic solvent for biomass conversion. J. Supercrit. Fluids 2015, 96, 36-45. [CrossRef]

62. Bühler, W.; Dinjus, E.; Ederer, H.J.; Kruse, A.; Mas, C. Ionic reactions and pyrolysis of glycerol as competing reaction pathways in near- and supercritical water. J. Supercrit. Fluids 2002, 22, 37-53. [CrossRef]

63. IAPWS Release on the Static Dielectric Constant of Ordinary Water Substance for Temperature from $238 \mathrm{~K}$ to $873 \mathrm{~K}$ and Pressures up to $1000 \mathrm{MPa}$; Erlangen, Germany. 1997. Available online: http: //www.iapws.org/relguide/Dielec.html (accessed on 22 June 2020).

64. IAPWS Release on the Ionization Constant of $\mathrm{H}_{2} \mathrm{O}$; Lucerne, Switzerland. 2007. Available online: http: //www.iapws.org/relguide/Ionization.html (accessed on 22 June 2020).

65. Sandquist, J.; Tschentscher, R.; del Alamo Serrano, G. Hydrothermal liquefaction of organic resources in biotechnology: how does it work and what can be achieved? Appl. Microbiol. Biotechnol. 2019, 103, 673-684. [CrossRef] [PubMed]

66. Jouyban, A.; Soltanpour, S.; Chan, H.-K. A simple relationship between dielectric constant of mixed solvents with solvent composition and temperature. Int. J. Pharm. 2004, 269, 353-360. [CrossRef]

67. Hodes, M.; Marrone, P.A.; Hong, G.T.; Smith, K.A.; Tester, J.W. Salt precipitation and scale control in supercritical water oxidation-Part A: fundamentals and research. J. Supercrit. Fluids 2004, 29, 265-288. [CrossRef]

68. Valyashko, V. Phase equilibria of water-salt systems at high temperatures and pressures. In Aqueous Systems at Elevated Temperatures and Pressures; Fernandez-Prini, R., Harvey, A.H., Palmer, D.A., Eds.; Elsevier: Amsterdam, The Netherlands, 2004; pp. 597-641. ISBN 9780080471990.

69. Valyashko, V.M. Phase Equilibria in Binary and Ternary Hydrothermal Systems. In Hydrothermal Experimental Data; John Wiley \& Sons, Ltd.: Chichester, UK, 2008; pp. 1-133.

70. Rumyantsev, V.N. Selection of mineralizers in the hydrothermal synthesis and growth of crystals. Sov. Phys. Crystallogr. 1977, 22, 610-613.

71. Wang, R.; Deplazes, R.; Guo, L.; Vogel, F.; Baudouin, D. Continuous extraction of black liquor salts under hydrothermal conditions, in preparation.

72. Ihara, K.; Ueda, H.; Sue, K.; Nonaka, T.; Arai, K. Decomposition of Sodium Thiosulfate and Sodium Thiocyanate in Supercritical Water. J. Japan Inst. Energy 2006, 85, 126-134. [CrossRef]

73. Schubert, M.; Regler, J.W.; Vogel, F. Continuous salt precipitation and separation from supercritical water. Part 2. Type 2 salts and mixtures of two salts. J. Supercrit. Fluids 2010, 52, 113-124. [CrossRef] 
74. Schubert, M.; Aubert, J.; Müller, J.B.; Vogel, F. Continuous salt precipitation and separation from supercritical water. Part 3: Interesting effects in processing type 2 salt mixtures. J. Supercrit. Fluids 2012, 61, 44-54. [CrossRef]

75. Kruse, A.; Forchheim, D.; Gloede, M.; Ottinger, F.; Zimmermann, J. Brines in supercritical biomass gasification: 1. Salt extraction by salts and the influence on glucose conversion. J. Supercrit. Fluids 2010, 53, 64-71. [CrossRef]

76. Makaev, S.V.; Bitokhov, T.M.; Kravchuk, K.G.; Urusova, M.A.; Valyashko, V.M. Salt deposition from hydrothermal solutions in a flow reactor. Russ. J. Phys. Chem. B 2011, 5, 1045-1055.

77. Schubert, M.; Müller, J.B.; Vogel, F. Continuous hydrothermal gasification of glycerol mixtures: Effect of glycerol and its degradation products on the continuous salt separation and the enhancing effect of $\mathrm{K}_{3} \mathrm{PO}_{4}$ on the glycerol degradation. J. Supercrit. Fluids 2014, 95, 364-372. [CrossRef]

78. De Blasio, C.; De Gisi, S.; Molino, A.; Simonetti, M.; Santarelli, M.; Björklund-Sänkiaho, M. Concerning operational aspects in supercritical water gasification of kraft black liquor. Renew. Energy 2019, 130, 891-901. [CrossRef]

79. Voisin, T.; Erriguible, A.; Ballenghien, D.; Mateos, D.; Kunegel, A.; Cansell, F.; Aymonier, C. Solubility of inorganic salts in sub- and supercritical hydrothermal environment: Application to SCWO processes. J. Supercrit. Fluids 2017, 120, 18-31. [CrossRef]

80. Khan, M.; Rogak, S. Solubility of Na2SO4, Na2CO3 and their mixture in supercritical water. J. Supercrit. Fluids 2004, 30, 359-373. [CrossRef]

81. Príkopský, K.; Wellig, B.; von Rohr, P.R. SCWO of salt containing artificial wastewater using a transpiring-wall reactor: Experimental results. J. Supercrit. Fluids 2007, 40, 246-257. [CrossRef]

82. Elliott, D.C.; Hart, T.R.; Schmidt, A.J.; Neuenschwander, G.G.; Rotness, L.J.; Olarte, M.V.; Zacher, A.H.; Albrecht, K.O.; Hallen, R.T.; Holladay, J.E. Process development for hydrothermal liquefaction of algae feedstocks in a continuous- fl ow reactor. ALGAL 2013, 2, 445-454. [CrossRef]

83. Nakamura, A.; Kiyonaga, E.; Yamamura, Y.; Shimizu, Y.; Minowa, T.; Noda, Y.; Matsumura, Y. Gasification of Catalyst-Suspended Chicken Manure in Supercritical Water. J. Chem. Eng. JAPAN 2008, 41, 433-440. [CrossRef]

84. Elliott, D.C.; Butner, R.S.; Neuenschwander, G.G.; Zacher, A.H.; Hart, T.R. Methods and Apparatus for Catalytic Hydrothermal Gasification of Biomass. 2008. Available online: https:/patents.google.com/patent/ US8241605/3Den (accessed on 3 May 2019).

85. Antal, M.J.; Allen, S.G.; Schulman, D.; Xu, X.; Divilio, R.J. Biomass Gasification in Supercritical Water. Ind. Eng. Chem. Res. 2000, 39, 4040-4053. [CrossRef]

86. Marrone, P.A.; Hodes, M.; Smith, K.A.; Tester, J.W. Salt precipitation and scale control in supercritical water oxidation — part B: commercial / full-scale applications. J. Supercrit. Fluids 2004, 29, 289-312. [CrossRef]

87. Peng, G.; Zambrano Varela, R.; Reid Dick, G.; Juillard, F.; Bertschy, L.; De Boni, E.; Vogel, F.; Varela, R.Z.; Dick, G.R.; Juillard, F.; et al. Continuous Phosphorus Recovery and Biogas Generation from Sewage Sludge by Hydrothermal Processing, in preparation. Nat. Energy 2018.

88. Favrat, D.; MARECHAL, F.; Ensinas, A.V.; Mian, A. Apparatus for Salt Separation Under Supercritical Water Conditions. U.S. Patent WO2016113685A1, 16 January 2015.

89. Elliott, D.C.; Biller, P.; Ross, A.B.; Schmidt, A.J.; Jones, S.B. Hydrothermal liquefaction of biomass: Developments from batch to continuous process. Bioresour. Technol. 2015, 178, 147-156. [CrossRef]

90. Schubert, M.; Regler, J.W.; Vogel, F. Continuous salt precipitation and separation from supercritical water. Part 1: Type 1 salts. J. Supercrit. Fluids 2010, 52, 99-112. [CrossRef]

91. Reimer, J.; Peng, G.; Viereck, S.; De Boni, E.; Breinl, J.; Vogel, F. A novel salt separator for the supercritical water gasification of biomass. J. Supercrit. Fluids 2016, 117, 113-121. [CrossRef]

92. Viereck, S.; Jovanovic, Z.R.; Haselbacher, A.; Steinfeld, A. Investigation of Na2SO4 removal from a supercritical aqueous solution in a dip-tube salt separator. J. Supercrit. Fluids 2018, 133, 146-155. [CrossRef]

93. Lyckeskog, H.N. Hydrothermal Liquefaction of Lignin into Bio-Oil Influence of the Reaction Conditions and Stability of the Bio-Oil Produced; Chalmers University of Technology: Gothenburg, Sweden, 2016.

94. Basu, P. Hydrothermal Conversion of Biomass. In Biomass Gasification, Pyrolysis and Torrefaction-Practical Design and Theory; Academic Press: Cambridge, MA, USA, 2018; pp. 331-372.

95. Sasaki, M.; Goto, M. Recovery of phenolic compounds through the decomposition of lignin in near and supercritical water. Chem. Eng. Process. Process Intensif. 2008, 47, 1609-1619. 
96. Schuler, J.; Hornung, U.; Dahmen, N.; Sauer, J. Lignin from bark as a resource for aromatics production by hydrothermal liquefaction. GCB Bioenergy 2019, 11, 218-229. [CrossRef]

97. Yong, T.L.-K.; Matsumura, Y. Kinetic Analysis of Lignin Hydrothermal Conversion in Sub- and Supercritical Water. Ind. Eng. Chem. Res. 2013, 52, 5626-5639. [CrossRef]

98. Yong, T.L.-K.; Matsumura, Y. Reaction Kinetics of the Lignin Conversion in Supercritical Water. Ind. Eng. Chem. Res. 2012, 51, 11975-11988. [CrossRef]

99. Forchheim, D. Optimisation of the Reaction Parameters in a Batch Reactor and a CSTR for the Recovery of Phenol from Hydrothermal Biomass Liquefaction. 2014. Available online: https://publikationen.bibliothek. kit.edu/1000042417 (accessed on 27 August 2018).

100. Forchheim, D.; Hornung, U.; Kruse, A.; Sutter, T. Kinetic Modelling of Hydrothermal Lignin Depolymerisation. Waste Biomass Valorization 2014, 5, 985-994. [CrossRef]

101. Tran, K.-Q. Fast hydrothermal liquefaction for production of chemicals and biofuels from wet biomass The need to develop a plug-flow reactor. Bioresour. Technol. 2016, 213, 327-332. [CrossRef]

102. Toor, S.S.; Rosendahl, L.; Rudolf, A. Hydrothermal liquefaction of biomass: A review of subcritical water technologies. Energy 2011, 36, 2328-2342. [CrossRef]

103. Elliott, D.C.; Hallen, R.T.; Sealock, L.J. Aqueous catalyst systems for the water-gas shift reaction. 2. Mechanism of basic catalysis. Ind. Eng. Chem. Prod. Res. Dev. 1983, 22, 431-435. [CrossRef]

104. Elliott, D.C.; Sealock, L.J. Aqueous catalyst systems for the water-gas shift reaction. 1. Comparative catalyst studies. Ind. Eng. Chem. Prod. Res. Dev. 1983, 22, 426-431. [CrossRef]

105. Tomani, P. The lignoboost process. Cellul. Chem. Technol. 2010, 44, 53.

106. Lee, H.; Jae, J.; Ha, J.-M.; Suh, D.J. Hydro- and solvothermolysis of kraft lignin for maximizing production of monomeric aromatic chemicals. Bioresour. Technol. 2016, 203, 142-149. [CrossRef]

107. Nguyen, T.D.H.; Maschietti, M.; Åmand, L.-E.; Vamling, L.; Olausson, L.; Andersson, S.-I.; Theliander, H. The effect of temperature on the catalytic conversion of Kraft lignin using near-critical water. Bioresour. Technol. 2014, 170, 196-203. [CrossRef] [PubMed]

108. Sugano, M.; Takagi, H.; Hirano, K.; Mashimo, K. Hydrothermal liquefaction of plantation biomass with two kinds of wastewater from paper industry. J. Mater. Sci. 2008, 43, 2476-2486. [CrossRef]

109. Cheng, S.; Wilks, C.; Yuan, Z.; Leitch, M.; Xu, C. (Charles) Hydrothermal degradation of alkali lignin to bio-phenolic compounds in sub/supercritical ethanol and water-ethanol co-solvent. Polym. Degrad. Stab. 2012, 97, 839-848. [CrossRef]

110. Belkheiri, T.; Vamling, L.; Dieu, T.; Lyckeskog, H.; Maschietti, M.; Olausson, L.; Andersson, S.-I.; Åmand, L.-E.; Theliander, H. Kraft Lignin Depolymerization in Near-Critical Water: Effect of Changing Co-Solvent. Cellulose Chem. Technol. 2014, 48, 813-818.

111. Arturi, K.R.; Strandgaard, M.; Nielsen, R.P.; Søgaard, E.G.; Maschietti, M. Hydrothermal liquefaction of lignin in near-critical water in a new batch reactor: Influence of phenol and temperature. J. Supercrit. Fluids 2017, 123, 28-39. [CrossRef]

112. Belkheiri, T.; Andersson, S.-I.; Mattsson, C.; Olausson, L.; Theliander, H.; Vamling, L. Hydrothermal Liquefaction of Kraft Lignin in Subcritical Water: Influence of Phenol as Capping Agent. Energy Fuels 2018, 32, 5923-5932. [CrossRef]

113. Belkheiri, T.; Andersson, S.-I.; Mattsson, C.; Olausson, L.; Theliander, H.; Vamling, L. Hydrothermal liquefaction of kraft lignin in sub-critical water: The Influence of the Sodium and Potassium Fraction. Biomass Convers. Biorefinery 2018, 8, 585-595. [CrossRef]

114. Nguyen, T.D.H.; Maschietti, M.; Belkheiri, T.; Åmand, L.E.; Theliander, H.; Vamling, L.; Olausson, L.; Andersson, S.I. Catalytic depolymerisation and conversion of Kraft lignin into liquid products using near-critical water. J. Supercrit. Fluids 2014, 86, 67-75. [CrossRef]

115. Belkheiri, T.; Mattsson, C.; Andersson, S.-I.; Olausson, L.; Åmand, L.-E.; Theliander, H.; Vamling, L. Effect of $\mathrm{pH}$ on Kraft Lignin Depolymerisation in Subcritical Water. Energy Fuels 2016, 30, 4916-4924.

116. Solantausta, Y.; Anacker, C.; Armbruster, U.; Meier, D.; Appelt, J.; Martin, A.; Strüven, J.O.; Eidam, P.; Mirodatos, C.; Schuurman, Y.; et al. Liquid Fuels from Lignin by Hydrothermal Liquefaction and Deoxygenation (LIGNOHTL). Final Report. 2018. Available online: https://forestvalue.org/wp-content/ uploads/2018/07/wwnet_jc4_final_reporting_lignoHTL.pdf (accessed on 3 May 2019).

117. Schuler, J.; Hornung, U.; Kruse, A.; Dahmen, N.; Sauer, J. Hydrothermal Liquefaction of Lignin. J. Biomater. Nanobiotechnol. 2017, 08, 96-108. [CrossRef] 
118. Watanabe, M.; Sato, T.; Inomata, H.; Smith, R.L.; Arai, K.; Kruse, A.; Dinjus, E. Chemical Reactions of C 1 Compounds in Near-Critical and Supercritical Water. Chem. Rev. 2004, 104, 5803-5822. [CrossRef] [PubMed]

119. Dieu Huyen, T.; Maschietti, M.; Dieu Huyen Nguyen, T.; Belkheiri, T.; Åmand, L.-E.; Theliander, H.; Vamling, L.; Olausson, L.; Andersson, S.-I. Catalytic hydrothermal conversion of LignoBoost Kraft lignin for the production of bio-oil and aromatic chemicals. In Proceedings of the International Chemical Recovery Conference, Tampere, Finland, 8-13 June 2014; Nieminen, M., Lampinen, P., Eds.; Finnish Recovery Boiler Committee: Tampere, Finland, 2014; Volume 2, pp. 252-261.

120. Välimäki, A. Mustalipeän hydrotermisen nesteytyksen vaikutus bioöljyn laatuun (Improving bio-oil quality in hydrothermal liquefaction of black liquor). Master's Thesis, Aalto University, Aalto, Finland, 2017.

121. Sricharoenchaikul, V. Assessment of black liquor gasification in supercritical water. Bioresour. Technol. 2009, 100, 638-643. [CrossRef] [PubMed]

122. Tran, H.N.; Barham, D.; Reeve, D.W. Chloride and Potassium in the Kraft Recovery Cycle: A Practical Guide. Pulp Pap. Can. Ont. 1990, 91, 185-190.

123. Minowa, T.; Zhen, F.; Ogi, T. Cellulose decomposition in hot-compressed water with alkali or nickel catalyst. J. Supercrit. Fluids 1998, 13, 253-259. [CrossRef]

124. Melin, K.; Välimäki, A.; Oasmaa, A.; Lehtonen, J. The Effect of Hydrothermal Liquefaction of Black Liquor in Bio-oil Quality. Eur. Biomass Conf. Exhib. Proc. 2019, 1144-1145.

125. Peng, C.; Zhang, G.; Han, J.; Li, X. Hydrothermal conversion of lignin and black liquor for phenolics with the aids of alkali and hydrogen donor. Carbon Resour. Convers. 2019, 2, 141-150. [CrossRef]

126. Osada, M.; Hiyoshi, N.; Sato, O.; Arai, K.; Shirai, M. Effect of Sulfur on Catalytic Gasification of Lignin in Supercritical Water. Energy Fuels 2007, 21, 1400-1405.

127. Al'myasheva, O.V.; Korytkova, E.N.; Maslov, A.V.; Gusarov, V. Preparation of Nanocrystalline Alumina under Hydrothermal Conditions. Inorg Mater 2005, 41, 460-467. [CrossRef]

128. Kauppi, E.I.; Honkala, K.; Krause, A.O.I.; Kanervo, J.M.; Lefferts, L. ZrO2 Acting as a Redox Catalyst. Top. Catal. 2016, 59, 823-832. [CrossRef]

129. Forchheim, D.; Hornung, U.; Kempe, P.; Kruse, A.; Steinbach, D. Influence of RANEY Nickel on the Formation of Intermediates in the Degradation of Lignin. Int. J. Chem. Eng. 2012, 2012, 589749. [CrossRef]

130. Hupa, M. Recovery boiler chemical principles. TAPPI Kraft Recover. Course 2007, 2007, 2.

131. Buncel, E.; Stairs, R.A. Solvent Effects in Chemistry; Wiley Publishing: Hoboken, NJ, USA, 2015; ISBN 9781119030980.

132. Isa, K.M.; Abdullah, T.A.T.; Ali, U.F.M. Hydrogen donor solvents in liquefaction of biomass: A review. Renew. Sustain. Energy Rev. 2018, 81, 1259-1268. [CrossRef]

133. Okuda, K.; Umetsu, M.; Takami, S.; Adschiri, T. Disassembly of lignin and chemical recovery-Rapid depolymerization of lignin without char formation in water-phenol mixtures. Fuel Process. Technol. 2004, 85, 803-813. [CrossRef]

134. Liu, Z.; Zhang, F.-S. Effects of various solvents on the liquefaction of biomass to produce fuels and chemical feedstocks. Energy Convers. Manag. 2008, 49, 3498-3504. [CrossRef]

135. Wu, X.Y.; Lü, X.Y. Hydrolysis kinetics of benzyl phenyl ether in high temperature liquid water. Chin. Chem. Lett. 2011, 22, 733-737. [CrossRef]

136. Sasaki, M.; Goto, M. Conversion of biomass model compound under hydrothermal conditions using batch reactor. Fuel 2009, 88, 1656-1664. [CrossRef]

137. Wu, X.; Fu, J.; Lu, X. Kinetics and Mechanism of Hydrothermal Decomposition of Lignin Model Compounds. Ind. Eng. Chem. Res. 2013, 52, 5016-5022. [CrossRef]

138. Sato, T.; Sekiguchi, G.; Saisu, M.; Watanabe, M.; Adschiri, T.; Arai, K. Dealkylation and Rearrangement Kinetics of 2-Isopropylphenol in Supercritical Water. Ind. Eng. Chem. Res. 2002, 41, 3124-3130. [CrossRef]

139. Penninger, J.M.; Kersten, R.J.; Baur, H.C. Reactions of diphenylether in supercritical water-mechanism and kinetics. J. Supercrit. Fluids 1999, 16, 119-132. [CrossRef]

140. Schuler, J. Hydrothermal Liquefaction of Lignin. Ph.D. Thesis, Karlsruhe Institute of Technology, Karlsruhe, Germany, 2019.

141. Timko, M.T.; Ghoniem, A.F.; Green, W.H. Upgrading and desulfurization of heavy oils by supercritical water. J. Supercrit. Fluids 2015, 96, 114-123. [CrossRef]

142. Fan, H.; Zhang, Y.; Lin, Y. The catalytic effects of minerals on aquathermolysis of heavy oils. Fuel 2004, 83, 2035-2039. [CrossRef] 
143. Scott, D.; Radlein, D.; Piskorz, J.; Majerski, P.; DeBruijn, T.J. Upgrading of bitumen in supercritical fluids. Fuel 2001, 80, 1087-1099. [CrossRef]

144. Katritzky, A.R.; Nichols, D.A.; Siskin, M.; Murugan, R.; Balasubramanian, M. Reactions in High-Temperature Aqueous Media. Chem. Rev. 2001, 101, 837-892. [CrossRef]

145. Schutyser, W.; Renders, T.; Van Den Bosch, S.; Koelewijn, S.F.; Beckham, G.T.; Sels, B.F. Chemicals from lignin: An interplay of lignocellulose fractionation, depolymerisation, and upgrading. Chem. Soc. Rev. 2018, 47, 852-908. [CrossRef]

146. Katritzky, A.R.; Murugan, R.; Balasubramanian, M.; Greenhill, J.V.; Siskin, M.; Brons, G. Aqueous High-Temperature Chemistry of Carbo-And Heterocycles 161 Model Sulfur Compounds: A Study of Hydrogen Sulfide Generation. Energy Fuels 1991, 823-834. [CrossRef]

147. Yang, B.; Tian, S.; Zhao, S. A study of thermal decomposition of alkanethiols in pressure reactor. Fuel Process. Technol. 2006, 87, 673-678. [CrossRef]

148. Patwardhan, P.R.; Timko, M.T.; Class, C.A.; Bonomi, R.E.; Kida, Y.; Hernandez, H.H.; Tester, J.W.; Green, W.H. Supercritical water desulfurization of organic sulfides is consistent with free-radical kinetics. Energy Fuels 2013, 27, 6108-6117. [CrossRef]

149. Vogelaar, B.M.; Makkee, M.; Moulijn, J.A. Applicability of supercritical water as a reaction medium for desulfurisation and demetallisation of gasoil. Fuel Process. Technol. 1999, 61, 265-277. [CrossRef]

150. Katritzky, A.R.; Barcock, R.A.; Balasubramanian, M.; Greenhill, J.V.; Siskin, M.; Olmstead, W.N. Aqueous High-Temperature Chemistry of Carbo- and Heterocycles. 21. Reactions of Sulfur-Containing Compounds in Supercritical Water at $460^{\circ} \mathrm{C}$. Energy Fuels 1994, 8, 498-506. [CrossRef]

151. Kida, Y.; Class, C.A.; Concepcion, A.J.; Timko, M.T.; Green, W.H. Combining experiment and theory to elucidate the role of supercritical water in sulfide decomposition. Phys. Chem. Chem. Phys. 2014, 16, 9220-9228. [CrossRef] [PubMed]

152. Lewan, M.D. Sulphur-radical control on petroleum formation rates. Nature 1998, 391, 164-166. [CrossRef]

153. Katritzky, A.R.; Murugan, R.; Siskin, M. Aqueous high-temperature chemistry of carbo- and heterocycles. 15. Aquathermolysis of arenethiols and aryl sulfides in the presence and absence of sodium bisulfite. Energy Fuels 1990, 4, 577-584. [CrossRef]

154. Goldstein, T.P.; Aizenshtat, Z. Thermochemical sulfate reduction a review. J. Therm. Anal. 1994, 42, $241-290$. [CrossRef]

155. Zhang, T.; Amrani, A.; Ellis, G.S.; Ma, Q.; Tang, Y. Experimental investigation on thermochemical sulfate reduction by $\mathrm{H}_{2} \mathrm{~S}$ initiation. Geochim. Cosmochim. Acta 2008, 72, 3518-3530. [CrossRef]

156. Yuan, S.; Chou, I.; Burruss, R.C.; Wang, X. Disproportionation and thermochemical sulfate reduction reactions in $\mathrm{S}-\mathrm{H}_{2} \mathrm{O}-\mathrm{CH}_{4}$ and $\mathrm{S}-\mathrm{D}_{2} \mathrm{O}-\mathrm{CH}_{4}$ systems from 200 to $340{ }^{\circ} \mathrm{C}$ at elevated pressures. Geochimica Cosmochimica Acta 2013, 118, 263-275. [CrossRef]

157. Thom, J.; Anderson, G.M. The role of thermochemical sulfate reduction in the origin of Mississippi Valley-type deposits. I. Experimental results. Geofluids 2008, 16-26. [CrossRef]

158. Meshoulam, A.; Ellis, G.S.; Said Ahmad, W.; Deev, A.; Sessions, A.L.; Tang, Y.; Adkins, J.F.; Liu, J.; Gilhooly, W.P.; Aizenshtat, Z.; et al. Study of thermochemical sulfate reduction mechanism using compound specific sulfur isotope analysis. Geochim. Cosmochim. Acta 2016, 188, 73-92. [CrossRef]

159. Vaughan, D.J. Sulfide Mineralogy and Geochemistry: Introduction and Overview. Rev. Mineral. Geochemistry 2006, 61, 1-5. [CrossRef]

160. Xia, X.; Ellis, G.S.; Ma, Q.; Tang, Y. Compositional and stable carbon isotopic fractionation during non-autocatalytic thermochemical sulfate reduction by gaseous hydrocarbons. Geochim. Cosmochim. Acta 2014, 139, 472-486. [CrossRef]

161. Zhang, T.; Ellis, G.S.; Ma, Q.; Amrani, A.; Tang, Y. Kinetics of uncatalyzed thermochemical sulfate reduction by sulfur-free paraffin. Geochim. Cosmochim. Acta 2012, 96, 1-17. [CrossRef]

162. Amrani, A.; Zhang, T.; Ma, Q.; Ellis, G.S.; Tang, Y. The role of labile sulfur compounds in thermochemical sulfate reduction. Geochim. Cosmochim. Acta 2008, 72, 2960-2972. [CrossRef]

163. Ma, Q.; Ellis, G.S.; Amrani, A.; Zhang, T.; Tang, Y. Theoretical study on the reactivity of sulfate species with hydrocarbons. Geochim. Cosmochim. Acta 2008, 72, 4565-4576. [CrossRef]

164. Ellis, A.; Giggenbach, W. Hydrogen sulphide ionization and sulphur hydrolysis in high temperature solution. Geochim. Cosmochim. Acta 1971, 35, 247-260. [CrossRef] 
165. Oana, S.; Ishikawa, H. Sulfur isotopic fractionation between sulfur and sulfuric acid in the hydrothermal solution of sulfur dioxide. Geochem. J. 1966, 1, 45-50. [CrossRef]

166. Yakaboylu, O.; Harinck, J.; Gerton Smit, K.G.; de Jong, W. Supercritical water gasification of manure: A thermodynamic equilibrium modeling approach. Biomass and Bioenergy 2013, 59, 253-263. [CrossRef]

167. Meier, D.; Windt, M. Analysis of Bio-Oils. In Transformation of Biomass: Theory to Practice; Hornung, A., Ed.; John Wiley \& Sons, Incorporate: Hoboken, NJ, USA, 2014; pp. 227-256. ISBN 9781118693643.

168. Schobert, H. Composition, classification, and properties of petroleum. In Chemistry of Fossil Fuels and Biofuels; Cambridge University Press: Cambridge, UK, 2013; pp. 174-191.

169. Demirbas, A.; Alidrisi, H.; Balubaid, M.A. API gravity, sulfur content, and desulfurization of crude oil. Pet. Sci. Technol. 2015, 33, 93-101. [CrossRef]

170. Funkenbusch, L.T.; Mullins, M.E.; Vamling, L.; Belkhieri, T.; Srettiwat, N.; Winjobi, O.; Shonnard, D.R.; Rogers, T.N. Technoeconomic assessment of hydrothermal liquefaction oil from lignin with catalytic upgrading for renewable fuel and chemical production. Wiley Interdiscip. Rev. Energy Environ. 2019, 8, e319. [CrossRef]

171. Ong, B.H.Y.; Walmsley, T.G.; Atkins, M.J.; Walmsley, M.R.W. Hydrothermal liquefaction of Radiata Pine with Kraft black liquor for integrated biofuel production. J. Clean. Prod. 2018, 199, 737-750. [CrossRef]

172. U.S. Energy Information Administration Spot Prices for Crude Oil and Petroleum Products. Available online: https://www.eia.gov/dnav/pet/pet_pri_spt_s1_m.htm (accessed on 2 April 2019).

173. Pedersen, T.H.; Hansen, N.H.; Pérez, O.M.; Cabezas, D.E.V.; Rosendahl, L.A. Renewable hydrocarbon fuels from hydrothermal liquefaction: A techno-economic analysis. Biofuels, Bioprod. Biorefining 2018, 12, $213-223$. [CrossRef]

174. Magdeldin, M.; Kohl, T.; Järvinen, M. Techno-economic assessment of the by-products contribution from non-catalytic hydrothermal liquefaction of lignocellulose residues. Energy 2017, 137, 679-695. [CrossRef]

175. Tews, I.J.; Zhu, Y.; Drennan, C.; Elliott, D.C.; Snowden-Swan, L.J.; Onarheim, K.; Solantausta, Y.; Beckman, D. Biomass Direct Liquefaction Options. TechnoEconomic and Life Cycle Assessment; Pacific Northwest National Lab: Richland, WA, USA, 2014.

(C) 2020 by the authors. Licensee MDPI, Basel, Switzerland. This article is an open access article distributed under the terms and conditions of the Creative Commons Attribution (CC BY) license (http://creativecommons.org/licenses/by/4.0/). 